ORNL/TM-2004/297

\title{
Summary of Travel Trends 2001 National Household Travel Survey
}

December 2004 


\title{
DOCUMENT AVAILABILITY
}

Reports produced after January 1, 1996, are generally available free via the U.S. Department of Energy (DOE) Information Bridge.

Web site http://www.osti.gov/bridge

Reports produced before January 1, 1996, may be purchased by members of the public from the following source.

\author{
National Technical Information Service \\ 5285 Port Royal Road \\ Springfield, VA 22161 \\ Telephone 703-605-6000 (1-800-553-6847) \\ TDD 703-487-4639 \\ Fax703-605-6900 \\ E-mail info@ntis.fedworld.gov \\ Web site http://www.ntis.gov/support/ordernowabout.htm
}

Reports are available to DOE employees, DOE contractors, Energy Technology Data Exchange (ETDE) representatives, and International Nuclear Information System (INIS) representatives from the following source.

Office of Scientific and Technical Information

P.O. Box 62

Oak Ridge, TN 37831

Telephone 865-576-8401

Fax865-576-5728

E-mail reports@adonis.osti.gov

Web site http://www.osti.gov/contact.html

This report was prepared as an account of work sponsored by an agency of the United States Government. Neither the United States government nor any agency thereof, nor any of their employees, makes any warranty, express or implied, or assumes any legal liability or responsibility for the accuracy, completeness, or usefulness of any information, apparatus, product, or process disclosed, or represents that its use would not infringe privately owned rights. Reference herein to any specific commercial product, process, or service by trade name, trademark, manufacturer, or otherwise, does not necessarily constitute or imply its endorsement, recommendation, or favoring by the United States Government or any agency thereof. The views and opinions of authors expressed herein do not necessarily state or reflect those of the United States Government or any agency thereof. 


\title{
Summary of Travel Trends 2001 National Household Travel Survey
}

December 2004

\author{
Patricia S. Hu \\ Center for Transportation Analysis \\ Oak Ridge National Laboratory \\ and \\ Timothy R. Reuscher \\ MacroSys Research and Technology
}

\author{
Prepared for \\ U.S. DEPARTMENT OF TRANSPORTATION \\ Federal Highway Administration \\ Washington, D.C. 20590
}

Prepared by

OAK RIDGE NATIONAL LABORATORY

Oak Ridge, Tennessee 37831-6285

managed by

UT-BATTELLE, LLC

for the

U.S. DEPARTMENT OF ENERGY

under contract DE-AC05-00OR22725 



\section{TABLE OF CONTENTS}

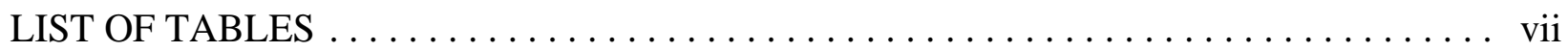

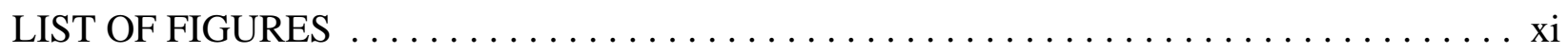

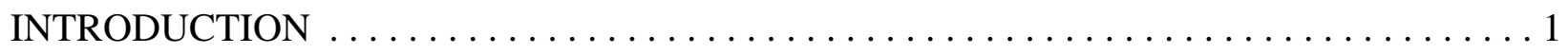

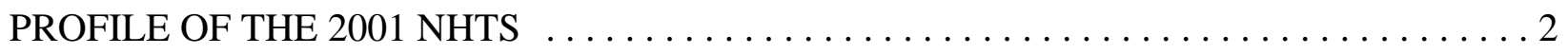

IMPROVEMENTS IN THE NPTS/NHTS SERIES $\ldots \ldots \ldots \ldots \ldots \ldots \ldots \ldots \ldots \ldots$

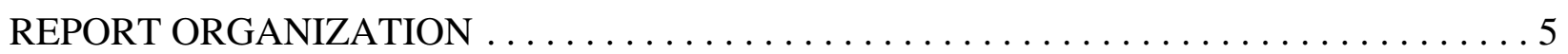

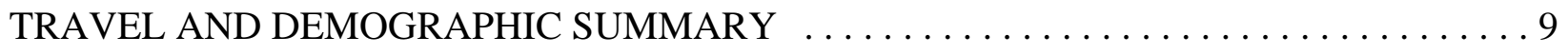

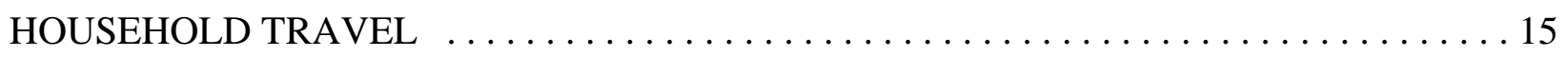

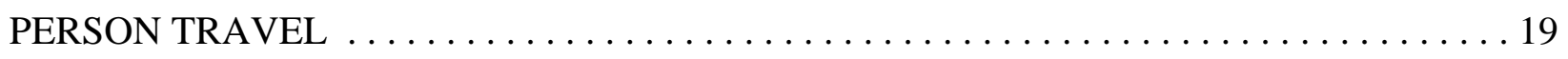

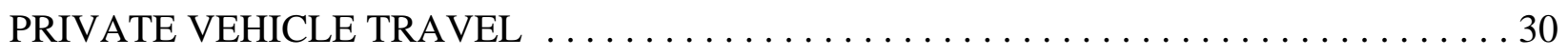

VEHICLE AVAILABILITY AND UTILIZATION $\ldots \ldots \ldots \ldots \ldots \ldots \ldots \ldots \ldots \ldots \ldots \ldots$

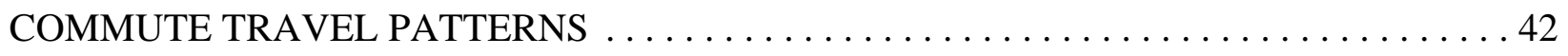

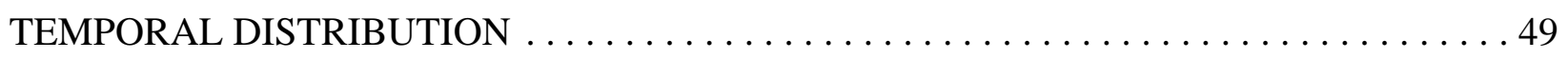

TRAVEL BEHAVIOR OF SUB-POPULATIONS $\ldots \ldots \ldots \ldots \ldots \ldots \ldots \ldots \ldots \ldots \ldots \ldots \ldots \ldots \ldots$

TRAVEL CONCEPTS AND GLOSSARY OF TERMS $\ldots \ldots \ldots \ldots \ldots \ldots \ldots \ldots$ G-1

APPENDIX 1. SELECTED TABLES INCLUDING TRAVEL OF INDIVIDUALS

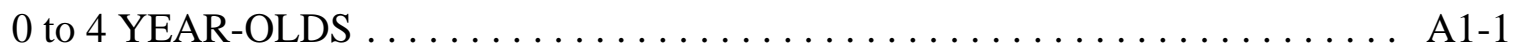

APPENDIX 2. KEY CHANGES IN THE 2001 NHTS SURVEY METHODOLOGY

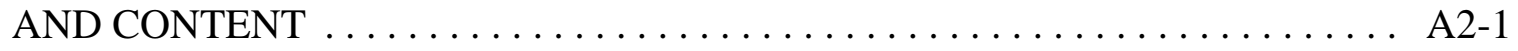

APPENDIX 3. ADJUSTMENT OF 1990 TRAVEL DATA $\ldots \ldots \ldots \ldots \ldots \ldots$ A3-1

APPENDIX 4. SELECTED STANDARD ERROR TABLES $\ldots \ldots \ldots \ldots \ldots \ldots \ldots$ A4-1 
APPENDIX 5. DIFFERENCES IN METROPOLITAN AREA DEFINITIONS

BETWEEN 1983 AND 1990 NPTS A5-1 


\section{LIST OF TABLES}

\section{Travel and Demographic Summary}

Table 1. Summary Statistics on Demographic Characteristics and Total Travel, 1969, 1977, 1983, 1990, and 1995 NPTS, and 2001 NHTS . . . . . . . . . 9

Table 2 Summary of Demographic Trends, 1969, 1977, 1983, 1990,

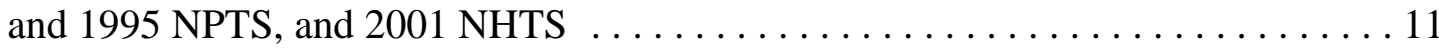

Table 3. Summary of Travel Trends, 1969, 1977, 1983, 1990,

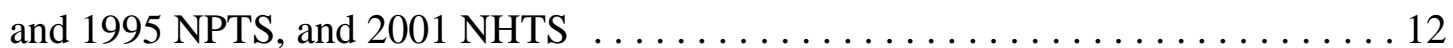

Table 4. Comparison of Survey Variables with Other Sources . . . . . . . . . . . . . . 14

\section{Household Travel}

Table 5. Average Annual PMT, Person Trips and Trip Length by Trip Purpose, 1983, 1990, and 1995 NPTS, and 2001 NHTS . . . . . . . . . . . . . 15

Table 6. Average Annual VMT, Vehicle Trips and Trip Length by Selected Trip Purposes, 1969, 1977, 1983, 1990, and 1995 NPTS, and 2001 NHTS . . . . . . . . . 16

Table 7. Average Annual Person Trips per Household by Mode of Transportation and MSA Size, 1977, 1983, 1990, and 1995 NPTS, and 2001 NHTS . . . . . . . 17

Table 8. Person Trips per Household by Household Income, 1983, 1990,

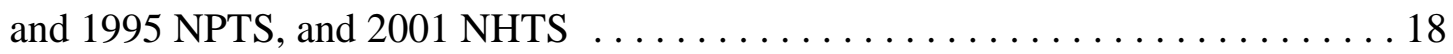

\section{Person Travel}

Table 9. Total Person Trips by Mode of Transportation and Trip Purpose, Adjusted 1990 and 1995 NPTS, and 2001 NHTS . . . . . . . . . . . . . . 19

Table 10. Person Trips per Person by Trip Purpose and Gender, Adjusted 1990 and 1995 NPTS, and 2001 NHTS . . . . . . . . . . . . . . 20

Table 11. Daily Trip Rates per Person by Trip Purpose, 1977, 1983, 1990,

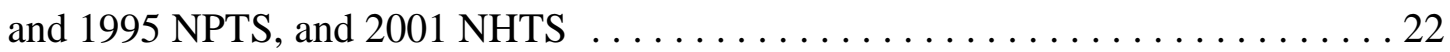

Table 12. Distribution of Daily Person Miles of Travel per Person by Mode of Transportation and Trip Purpose, Adjusted 1990 and 1995 NPTS, and 2001 NHTS 23

Table 13. Average Daily Person Trips per Person by Age and Gender,

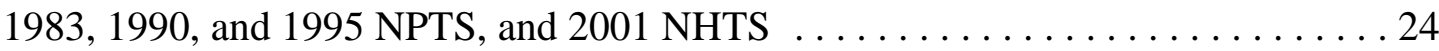


Table 14. Average Daily Person Miles of Travel per Person by Age and Gender,

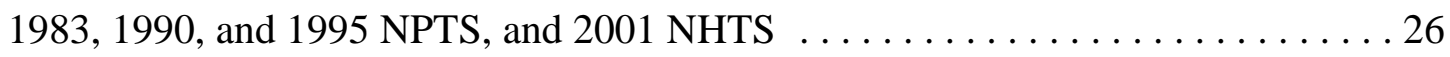

\section{Private Vehicle Travel}

Table 15. Average Time Spent Driving a Private Vehicle in a Typical Day by MSA Size, Adjusted 1990 and 1995 NPTS, and 2001 NHTS . . . . . . . . . . . . 30

Table 16. Average Vehicle Occupancy for Selected Trip Purposes, 1977, 1983, 1990, and 1995 NPTS, and 2001 NHTS . . . . . . . . . . 31

\section{Vehicle Availability and Utilization}

Table 17. Availability of Household Vehicles, 1969, 1977, 1983, 1990,

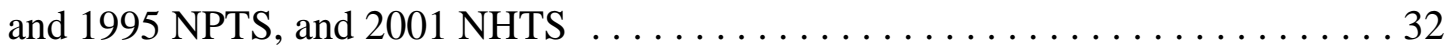

Table 18. Distribution of Households by Household Vehicle Availability and Population Density, 1990 and 1995 NPTS, and 2001 NHTS . . . . . . . . . . 34

Table 19. Percent of Households Without a Vehicle Within MSA Size Group, 1977, 1983, 1990 and 1995 NPTS, and 2001 NHTS . . . . . . . . . . . . 36

Table 20. Vehicle Distribution and Average Vehicle Age by Vehicle Type, 1977, 1983, 1990, and 1995 NPTS, and 2001 NHTS . . . . . . . . . . . . 37

Table 21. Distribution of Vehicles by Vehicle Age and Vehicle Type, 1969, 1977, 1983, 1990, and 1995 NPTS, and 2001 NHTS . . . . . . . . . . 38

Table 22. Average Annual Miles per Vehicle by Vehicle Age, 1969, 1977, 1983, 1990, and 1995 NPTS, and 2001 NHTS . . . . . . . . . 40

Table 23. Average Annual Miles per Licensed Driver by Driver Age and Gender, 1969, 1977, 1983, 1990, and 1995 NPTS, and 2001 NHTS . . . . . . . . . 41

\section{Commute Travel Patterns}

Table 24. Commute VMT and Total VMT By Year, 1969, 1977, 1983, 1990, and 1995 NPTS, and 2001 NHTS

Table 25. Distribution of Workers by Usual Mode, 1969, 1977, 1983, 1990, and 1995 NPTS, and 2001 NHTS .44

Table 26. General Commute Patterns by Mode of Transportation, 1983, 1990, and 1995 NPTS, and 2001 NHTS 
Table 27. Average Commute Speed by MSA Size, 1983, 1990, and 1995 NPTS, and 2001

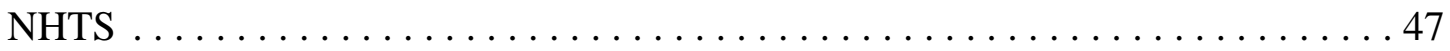

\section{Temporal Distribution}

Table 28. Distribution of Person Trips by Start Time of Trip, 1983, 1990, and 1995 NPTS, and 2001 NHTS . . . . . . . . . . . . . . . . . . . . 49

Table 29. Daily Travel Statistics by Weekday vs Weekend, Adjusted 1990

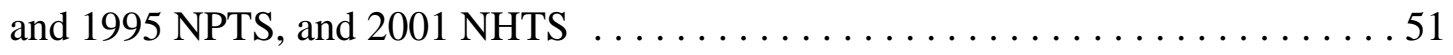

\section{Travel Behavior of Sub-Populations}

Table 30. Daily Travel Statistics of People 65 and Older, 1983, 1990, and 1995 NPTS, and 2001 NHTS . . . . . . . . . . . . . . . . . . . . . . . . . . . 52

Table 31. Daily Person Trips of Adult Women by Household Composition,

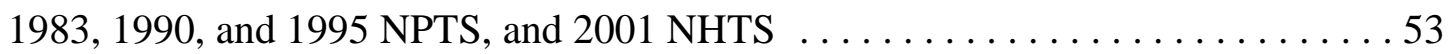

Table 32. Daily Person Trips per Person for Low Income Households by Trip Purpose,

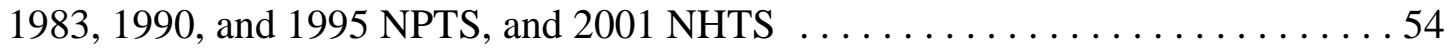

Table 33. Daily Person Trips per Person by Vehicle Ownership Status and MSA Size, Adjusted 1990 and 1995 NPTS, and 2001 NHTS 55 
This page intentionally left blank. 


\section{LIST OF FIGURES}

\section{Travel and Demographic Summary}

Figure 1. Changes in Summary Demographics, 1969, 1977, 1983, 1990, 1995 NPTS,

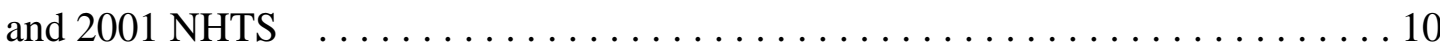

\section{Person Travel}

Figure 2. Distribution of Person Trips per Person by Gender and Trip Purpose, 1995 NPTS and 2001 NHTS . . . . . . . . . . . . . . . . . . . . . . . . . . . . 21

Figure 3. Average Daily Person Trips by Age and Gender From 1995 to 2001 . . . . . . . . 25

Figure 4. Average Daily Person Miles of Travel per Person by Gender, 1995 NPTS and 2001 NHTS . . . . . . . . . . . . . . . . . . . . . . . . . . . . . 27

Figure 5. Average Time Spent in Vehicle (Minutes) by Age, 2001 NHTS . . . . . . . . . . 28

Figure 6. Average Time Spent in Vehicle and Miles Traveled, 1995 NPTS and 2001 NHTS . 29

\section{Vehicle Availability and Utilization}

Figure 7. Household Distribution by Household Income and Vehicle to Driver Ratio, 2001 NHTS . . . . . . . . . . . . . . . . . . . . . . . . . 33

Figure 8. Vehicle Ownership and Demographic Statistics by Population Density, 2001 NHTS . . . . . . . . . . . . . . . . . . . . . . . . . . . . 35

Figure 9. Distribution of Vehicles by Vehicle Age 1977, 1983, 1990, 1995 NPTS, and 2001 NHTS 


\section{Commute Travel Patterns}

Figure 10. Distribution of Workers by Usual Mode, 1995 NPTS and 2001 NHTS . . . . . . 43

Figure 11. Average Commute Time in Privately-Owned Vehicles and MSA Size, 1995 NPTS and 2001 NHTS . . . . . . . . . . . . . . . . . . . . . . . . . . 46

Figure 12. Average Commute Speed for Selected Time of Day by MSA Size,

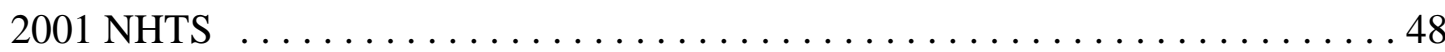

\section{Temporal Distribution}

Figure 13. Distribution of Person Trips by Trip Purpose and Start Time of Trip, 2001 NHTS 50

\section{Travel Behavior of Sub-Populations}

Figure 14. Mode Distribution of Person Trips Taken by Zero-Vehicle Households, 2001 NHTS . . . . . . . . . . . . . . . . . . . . . . . . . . . . 56 


\section{Summary of Travel Trends}

\section{National Household Travel Survey}


This page intentionally left blank. 


\section{Summary of Travel Trends 2001 National Household Travel Survey}

\section{INTRODUCTION}

Policymakers rely on transportation statistics, including data on personal travel behavior, to formulate strategic transportation policies and to improve the safety and efficiency of the U.S. transportation system. Data on personal travel trends are needed to examine the reliability, efficiency, capacity, safety, and flexibility of the nation's transportation system to meet current demands and accommodate future demands; to assess the feasibility and efficiency of alternative congestion alleviating technologies (e.g., high-speed rail, magnetically levitated trains, intelligent vehicle and highway systems); to evaluate the merits of alternative transportation investment programs; and to assess the energy-use and air-quality impacts of various policies.

To address these data needs, the U. S. Department of Transportation (USDOT) initiated an effort in 1969 to collect detailed data on personal travel. The 1969 survey was the first Nationwide Personal Transportation Survey (NPTS). The survey was conducted again in 1977, 1983, 1990, and 1995. In 2001, the survey was expanded by integrating the Federal Highway Administrationmanaged NPTS and the Bureau of Transportation Statistics-sponsored American Travel Survey (ATS). The survey was re-named to the National Household Travel Survey (NHTS).

The 2001 NHTS is the nation's inventory of daily and long-distance travel. The survey includes demographic characteristics of households, people, vehicles, and detailed information on daily and longer-distance travel for all purposes by all modes. NHTS survey data are collected from a sample of U.S. households and expanded to provide national estimates of trips and miles by travel mode, trip purpose, and a host of household attributes. When combined with historical data from 1969 through 1995, the 2001 NHTS survey data provide a rich source of detailed information on 
personal travel patterns over time.

\section{PROFILE OF THE 2001 NHTS}

Coverage. The NHTS collected travel data from a national sample of the civilian, noninstitutionalized population of the United States. Sampling was done by creating a random-digit dialing (RDD) list of telephone numbers. An eligible household excludes telephones in motels, hotels, group quarters, such as nursing homes, prisons, barracks, convents or monasteries and any living quarters with 10 or more unrelated roommates.

Telephones in dorm rooms, fraternity and sorority houses were eligible for sampling, provided that the residence had less than 11 household members sharing the same phone line. Therefore, students who normally reside at school but were living at home for the summer were not considered household members at their parent's home.

Household members included people who think of the sampled household as their primary place of residence. It included persons who usually stay in the household but were temporarily away on business, vacation, or in a hospital. It did not include people just visiting, such as a college student who normally lives away at school.

When The 2001 NHTS for the national and New York and Wisconsin add-ons was conducted over a period from March 2001 through May 2002. Data collection for the remaining add-on areas extended to July 2002.

Sample Size. The sample size for the 2001 NHTS was 69,817 households comprised of:

- a national sample of 26,038 completed households, and 
- 43,779 additional households collected for the use of and funded by nine addon areas:

\author{
Baltimore, MPO; \\ Des Moines, MPO; \\ Hawaii; \\ Kentucky (4 counties); \\ Lancaster PA, MPO; \\ New York State; \\ Oahu (Honolulu MPO); \\ Texas state; and \\ Wisconsin state.
}

Contents. The NHTS serves as the nation's inventory of daily personal travel. It includes, but is not limited to:

- household data on the relationship of household members, education level, income, housing characteristics, and other demographic information;

- information on each household vehicle, including year, make, model, and estimates of annual miles traveled and fuel costs;

- data about drivers, including information on travel as part of work;

- data about one-way trips taken during a designated 24-hour period (the household's designated travel day), including the time the trip began and ended, length of the trip, composition of the travel party, mode of transportation, purpose of the trip, and the specific vehicle used (if a household vehicle);

- data describing round-trips taken during a four-week period (the household's designated travel period) where the farthest point of the trip was at least 50 miles from home, including the farthest destination, access and egress stops and overnight stays on the way to and from the farthest destination, mode, purpose, and travel party information; 
- if no long-distance trips were made during the four-week travel period, data on the most recent long-distance trip by any mode and the most recent long-distance train trip;

- information to describe characteristics of the geographic area in which the sample household and workplace of sample persons are located;

- data on telecommuting;

- public perceptions of the transportation system;

- data on Internet usage; and

- the typical number of transit, walk and bike trips made over a period longer than the 24-hour travel day.

For more information on the 2001 survey methodology and procedures, please consult: "User's Guide for the Public Use Data Files 2001 National Household Travel Survey" available at:

\section{http://nhts.ornl.gov/2001/usersguide/index.shtml}

\section{IMPROVEMENTS IN THE NPTS/NHTS SERIES}

The US DOT continues to research and embrace improved methodologies to collect more accurate and more complete travel data, and to increase response rates. Among the changes in the 2001 NHTS, two are especially significant. First, the 2001 survey was the first survey in the NPTS/NHTS series that collects travel by household members younger than 5 years old. All previous surveys had collected travel only from household members age 5 and older. To facilitate compatible trend analysis, information about travel by individuals younger than 5 years old is excluded in the main body of the report. However, their travel was included in a few key tables that are presented in Appendix 1.

The second improvement in the 2001 NHTS survey was the improved, multiple prompting for walk and bike trips. This has significantly increased the number of walk and bike trips recorded. 
A complete comparison between the 1995 and 2001 survey methods is summarized in Appendix 2.

While improvements to the survey process are encouraged, changes in the 1995 survey method brought about significant data compatibility issues. To address these issues, the 1990 survey data were adjusted to allow comparison to the 1995 survey. In this report, both the original 1990 data and the adjusted 1990 data are reported to facilitate trends analysis. The reader is advised to compare the 1969-1983 survey results to the unadjusted 1990 data, and the 1995 and 2001 survey results to the adjusted 1990 data. The method used to adjust the 1990 travel data is described in Appendix 3.

\section{REPORT ORGANIZATION}

This report highlights important travel trends in tabular and graphic format. Statistics are categorized by topic. The report begins with a summary of travel and demographic changes. Next, travel changes are examined from an individual household perspective, then from an individual person perspective. This report concludes with trip-making statistics of sub-populations such as women, households without vehicles, low-income households, and the elderly. No attempt is made in this report to present all of the data or to analyze and discuss the data in any depth. Standard error estimates for key statistics are presented in Appendix 4. 


\section{Notes to Users of 2001 NHTS Data}

\section{Data Version}

Tables in this publication, the 2001 National Household Travel Survey (NHTS) Summary of Travel Trends, were prepared using the January 2004 release of the NHTS data. This version of the data includes data from all of the nine add-on areas.

\section{Travel of 0-4 year-olds}

In 2001, the travel of 0 to 4 year-olds was measured for the first time. In order to make the 2001 data comparable to that of the previous surveys, the 2001 data reported in all tables exclude travel of this group of individuals unless explicitly stated otherwise (for example, Tables 1 and 3). Note that inclusion of travel taken by individuals 0 to 4 year-olds does not affect the statistics on vehicle trips, or vehicle miles of travel (VMT) because such measures are derived based on travel taken by the driver of the trip.

\section{To- and From-Work Trips}

The number of trips taken to, or from, work dropped substantially from 1995 to 2001 . Given the historical trends between 1990 and 2001, this decrease in the number of work trips could be attributable to the overestimated work travel in the 1995 survey data.

\begin{tabular}{||ccccc||}
\hline \hline Data Source & $\begin{array}{c}\text { Work Trips } \\
(000,000 \mathrm{~s})\end{array}$ & $\begin{array}{c}\text { Workers } \\
(000 \mathrm{~s})\end{array}$ & $\begin{array}{c}\text { Work Trips } \\
\text { per Worker }\end{array}$ & $\begin{array}{c}\text { Daily Work Trips } \\
\text { per Worker }\end{array}$ \\
\hline 1990 NPTS & 50,314 & 118,343 & 425 & 1.16 \\
1995 NPTS & 66,901 & 131,697 & 508 & 1.39 \\
2001 NHTS & 60,690 & 145,272 & 418 & 1.14 \\
\hline
\end{tabular}

\section{Walk Trips}

Respondents to the 2001 NHTS were specifically prompted to report walk trips. Since this was not done in the previous surveys, the increases in the number of walk trips can be explained, at least in part, by this change in methodology. 


\section{Notes to Users (Continued)}

\section{Nonresponse Weighting}

In the 2001 NHTS, special care was given to nonresponse adjustments in the weighting of the survey data. This was done to make the weighted survey results more representative of the U.S. population. For example, these adjustments increase the weighted survey results of low-income households, thereby help compensate for the low response rate of these households. The improved weighting for nonresponse may account for part of the reduction, from 1995 to 2001, in the average number of trips taken by a low-income household. 
This page intentionally left blank. 
Table 1

Summary Statistics on Demographic Characteristics and Total Travel 1969, 1977, 1983, 1990, and 1995 NPTS, and 2001 NHTS

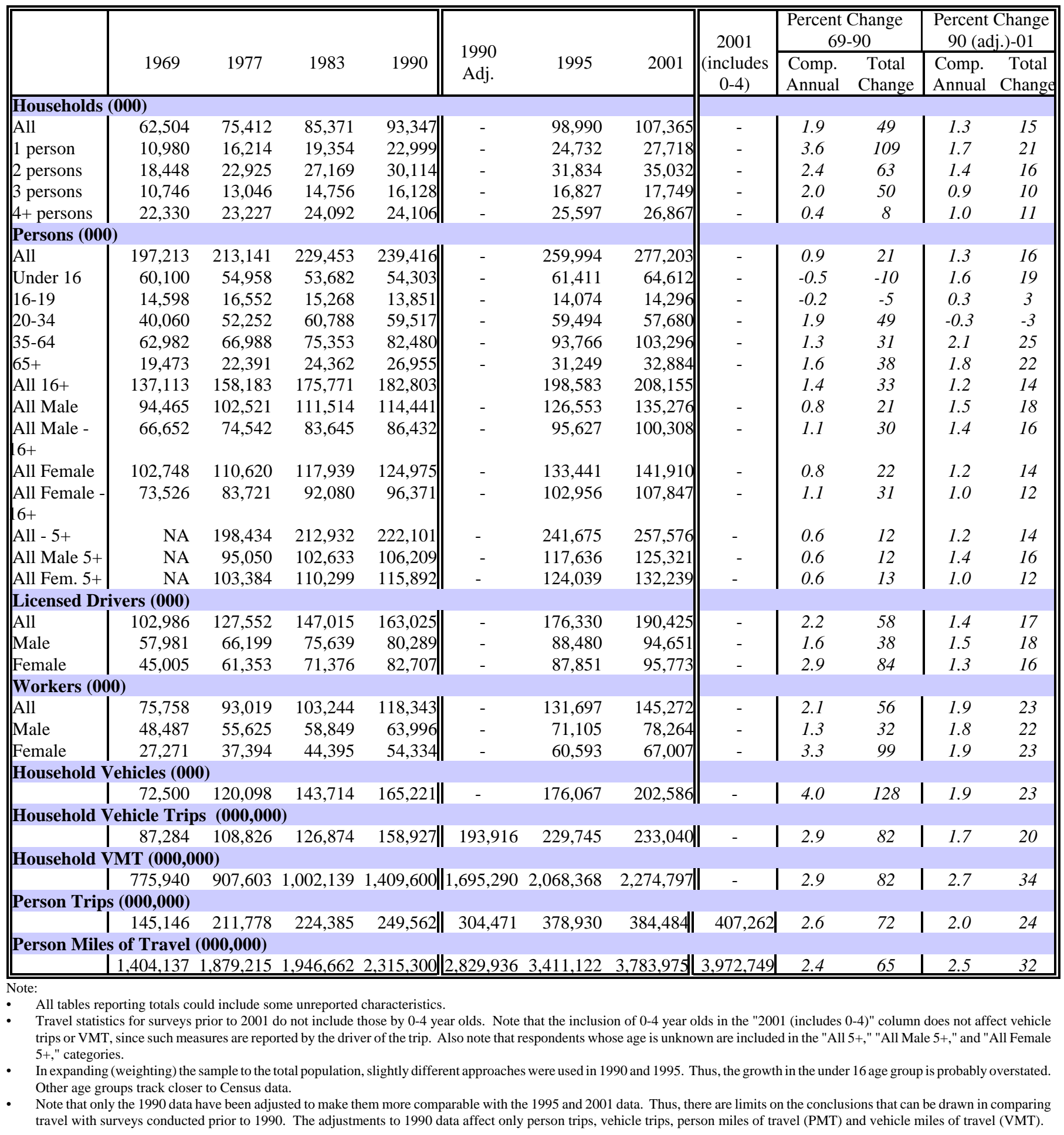


During the past three decades, the number of vehicles increased at a steeper rate than most other demographic indicators. For example, it increased at an annual rate that was almost one and one-half times that of the total number of licensed drivers.

Figure 1

Changes in Summary Demographics

$1969^{1}, 1977,1983,1990,1995$ NPTS, and 2001 NHTS

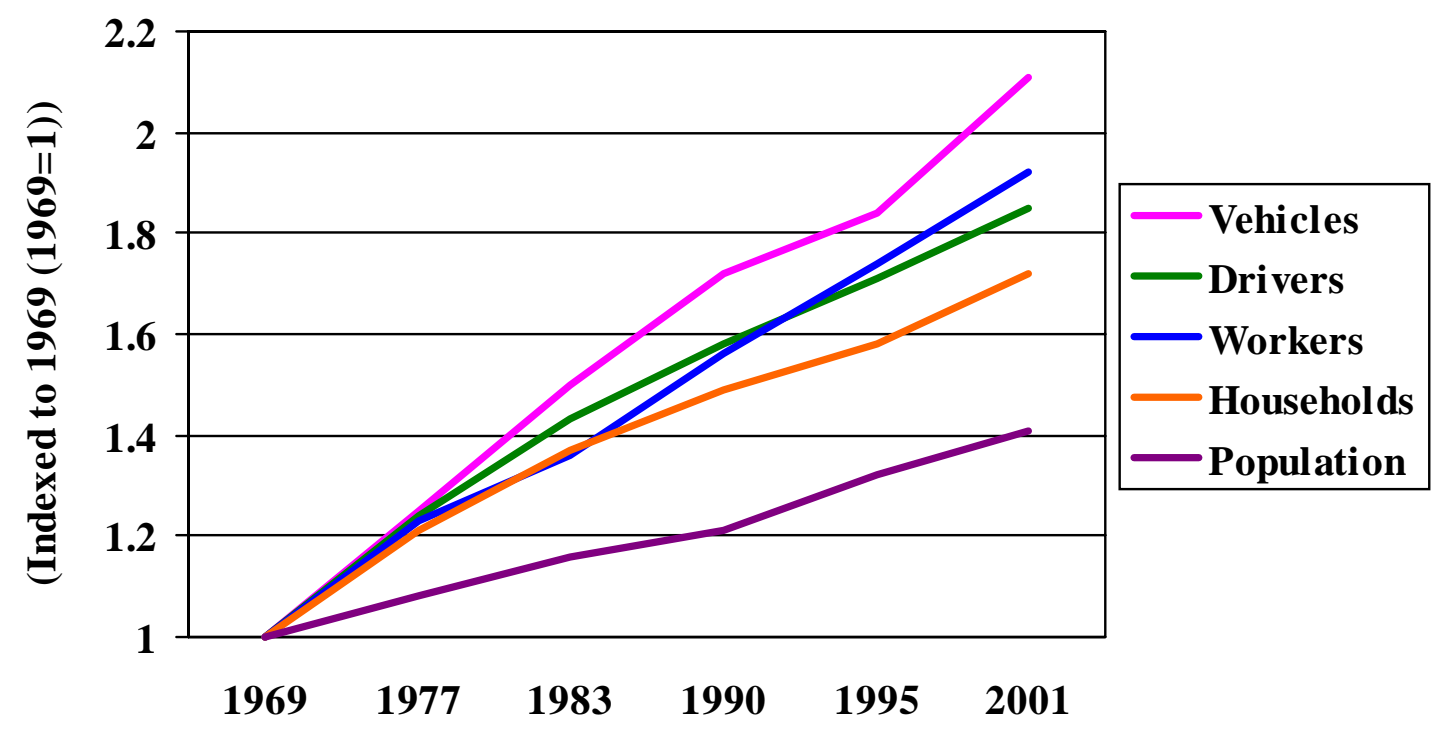

1 The 1969 NPTS survey did not include trucks as household vehicles. For comparability across surveys, the number of household vehicles in 1969 was estimated based on statistics reported in Highway Statistics. It was assumed that fifty percent of all 2-axle 4-tire vehicles in 1969 were used for personal purposes, resulting in a total estimate 95,876,000 household vehicles $[=89,173,502+50 \% \times 13,405,772]$. 
The typical American household continues to own more vehicles. The percentage of households who own 3 or more vehicles increased from 19\% in 1995 to 23\% in 2001 (Table 17). The number of workers per household increased slightly, probably reflecting the trend in which retirees return to the labor market.

Table 2

Summary of Demographic Trends

1969, 1977, 1983, 1990, 1995 NPTS, and 2001 NHTS

\begin{tabular}{||l|cccccc||}
\hline & $\mathbf{1 9 6 9}$ & $\mathbf{1 9 7 7}$ & $\mathbf{1 9 8 3}$ & $\mathbf{1 9 9 0}$ & $\mathbf{1 9 9 5}$ & $\mathbf{2 0 0 1}$ \\
Persons per household & 3.16 & 2.83 & 2.69 & 2.56 & 2.63 & 2.58 \\
Vehicles per household & 1.16 & 1.59 & 1.68 & 1.77 & 1.78 & 1.89 \\
Licensed drivers per household & 1.65 & 1.69 & 1.72 & 1.75 & 1.78 & 1.77 \\
Vehicles per licensed driver & 0.70 & 0.94 & 0.98 & 1.01 & 1.00 & 1.06 \\
Workers per household & 1.21 & 1.23 & 1.21 & 1.27 & 1.33 & 1.35 \\
Vehicles per worker & 0.96 & 1.29 & 1.39 & 1.40 & 1.34 & 1.39 \\
\hline
\end{tabular}

Note:

- The 1969 survey does not include pickups and other light trucks as household vehicles. 
Despite the improvement in the 2001 survey where particular attention was given to accurately record walking trips, Americans took fewer trips in 2001 than in 1995. However, this by no means suggests that Americans became less mobile. Although fewer trips were taken, the trips were longer in 2001 than in previous years.

Table 3

Summary of Travel Statistics

1969, 1977, 1983, 1990, 1995 NPTS, and 2001 NHTS

\begin{tabular}{|c|c|c|c|c|c|c|c|c|}
\hline & 1969 & 1977 & 1983 & 1990 & $\begin{array}{l}1990 \\
\text { Adj. }\end{array}$ & 1995 & 2001 & \begin{tabular}{l}
\multicolumn{1}{c}{2001} \\
(includes trips by \\
children younger \\
than 4 year olds)
\end{tabular} \\
\hline \multicolumn{9}{|l|}{ Per Person } \\
\hline Daily Person Trips & 2.02 & 2.92 & 2.89 & 3.08 & 3.76 & 4.30 & 3.74 & 4.03 \\
\hline Daily PMT & 19.51 & 25.95 & 25.05 & 28.56 & 34.91 & 38.67 & 36.89 & 39.26 \\
\hline \multicolumn{9}{|l|}{ Per Driver } \\
\hline Daily Vehicle Trips & 2.32 & 2.34 & 2.36 & 2.67 & 3.26 & 3.57 & 3.35 & - \\
\hline Daily VMT & 20.64 & 19.49 & 18.68 & 23.69 & 28.49 & 32.14 & 32.73 & - \\
\hline \multicolumn{9}{|l|}{ Per Household } \\
\hline Daily Person Trips & 6.36 & 7.69 & 7.20 & 7.32 & 8.94 & 10.49 & 9.66 & 10.39 \\
\hline Daily PMT & 61.55 & 68.27 & 62.47 & 67.95 & 83.06 & 94.41 & 95.24 & 101.38 \\
\hline Daily Vehicle Trips & 3.83 & 3.95 & 4.07 & 4.66 & 5.69 & 6.36 & 5.95 & - \\
\hline Daily VMT & 34.01 & 32.97 & 32.16 & 41.37 & 49.76 & 57.25 & 58.05 & - \\
\hline \multicolumn{9}{|l|}{ Per Trip } \\
\hline $\begin{array}{l}\text { Average person trip } \\
\text { length (miles) } \\
\text { Average vehicle trip }\end{array}$ & 9.67 & 8.87 & 8.68 & 9.45 & 9.47 & 9.13 & 10.04 & 9.94 \\
\hline length (miles) & 8.89 & 8.34 & 7.90 & 8.98 & 8.85 & 9.06 & 9.87 & - \\
\hline
\end{tabular}

Note:

- Average vehicle trip length for 1990, 1995, and 2001 is calculated using only those records with trip mileage information present.

- Note that inclusion of the 0-4 year olds in travel measures does not change vehicle trips or VMT, since such measures are taken from the driver of the trip.

- The 1969 survey does not include pickups and other light trucks as household vehicles.

- Note that only the 1990 data have been adjusted to make them more comparable with the 1995 and 2001 data. Thus, there are limits on the conclusions that can be drawn in comparing travel with earlier survey years. The adjustments to 1990 data affect only person trips, vehicle trips, person miles of travel (PMT) and vehicle miles of travel (VMT). 
Table 4 compares data from the NPTS and NHTS, and those from other data sources. Given its project-specific goals, each data source has its own scope in terms of data collection method, target population, and data validation and estimation procedures. Therefore, comparison of NPTS/NHTS data to data from other sources is at best informative but not conclusive.

Data on the total number of households for year 2001 were estimated by the Bureau of Census of the U.S. Department of Commerce as reported in the Current Population Survey Report (March 2001 edition, from Census Bureau Web page, http://www.census.gov). Data on 2001 population were obtained from the Census Bureau Web page, http://www.census.gov. The NPTS estimated household population; the Bureau of Census measured resident and civilian population. The Bureau of Census' estimates are for July 1 of each year.

Data on the number of licensed drivers are reported by the Federal Highway Administration (FHWA) of the U.S. Department of Transportation (US DOT) in its annual Highway Statistics (Table DL-22 of the 2001 report). Note that Highway Statistics shows the cumulative number of driver's licenses issued, while the NPTS estimates the number of people who hold a driver's license. (The Highway Statistics series can be found at: www.fhwa.dot.gov/ohim/ohimstat.htm.)

The NPTS's and NHTS's estimate on vehicles includes all household-based vehicles but excludes most fleet vehicles, whereas Highway Statistics reports all vehicles (personal and commercial) categorized by vehicle type (e.g., automobiles, 2-axle, 4-tire trucks, etc.). To estimate comparable "household-based" vehicles from Highway Statistics, all of the automobiles, motorcycles, and a percentage of the 2-axle 4-tire trucks are assumed to be household-based vehicles. The percent 2-axle 4-tire trucks used for personal purposes is estimated from the Truck Inventory and Use Surveys (TIUS) and varies by year:

1977: $63.21 \%$ trucks, from 1977 TIUS

1983: 64.20\% trucks, from 1982 TIUS

1990: $72.38 \%$ trucks, from 1990 TIUS

1995: 73.90\% trucks, from 1992 TIUS

2001: 74.85\% trucks, from 1997 TIUS 
Table 4

Comparison of Survey Variables with Other Sources (thousands)

\begin{tabular}{|c|c|c|c|c|}
\hline & Households & Population & $\begin{array}{c}\text { Licensed } \\
\text { Drivers }\end{array}$ & Vehicles \\
\hline \multicolumn{5}{|c|}{1969} \\
\hline Other Sources & 61,806 & 199,145 & 108,306 & 89,174 \\
\hline NPTS & 62,504 & 197,213 & 102,986 & 72,500 \\
\hline \multicolumn{5}{|c|}{1977} \\
\hline Other Sources & 74,142 & 218,106 & 138,121 & 132,155 \\
\hline NPTS & 75,412 & 213,141 & 127,552 & 120,098 \\
\hline \multicolumn{5}{|c|}{1983} \\
\hline Other Sources & 83,918 & 232,086 & 154,389 & 152,070 \\
\hline NPTS & 85,371 & 229,453 & 147,015 & 143,714 \\
\hline \multicolumn{5}{|c|}{1990} \\
\hline Other Sources & 91,947 & 247,826 & 167,015 & 172,902 \\
\hline NPTS & 93,347 & 239,416 & 163,025 & 165,221 \\
\hline \multicolumn{5}{|c|}{1995} \\
\hline Other Sources & 97,386 & 261,538 & 176,628 & 180,735 \\
\hline NPTS & 98,990 & 259,994 & 176,330 & 176,067 \\
\hline \multicolumn{5}{|c|}{2001} \\
\hline Other Sources & 108,209 & 285,318 & 191,276 & 205,551 \\
\hline NHTS & 107,365 & 277,203 & 190,425 & 202,586 \\
\hline
\end{tabular}

Note:

- See the previous page for details on sources for other years.

- The 1969 NPTS survey includes only automobiles, station wagons, and van buses/minibuses as household vehicles. 
Compared to 1995, a typical household traveled slightly more miles in 2001. This increase took the form of fewer, but generally longer trips. The average distance for commuting to work continued to increase.

Table 5

Average Annual PMT, Person Trips and Trip Length by Trip Purpose 1983, 1990, 1995 NPTS, and 2001 NHTS

\begin{tabular}{|c|c|c|c|c|c|}
\hline Trip Purpose & 1983 & 1990 & 1990 Adjusted & 1995 & 2001 \\
\hline \multicolumn{6}{|c|}{ Average Annual PMT per Household } \\
\hline All Purposes & 22,802 & 24,803 & 30,316 & 34,459 & 35,244 \\
\hline To/From Work & 4,586 & 5,637 & 5,637 & 7,740 & 6,706 \\
\hline Work Related Business & 1,354 & 1,043 & 1,043 & 1,987 & 2,987 \\
\hline Shopping & 2,567 & 2,674 & 3,343 & 4,659 & 4,887 \\
\hline All Other Fam/Per Business & 3,311 & 5,083 & 7,167 & 7,381 & 6,671 \\
\hline School/Church & 1,522 & 1,599 & 1,599 & 1,973 & 2,060 \\
\hline Social and Recreational & 8,964 & 8,567 & 11,308 & 10,571 & 10,586 \\
\hline Other & 500 & 195 & 214 & 131 & 1,216 \\
\hline \multicolumn{6}{|c|}{ Average Annual Person Trips per Household } \\
\hline All Purposes & 2,628 & 2,673 & 3,262 & 3,828 & 3,581 \\
\hline To/From Work & 537 & 539 & 539 & 676 & 565 \\
\hline Work Related Business & 62 & 38 & 38 & 100 & 109 \\
\hline Shopping & 474 & 504 & 630 & 775 & 707 \\
\hline All Other Fam/Per Business & 456 & 606 & 854 & 981 & 863 \\
\hline School/Church & 310 & 304 & 304 & 337 & 351 \\
\hline Social and Recreational & 728 & 662 & 874 & 953 & 952 \\
\hline Other & 61 & 20 & 22 & 6 & 30 \\
\hline \multicolumn{6}{|c|}{ Average Person Trip Length (miles) } \\
\hline All Purposes & 8.68 & 9.45 & 9.47 & 9.13 & 10.03 \\
\hline To/From Work & 8.54 & 10.65 & 10.65 & 11.63 & 12.11 \\
\hline Work Related Business & 21.77 & 28.20 & 28.20 & 20.28 & 28.26 \\
\hline Shopping & 5.41 & 5.38 & 5.38 & 6.08 & 7.02 \\
\hline All Other Fam/Per Business & 7.27 & 8.55 & 8.55 & 7.63 & 7.84 \\
\hline School/Church & 4.90 & 5.39 & 5.39 & 5.98 & 6.00 \\
\hline Social and Recreational & 12.31 & 13.19 & 13.19 & 11.27 & 11.36 \\
\hline Other & 8.22 & 10.30 & 10.30 & 22.83 & 43.08 \\
\hline
\end{tabular}

Note:

- 1995 VMT and vehicle trips with "To or From Work" as a trip purpose are believed to be overstated.

- Average person trip length for 1990, 1995, and 2001 is calculated using only those records with trip mileage information present.

- All tables reporting totals could include some unreported characteristics.

- Note that only the 1990 data have been adjusted to make them more comparable with the 1995 and 2001 data. Thus, there are limits on the conclusions that can be drawn in comparing travel with earlier survey years. The adjustments to 1990 data affect only person trips, vehicle trips, person miles of travel (PMT) and vehicle miles of travel (VMT).

- See Appendix for 2001 figures including 0 to 4 year-olds. 
Similar to what was observed in the 1995 survey, commuting had the largest share of vehicle travel. In the past, social and recreational trips had the longest average driving distance among all trips. However, this pattern has changed since 1995, with commuting trips becoming the longest.

Table 6

Average Annual VMT, Vehicle Trips and Trip Length by Selected Trip Purposes 1969, 1977, 1983, 1990, 1995 NPTS, and 2001 NHTS

\begin{tabular}{|c|c|c|c|c|c|c|c|}
\hline Trip Purpose & 1969 & 1977 & 1983 & 1990 & $\begin{array}{c}1990 \\
\text { Adjusted }\end{array}$ & 1995 & 2001 \\
\hline \multicolumn{8}{|c|}{ Average Annual VMT per Household } \\
\hline All Purposes & 12,423 & 12,036 & 11,739 & 15,100 & 18,161 & 20,895 & 21,187 \\
\hline To or From Work & 4,183 & 3,815 & 3,538 & 4,853 & 4,853 & 6,492 & 5,724 \\
\hline Shopping & 929 & 1,336 & 1,567 & 1,743 & 2,178 & 2,807 & 3,062 \\
\hline Other Fam \& Personal Business & 1,270 & 1,444 & 1,816 & 3,014 & 4,250 & 4,307 & 3,956 \\
\hline Social and Recreational & 4,094 & 3,286 & 3,534 & 4,060 & 5,359 & 4,764 & 5,186 \\
\hline \multicolumn{8}{|c|}{ Average Annual Vehicle Trips per Household } \\
\hline All Purposes & 1,396 & 1,442 & 1,486 & 1,702 & 2,077 & 2,321 & 2,171 \\
\hline To or From Work & 445 & 423 & 414 & 448 & 448 & 553 & 479 \\
\hline Shopping & 213 & 268 & 297 & 345 & 431 & 501 & 459 \\
\hline Other Fam. \& Personal Business & 195 & 215 & 272 & 411 & 579 & 626 & 537 \\
\hline Social and Recreational & 312 & 320 & 335 & 349 & 460 & 427 & 441 \\
\hline \multicolumn{8}{|c|}{ Average Vehicle Trip Length (miles) } \\
\hline All Purposes & 8.90 & 8.35 & 7.90 & 8.98 & 8.85 & 9.06 & 9.87 \\
\hline To or From Work & 9.40 & 9.02 & 8.55 & 10.97 & 10.97 & 11.80 & 12.08 \\
\hline Shopping & 4.36 & 4.99 & 5.28 & 5.10 & 5.10 & 5.64 & 6.74 \\
\hline Other Fam. \& Personal Business & 6.51 & 6.72 & 6.68 & 7.43 & 7.43 & 6.93 & 7.45 \\
\hline Social and Recreational & 13.12 & 10.27 & 10.55 & 11.80 & 11.80 & 11.24 & 11.91 \\
\hline
\end{tabular}

Note:

- 1995 VMT and vehicle trips with "To or From Work" as a trip purpose are believed to be overstated.

- Average vehicle trip length for 1990, 1995, and 2001 is calculated using only those records with trip mileage information present.

- All purposes includes other purposes not shown above, such as trips to school, church, doctor, dentist, and work-related business trips.

- All tables reporting totals could include some unreported characteristics.

- Note that only the 1990 data have been adjusted to make them more comparable with the 1995 and 2001 data. Thus, there are limits on the conclusions that can be drawn in comparing travel with earlier survey years. The adjustments to 1990 data affect only person trips, vehicle trips, person miles of travel (PMT) and vehicle miles of travel (VMT). 
Table 7

Average Annual Person Trips per Household

by Mode of Transportation and MSA Size

1977, 1983, 1990, 1995 NPTS, and 2001 NHTS

\begin{tabular}{|c|c|c|c|c|c|c|}
\hline \multicolumn{7}{|c|}{ Mode of Transportation } \\
\hline SMSA or MSA Size & 1977 & 1983 & 1990 & 1990 Adjusted & 1995 & 2001 \\
\hline \multicolumn{7}{|c|}{ Private } \\
\hline ALL & 2,351 & 2,152 & 2,329 & 2,861 & 3,307 & 3,090 \\
\hline Not in $(\mathrm{S}) \mathrm{MSA}$ & 2,436 & 2,322 & 2,306 & 2,837 & 3,492 & 3,076 \\
\hline Less than 250,000 & 2,517 & 2,375 & 2,508 & 3,090 & 3,503 & 3,304 \\
\hline $250,000-499,999$ & 2,574 & 2,443 & 2,461 & 3,014 & 3,472 & 3,251 \\
\hline $500,000-999,999$ & 2,628 & 2,140 & 2,413 & 2,957 & 3,509 & 3,348 \\
\hline $1,000,000$ - 2,999,999 & 2,366 & 2,031 & 2,430 & 2,986 & 3,354 & 3,174 \\
\hline $3,000,000$ and above & 1,785 & 1,691 & 2,160 & 2,649 & 3,075 & 2,911 \\
\hline \multicolumn{7}{|c|}{ PublicTransit } \\
\hline ALL & 73 & 60 & 52 & 58 & 67 & 58 \\
\hline Not in (S)MSA & 22 & 11 & 13 & 14 & 9 & 6 \\
\hline Less than 250,000 & 47 & 17 & 27 & 30 & 23 & 12 \\
\hline $250,000-499,999$ & 44 & 23 & 19 & 22 & 18 & 18 \\
\hline $500,000-999,999$ & 58 & 48 & 28 & 33 & 33 & 11 \\
\hline $1,000,000$ - 2,999,999 & 86 & 67 & 46 & 52 & 37 & 36 \\
\hline $3,000,000$ and above & 189 & 181 & 112 & 124 & 137 & 128 \\
\hline \multicolumn{7}{|c|}{ Walk } \\
\hline ALL & 261 & 226 & 193 & 234 & 205 & 309 \\
\hline Not in (S)MSA & 199 & 211 & 146 & 175 & 134 & 221 \\
\hline Less than 250,000 & 241 & 280 & 172 & 212 & 138 & 248 \\
\hline $250,000-499,999$ & 206 & 199 & 165 & 203 & 152 & 251 \\
\hline 500,000 - 999,999 & 256 & 184 & 132 & 161 & 138 & 224 \\
\hline $1,000,000-2,999,999$ & 295 & 179 & 170 & 207 & 162 & 275 \\
\hline $3,000,000$ and above & 396 & 330 & 278 & 337 & 301 & 423 \\
\hline \multicolumn{7}{|c|}{ ALL MODES } \\
\hline ALL & 2,808 & 2,628 & 2,673 & 3,262 & 3,828 & 3,581 \\
\hline Not in (S)MSA & 2,800 & 2,766 & 2,580 & 3,151 & 3,878 & 3,435 \\
\hline Less than 250,000 & 2,944 & 2,889 & 2,816 & 3,450 & 3,926 & 3,678 \\
\hline $250,000-499,999$ & 2,945 & 2,891 & 2,741 & 3,340 & 3,894 & 3,645 \\
\hline 500,000 - 999,999 & 3,049 & 2,542 & 2,667 & 3,252 & 3,916 & 3,692 \\
\hline $1,000,000$ - 2,999,999 & 2,861 & 2,463 & 2,737 & 3,344 & 3,795 & 3,602 \\
\hline $3,000,000$ and above & 2,459 & 2,326 & 2,641 & 3,213 & 3,765 & 3,593 \\
\hline
\end{tabular}

Note:

- Increases in Walk trips in 2001 are due, at least in part, to respondents being explicitly asked to include walk trips, which was not the case in prior surveys.

- The population size groups for 1977 - 1983 NPTS are SMSA Size Groups and 1990 - 2001 are MSA Size Groups.

- In 2001, the mode "Bus" was divided into "Local Public Transit Bus," "Commuter Bus," "Charter/tour bus," and "City to city bus.” Only "Local Public Transit Bus" and "Commuter Bus" are included in public transit calculations.

- $\quad$ All modes includes other modes not specified such as bike, school bus, taxi and other.

- All tables reporting totals could include some unreported characteristics. Of particular interest, trips with an unreported mode dropped from 126 per household in 1995 to 2 in 2001.

- Note that only the 1990 data have been adjusted to make them more comparable with the 1995 and 2001 data. Thus, there are limits on the conclusions that can be drawn in comparing travel with earlier survey years. The adjustments to 1990 data affect only person trips, vehicle trips, person miles of travel (PMT) and vehicle miles of travel (VMT).

- See Appendix for 2001 figures including 0 to 4 year-olds. 
Since the NHTS sample excluded households without telephones, care should be taken in interpreting results that might be affected by telephone ownership (which is related to family income). For example, estimates of survey data categorized by family income could underestimate trips made by low-income households and, therefore, not adequately represent the population as a whole. Travel by more affluent households continued to grow, widening the gap between low-income and high-income households.

\section{Table 8}

Person Trips per Household by Household Income 1983, 1990, and 1995 NPTS and 2001 NHTS

\begin{tabular}{||l|cc||ccc|c||}
\hline Income & 1983 & 1990 & $\begin{array}{c}1990 \\
\text { Adjusted }\end{array}$ & 1995 & 2001 & $\begin{array}{c}\text { Annual } \\
\text { Compounded } \\
\text { Rate, } \\
1990-2001\end{array}$ \\
ALL & 2,628 & 2,673 & 3,262 & 3,828 & 3,581 & $0.9 \%$ \\
$<\$ 10,000$ & 1,407 & 1,710 & 2,098 & 2,137 & 2,046 & $-0.2 \%$ \\
$\$ 10$ to $\$ 20,000$ & 1,927 & 1,968 & 2,412 & 2,790 & 2,542 & $0.5 \%$ \\
$\$ 20$ to $\$ 30,000$ & 2,376 & 2,455 & 3,008 & 3,522 & 3,065 & $0.2 \%$ \\
$\$ 30$ to $\$ 40,000$ & 2,739 & 2,802 & 3,431 & 3,980 & 3,535 & $0.3 \%$ \\
$\$ 40$ to $\$ 50,000$ & 3,037 & 3,101 & 3,791 & 4,298 & 3,905 & $0.3 \%$ \\
$\$ 50$ to $\$ 60,000$ & 3,284 & 3,391 & 4,138 & 4,539 & 4,348 & $0.5 \%$ \\
$\$ 60$ to $\$ 70,000$ & 3,485 & 3,660 & 4,458 & 4,726 & 4,545 & $0.2 \%$ \\
$\$ 70$ to $\$ 80,000$ & 3,635 & 3,832 & 4,659 & 4,855 & 4,867 & $0.4 \%$ \\
$\$ 80,000+$ & 3,602 & 3,747 & 4,570 & 4,829 & 4,934 & $0.7 \%$ \\
Unreported & & 2,090 & 2,536 & 3,424 & 2,431 & $-0.4 \%$ \\
\hline \hline
\end{tabular}

Note:

- Incomes for 1983, 1990, adjusted 1990, and 1995 have been adjusted to 2001 dollars.

- All tables reporting totals could include some unreported characteristics.

- Note that only the 1990 person trip data have been adjusted to make them more comparable with the 1995 and 2001 data. Thus, there are limits on the conclusions that can be drawn in comparing travel with earlier survey years. The adjustments to 1990 data affect only person trips, vehicle trips, person miles of travel (PMT) and vehicle miles of travel (VMT).

- See Appendix for 2001 figures including 0 to 4 year-olds. 


\section{Table 9}

Total Person Trips by Mode of Transportation and Trip Purpose Adjusted 1990 and 1995 NPTS, and 2001 NHTS (millions)

\begin{tabular}{|c|c|c|c|c|c|c|c|}
\hline & Total & $\begin{array}{l}\text { To/ From } \\
\text { Work }\end{array}$ & $\begin{array}{c}\text { Work- } \\
\text { Related } \\
\text { Business }\end{array}$ & $\begin{array}{l}\text { Family/ } \\
\text { Personal } \\
\text { Business }\end{array}$ & $\begin{array}{l}\text { School or } \\
\text { Church }\end{array}$ & $\begin{array}{c}\text { Social and } \\
\text { Recreational }\end{array}$ & Other \\
\hline \multicolumn{8}{|c|}{ Private } \\
\hline 1990 Adj & $\begin{array}{l}267,029 \\
(87.8 \%)\end{array}$ & $\begin{array}{c}45,856 \\
(91.2 \%)\end{array}$ & $\begin{array}{c}3,178 \\
(90.3 \%)\end{array}$ & $\begin{array}{l}128,368 \\
(92.7 \%)\end{array}$ & $\begin{array}{c}17,545 \\
(61.9 \%)\end{array}$ & $\begin{array}{c}70,382 \\
(86.3 \%)\end{array}$ & $\begin{array}{c}1,629 \\
(81.4 \%)\end{array}$ \\
\hline 1995 & $\begin{array}{l}327,400 \\
(89.3 \%)\end{array}$ & $\begin{array}{c}60,740 \\
(92.8 \%)\end{array}$ & $\begin{array}{c}8,835 \\
(91.9 \%)\end{array}$ & $\begin{array}{l}156,065 \\
(92.6 \%)\end{array}$ & $\begin{array}{c}22,436 \\
(69.6 \%)\end{array}$ & $\begin{array}{c}78,809 \\
(87.6 \%)\end{array}$ & $\begin{array}{c}470 \\
(83.2 \%)\end{array}$ \\
\hline 2001 & $\begin{array}{l}331,791 \\
(86.3 \%)\end{array}$ & $\begin{array}{c}56,054 \\
(92.4 \%)\end{array}$ & $\begin{array}{c}10,648 \\
(91.2 \%)\end{array}$ & $\begin{array}{l}153,270 \\
(90.9 \%)\end{array}$ & $\begin{array}{c}26,861 \\
(71.3 \%)\end{array}$ & $\begin{array}{c}82,437 \\
(80.7 \%)\end{array}$ & $\begin{array}{c}2,147 \\
(67.2 \%)\end{array}$ \\
\hline \multicolumn{8}{|c|}{ Public Transit } \\
\hline 1990 Adj & $\begin{array}{c}5,460 \\
(1.8 \%)\end{array}$ & $\begin{array}{c}1,992 \\
(4.0 \%)\end{array}$ & $\begin{array}{c}92 \\
(2.6 \%)\end{array}$ & $\begin{array}{c}1,318 \\
(1.0 \%)\end{array}$ & $\begin{array}{c}1,076 \\
(3.8 \%)\end{array}$ & $\begin{array}{c}946 \\
(1.2 \%)\end{array}$ & $\begin{array}{c}35 \\
(1.7 \%)\end{array}$ \\
\hline 1995 & $\begin{array}{c}6,638 \\
(1.8 \%)\end{array}$ & $\begin{array}{l}2,328 \\
(3.6 \%)\end{array}$ & $\begin{array}{c}123 \\
(1.3 \%)\end{array}$ & $\begin{array}{l}2,000 \\
(1.2 \%)\end{array}$ & $\begin{array}{c}826 \\
(2.6 \%)\end{array}$ & $\begin{array}{l}1,350 \\
(1.5 \%)\end{array}$ & $\begin{array}{c}11 \\
(1.9 \%)\end{array}$ \\
\hline 2001 & $\begin{array}{c}6,202 \\
(1.6 \%)\end{array}$ & $\begin{array}{l}2,271 \\
(3.7 \%)\end{array}$ & $\begin{array}{c}213 \\
(1.8 \%)\end{array}$ & $\begin{array}{l}1,776 \\
(1.1 \%)\end{array}$ & $\begin{array}{c}800 \\
(2.1 \%)\end{array}$ & $\begin{array}{c}989 \\
(1.0 \%)\end{array}$ & $\begin{array}{c}134 \\
(4.2 \%)\end{array}$ \\
\hline \multicolumn{8}{|c|}{ Walk } \\
\hline 1990 Adj & $\begin{array}{l}21,879 \\
(7.2 \%)\end{array}$ & $\begin{array}{c}1,999 \\
(4.0 \%)\end{array}$ & $\begin{array}{c}154 \\
(4.4 \%)\end{array}$ & $\begin{array}{c}7,722 \\
(5.6 \%)\end{array}$ & $\begin{array}{c}3,649 \\
(12.8 \%)\end{array}$ & $\begin{array}{c}8,090 \\
(9.9 \%)\end{array}$ & $\begin{array}{c}265 \\
(13.2 \%)\end{array}$ \\
\hline 1995 & $\begin{array}{l}20,325 \\
(5.4 \%)\end{array}$ & $\begin{array}{l}1,510 \\
(2.3 \%)\end{array}$ & $\begin{array}{c}240 \\
(2.4 \%)\end{array}$ & $\begin{array}{c}8,756 \\
(5.0 \%)\end{array}$ & $\begin{array}{l}2,925 \\
(8.8 \%)\end{array}$ & $\begin{array}{l}6,845 \\
(7.3 \%)\end{array}$ & $\begin{array}{c}47 \\
(7.6 \%)\end{array}$ \\
\hline 2001 & $\begin{array}{l}33,145 \\
(8.6 \%)\end{array}$ & $\begin{array}{l}1,715 \\
(2.8 \%)\end{array}$ & $\begin{array}{c}487 \\
(4.2 \%)\end{array}$ & $\begin{array}{l}11,936 \\
(7.1 \%)\end{array}$ & $\begin{array}{l}3,630 \\
(9.6 \%)\end{array}$ & $\begin{array}{c}14,824 \\
(14.5 \%)\end{array}$ & $\begin{array}{c}507 \\
(15.9 \%)\end{array}$ \\
\hline \multicolumn{8}{|c|}{ Other } \\
\hline 1990 Adj & $\begin{array}{c}9,867 \\
(3.2 \%)\end{array}$ & $\begin{array}{c}428 \\
(0.8 \%)\end{array}$ & $\begin{array}{c}95 \\
(2.7 \%)\end{array}$ & $\begin{array}{l}1,087 \\
(0.8 \%)\end{array}$ & $\begin{array}{c}6,086 \\
(21.4 \%)\end{array}$ & $\begin{array}{l}2,098 \\
(2.6 \%)\end{array}$ & $\begin{array}{c}73 \\
(3.6 \%)\end{array}$ \\
\hline 1995 & $\begin{array}{l}12,099 \\
(3.2 \%)\end{array}$ & $\begin{array}{c}887 \\
(1.3 \%)\end{array}$ & $\begin{array}{c}417 \\
(4.2 \%)\end{array}$ & $\begin{array}{l}1,768 \\
(1.0 \%)\end{array}$ & $\begin{array}{c}6,035 \\
(18.1 \%)\end{array}$ & $\begin{array}{l}2,954 \\
(3.1 \%)\end{array}$ & $\begin{array}{c}37 \\
(6.0 \%)\end{array}$ \\
\hline 2001 & $\begin{array}{l}12.975 \\
(3.4 \%)\end{array}$ & $\begin{array}{c}584 \\
(1.0 \%)\end{array}$ & $\begin{array}{c}317 \\
(2.7 \%)\end{array}$ & $\begin{array}{c}1,468 \\
(0.9 \%)\end{array}$ & $\begin{array}{c}6,351 \\
(16.9 \%)\end{array}$ & $\begin{array}{c}3,829 \\
(3.7 \%)\end{array}$ & $\begin{array}{c}394 \\
(12.3 \%)\end{array}$ \\
\hline \multicolumn{8}{|c|}{ TOTAL } \\
\hline 1990 Adj & $\begin{array}{c}304,471 \\
(100 \%)\end{array}$ & $\begin{array}{l}50,314 \\
(100 \%)\end{array}$ & $\begin{array}{c}3,529 \\
(100 \%)\end{array}$ & $\begin{array}{c}138,559 \\
(100 \%)\end{array}$ & $\begin{array}{l}28,397 \\
(100 \%)\end{array}$ & $\begin{array}{l}81,575 \\
(100 \%)\end{array}$ & $\begin{array}{c}2,014 \\
(100 \%)\end{array}$ \\
\hline 1995 & $\begin{array}{c}378,930 \\
(100 \%)\end{array}$ & $\begin{array}{l}66,901 \\
(100 \%)\end{array}$ & $\begin{array}{c}9,860 \\
(100 \%)\end{array}$ & $\begin{array}{l}173,764 \\
(100 \%)\end{array}$ & $\begin{array}{l}33,355 \\
(100 \%)\end{array}$ & $\begin{array}{l}94,362 \\
(100 \%)\end{array}$ & $\begin{array}{c}623 \\
(100 \%)\end{array}$ \\
\hline 2001 & $\begin{array}{c}384,484 \\
(100 \%)\end{array}$ & $\begin{array}{c}60,690 \\
(100 \%)\end{array}$ & $\begin{array}{c}11,676 \\
(100 \%)\end{array}$ & $\begin{array}{l}168,560 \\
(100 \%)\end{array}$ & $\begin{array}{c}37,671 \\
(100 \%)\end{array}$ & $\begin{array}{l}102,165 \\
(100 \%)\end{array}$ & $\begin{array}{c}3,198 \\
(100 \%)\end{array}$ \\
\hline
\end{tabular}

- All tables reporting totals could include some unreported characteristics.

- 1995 VMT and vehicle trips with "To or From Work" as a trip purpose are believed to be overstated.

- Increases in Walk trips in 2001 are due, at least in part, to respondents being explicitly asked to include walk trips, which was not the case in prior surveys.

- In 2001, the mode "Bus" was divided into "Local Public Transit Bus," "Commuter Bus," "Charter/tour bus," and "City to city bus." Only "Local Public Transit Bus" and "Commuter Bus" are included in public transit calculations.

- Note that only the 1990 data have been adjusted to make them more comparable with the 1995 and 2001 data. Thus, there are limits on the conclusions that can be drawn in comparing travel with earlier survey years. The adjustments to 1990 data affect only person trips, vehicle trips, person miles of travel (PMT) and vehicle miles of travel (VMT).

- See Appendix for 2001 figures including 0 to 4 year-olds. 
Although both men and women took fewer trips, on average, in 2001 than in 1995, travel by men decreased at a greater rate than that by women. By 2001, women were equally mobile as men, in terms of the number of trips per person. Trips for family and personal business continued to dominate women's travel.

Table 10

Person Trips per Person by Trip Purpose and Gender Adjusted 1990 and 1995 NPTS, and 2001 NHTS

\begin{tabular}{||l|ccc|ccc||}
\hline \multirow{4}{*}{ Total } & & Women & & \multicolumn{3}{c||}{ Men } \\
& $1990 \mathrm{Adj}$ & 1995 & 2001 & $1990 \mathrm{Adj}$ & 1995 & 2001 \\
\multirow{4}{*}{ To or From Work } & $\mathbf{1 , 4 0 1}$ & $\mathbf{1 , 5 5 8}$ & $\mathbf{1 , 4 9 4}$ & $\mathbf{1 , 3 3 9}$ & $\mathbf{1 , 5 7 9}$ & $\mathbf{1 , 4 9 1}$ \\
& $\mathbf{( 1 0 0 \% )}$ & $\mathbf{( 1 0 0 \% )}$ & $\mathbf{( 1 0 0 \% )}$ & $\mathbf{( 1 0 0 \% )}$ & $\mathbf{( 1 0 0 \% )}$ & $\mathbf{( 1 0 0 \% )}$ \\
Work Related Business & 197 & 229 & 200 & 259 & 327 & 273 \\
& $(14.1 \%)$ & $(14.7 \%)$ & $(13.4 \%)$ & $(19.3 \%)$ & $(20.7 \%)$ & $(18.3 \%)$ \\
Family and Personal Business & 11 & 23 & 25 & 21 & 60 & 66 \\
& $(0.8 \%)$ & $(1.5 \%)$ & $(1.7 \%)$ & $(1.6 \%)$ & $(3.8 \%)$ & $(4.5 \%)$ \\
School/Church & 693 & 786 & 715 & 549 & 648 & 590 \\
& $(49.4 \%)$ & $(50.5 \%)$ & $(47.9 \%)$ & $(41.0 \%)$ & $(41.1 \%)$ & $(39.6 \%)$ \\
Social and Recreational & 132 & 141 & 151 & 123 & 134 & 141 \\
& $(9.4 \%)$ & $(9.1 \%)$ & $(10.1 \%)$ & $(9.2 \%)$ & $(8.5 \%)$ & $(9.5 \%)$ \\
Other & 358 & 375 & 389 & 377 & 406 & 405 \\
& $(25.6 \%)$ & $(24.1 \%)$ & $(26.0 \%)$ & $(28.2 \%)$ & $(25.7 \%)$ & $(27.2 \%)$ \\
\hline \hline
\end{tabular}

Note:

- Note that 2001 data excludes persons aged 0 to 4 since travel by such persons were not included in the 1990 and 1995 surveys.

- 1995 VMT and vehicle trips with "To or From Work" as a trip purpose are believed to be overstated.

- Note that only the 1990 data have been adjusted to make them more comparable with the 1995 and 2001 data. Thus, there are limits on the conclusions that can be drawn in comparing travel with earlier survey years. The adjustments to 1990 data affect only person trips, vehicle trips, person miles of travel (PMT) and vehicle miles of travel (VMT).

- All tables reporting totals could include some unreported characteristics. 
The most striking gender difference in travel is non-work travel. About half of women's travel is for family and personal business (e.g., groceries shopping, taking children to school, or organized sports.) The comparable rate for men is less than $40 \%$.

Figure 2

Distribution of Person Trips per Person by Gender and Trip Purpose 1995 NPTS and 2001 NHTS

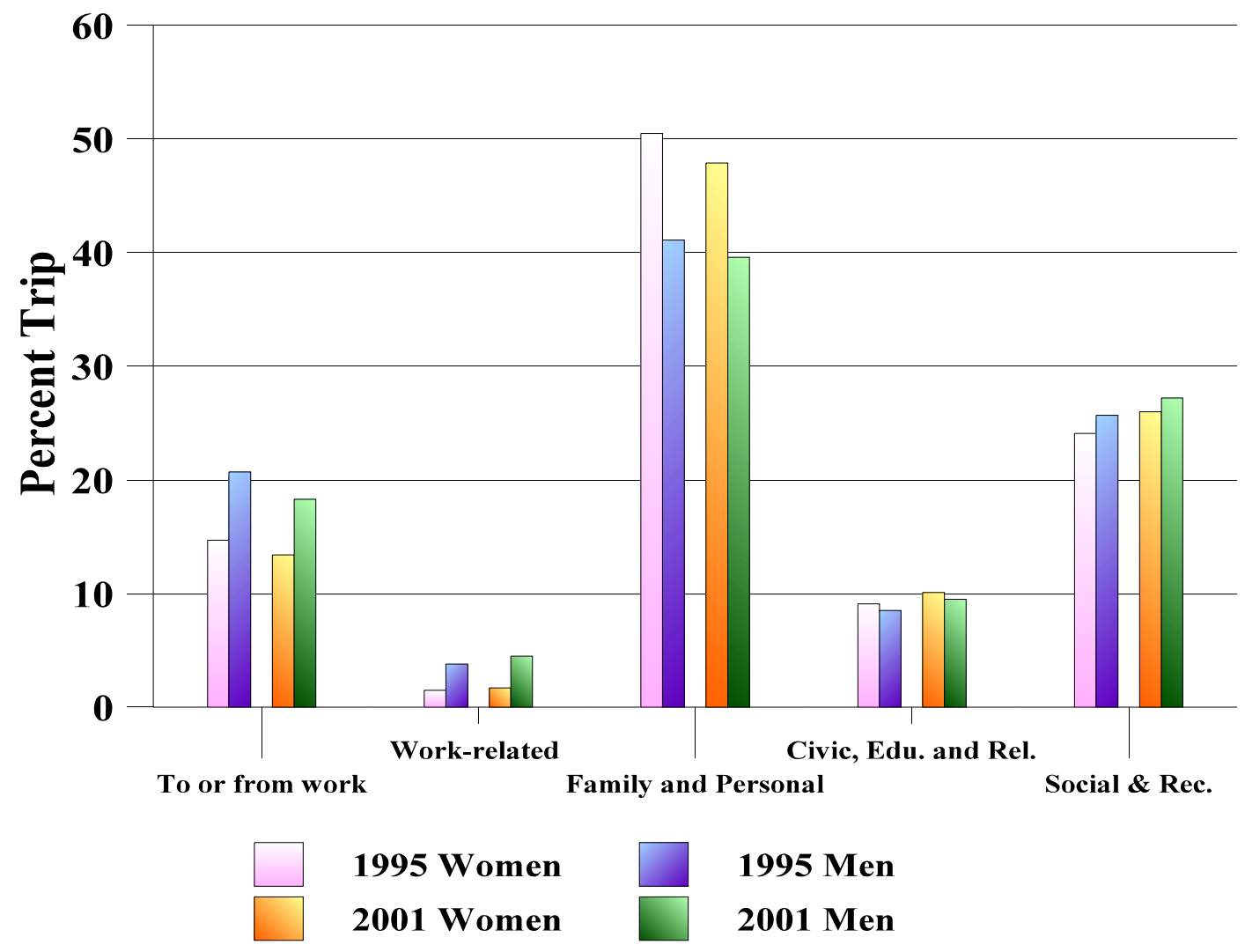


In 2001, a typical American household took fewer, but longer trips than in the previous years. On a per individual basis, the number of person trips per day decreased for the first time since 1977. This decrease might reflect the increase in the number of multi-person households which reduced the need for members in the household to make the same type of trip. On average, a person 5 years or older took about 4 trips a day, representing a 5\% decrease from five years ago. Almost one-half of these trips were for family and personal business.

Table 11

Daily Trip Rates per Person by Trip Purpose 1977, 1983, 1990, 1995 NPTS, and 2001 NHTS

\begin{tabular}{||l|ccc||ccc||}
\hline \multicolumn{1}{|c|}{} & 1977 & 1983 & 1990 & Adjusted 1990 & 1995 & 2001 \\
Total & $\mathbf{2 . 9 2}$ & $\mathbf{2 . 8 9}$ & $\mathbf{3 . 0 8}$ & $\mathbf{3 . 7 6}$ & $\mathbf{4 . 3 0}$ & $\mathbf{4 . 0 9}$ \\
To or From Work & 0.57 & 0.59 & 0.62 & 0.62 & 0.76 & 0.65 \\
Family/Personal Business & 0.91 & 1.02 & 1.28 & 1.71 & 1.97 & 1.79 \\
School/Church & 0.35 & 0.34 & 0.35 & 0.35 & 0.38 & 0.40 \\
Social and Recreational & 0.71 & 0.80 & 0.76 & 1.01 & 1.07 & 1.09 \\
Other & 0.38 & 0.14 & 0.06 & 0.06 & 0.12 & 0.16 \\
Total & $\mathbf{2 5 . 9 5}$ & $\mathbf{2 5 . 0 5}$ & $\mathbf{2 8 . 5 6}$ & $\mathbf{3 4 . 9 1}$ & $\mathbf{3 8 . 6 7}$ & $\mathbf{4 0 . 2 5}$ \\
To or From Work & 5.16 & 5.04 & 6.49 & 6.49 & 8.69 & 7.66 \\
Family/Personal Business & 5.68 & 6.46 & 8.93 & 12.10 & 13.51 & 13.20 \\
School/Church & 1.61 & 1.67 & 1.84 & 1.84 & 2.21 & 2.35 \\
Social and Recreational & 7.81 & 9.85 & 9.86 & 13.02 & 11.86 & 12.09 \\
Other & 5.68 & 2.04 & 1.43 & 1.46 & 2.39 & 4.80 \\
\hline \hline
\end{tabular}

Note:

- All tables reporting totals could include some unreported characteristics.

- Note that 2001 data excludes persons aged 0 to 4 since such persons were not included in the 1990 and 1995 surveys.

- The 1995 "To or From Work" person trips and person miles are believed to be overstated.

- "Other" trip purpose includes trips for work-related business.

- Note that only the 1990 data have been adjusted to make them more comparable with the 1995 and 2001 data. Thus, there are limits on the conclusions that can be drawn in comparing travel with earlier survey years. The adjustments to 1990 data affect only person trips, vehicle trips, person miles of travel (PMT) and vehicle miles of travel (VMT). 
Although taking fewer trips, an individual traveled, on average, slightly more miles per day in 2001 than in 1995. The decreases in daily travel for work and for family and personal business were offset somewhat by the increases in miles traveled for work-related business and for social and recreational trips.

Table 12

Distribution of Daily Person Miles of Travel per Person

by Mode of Transportation and Trip Purpose

Adjusted 1990 and 1995 NPTS, 2001 NHTS

\begin{tabular}{|c|c|c|c|c|c|c|c|c|c|c|c|}
\hline & \multicolumn{2}{|r|}{ Private } & \multicolumn{3}{|c|}{ Public Transit } & \multicolumn{3}{|c|}{ Other } & \multicolumn{3}{|c|}{ TOTAL } \\
\hline & $\begin{array}{c}\text { Adjusted } \\
1990\end{array}$ & 1995 & $\begin{array}{c}\text { Adjusted } \\
1990\end{array}$ & 1995 & 2001 & $\begin{array}{c}\text { Adjusted } \\
1990\end{array}$ & 1995 & 2001 & $\begin{array}{c}\text { Adjusted } \\
1990\end{array}$ & 1995 & 2001 \\
\hline TOTAL & $\begin{array}{c}30.85 \\
(88.4 \%)\end{array}$ & $\begin{array}{cc}35.26 & 35.49 \\
(92.1 \%) & (88.2 \%)\end{array}$ & $\begin{array}{c}0.74 \\
(2.1 \%)\end{array}$ & $\begin{array}{c}0.82 \\
(2.1 \%)\end{array}$ & $\begin{array}{c}0.47 \\
(1.2 \%)\end{array}$ & $\begin{array}{c}3.31 \\
(9.5 \%)\end{array}$ & $\begin{array}{l}2.20 \\
(5.7 \%)\end{array}$ & $\begin{array}{c}4.10 \\
(10.2 \%)\end{array}$ & $\begin{array}{c}34.91 \\
(100 \%)\end{array}$ & $\begin{array}{c}38.67 \\
(100 \%)\end{array}$ & $\begin{array}{c}40.25 \\
(100 \%)\end{array}$ \\
\hline $\begin{array}{l}\text { To or From } \\
\text { Work }\end{array}$ & $\begin{array}{c}6.15 \\
(17.6 \%)\end{array}$ & $\begin{array}{cc}8.09 & 7.11 \\
(20.9 \%) & (17.7 \%)\end{array}$ & $\begin{array}{c}0.27 \\
(0.8 \%)\end{array}$ & $\begin{array}{l}0.30 \\
(0.8 \%)\end{array}$ & $\begin{array}{c}0.24 \\
(0.6 \%)\end{array}$ & $\begin{array}{c}0.06 \\
(0.2 \%)\end{array}$ & $\begin{array}{c}0.22 \\
(0.6 \%)\end{array}$ & $\begin{array}{c}0.30 \\
(0.7 \%)\end{array}$ & $\begin{array}{c}6.49 \\
(18.6 \%)\end{array}$ & $\begin{array}{c}8.69 \\
(22.5 \%)\end{array}$ & $\begin{array}{c}7.66 \\
(19.0 \%)\end{array}$ \\
\hline $\begin{array}{l}\text { Work Related } \\
\text { Business }\end{array}$ & $\begin{array}{c}0.63 \\
(1.8 \%)\end{array}$ & $\begin{array}{cc}1.85 & 2.27 \\
(4.8 \%) & (5.6 \%)\end{array}$ & $\begin{array}{c}0.01 \\
(0.0 \%)\end{array}$ & $\begin{array}{c}0.02 \\
(0.1 \%)\end{array}$ & $\begin{array}{c}0.01 \\
(0.0 \%)\end{array}$ & $\begin{array}{c}0.56 \\
(1.6 \%)\end{array}$ & $\begin{array}{c}0.34 \\
(0.9 \%)\end{array}$ & $\begin{array}{c}1.12 \\
(2.8 \%)\end{array}$ & $\begin{array}{c}1.20 \\
(3.4 \%)\end{array}$ & $\begin{array}{c}2.23 \\
(5.8 \%)\end{array}$ & $\begin{array}{c}3.41 \\
(8.5 \%)\end{array}$ \\
\hline $\begin{array}{c}\text { Family/Personal } \\
\text { Business }\end{array}$ & $\begin{array}{c}11.39 \\
(32.6 \%)\end{array}$ & $\begin{array}{cc}12.70 & 12.77 \\
(32.8 \%) & (31.7 \%)\end{array}$ & $\begin{array}{c}0.14 \\
(0.4 \%)\end{array}$ & $\begin{array}{c}0.19 \\
(0.5 \%)\end{array}$ & $\begin{array}{c}0.10 \\
(0.3 \%)\end{array}$ & $\begin{array}{c}0.57 \\
(1.6 \%)\end{array}$ & $\begin{array}{c}0.49 \\
(1.3 \%)\end{array}$ & $\begin{array}{c}0.32 \\
(0.8 \%)\end{array}$ & $\begin{array}{c}12.10 \\
(34.7 \%)\end{array}$ & $\begin{array}{c}13.51 \\
(34.9 \%)\end{array}$ & $\begin{array}{c}13.20 \\
(32.8 \%)\end{array}$ \\
\hline $\begin{array}{l}\text { School/ } \\
\text { Church }\end{array}$ & $\begin{array}{c}1.32 \\
(3.8 \%)\end{array}$ & $\begin{array}{cc}1.68 & 1.87 \\
(4.3 \%) & (4.6 \%)\end{array}$ & $\begin{array}{c}0.12 \\
(0.3 \%)\end{array}$ & $\begin{array}{c}0.07 \\
(0.2 \%)\end{array}$ & $\begin{array}{c}0.04 \\
(0.1 \%)\end{array}$ & $\begin{array}{c}0.40 \\
(1.1 \%)\end{array}$ & $\begin{array}{c}0.44 \\
(1.1 \%)\end{array}$ & $\begin{array}{c}0.44 \\
(1.1 \%)\end{array}$ & $\begin{array}{c}1.84 \\
(5.3 \%)\end{array}$ & $\begin{array}{c}2.21 \\
(5.7 \%)\end{array}$ & $\begin{array}{l}2.35 \\
(5.8 \%)\end{array}$ \\
\hline $\begin{array}{l}\text { Social and } \\
\text { Recreational }\end{array}$ & $\begin{array}{c}11.12 \\
(31.9 \%)\end{array}$ & $\begin{array}{cc}10.83 & 11.01 \\
(28.0 \%) & (27.3 \%)\end{array}$ & $\begin{array}{c}0.18 \\
(0.5 \%)\end{array}$ & $\begin{array}{c}0.24 \\
(0.6 \%)\end{array}$ & $\begin{array}{c}0.07 \\
(0.2 \%)\end{array}$ & $\begin{array}{c}1.71 \\
(4.9 \%)\end{array}$ & $\begin{array}{c}0.66 \\
(1.7 \%)\end{array}$ & $\begin{array}{c}1.01 \\
(2.5 \%)\end{array}$ & $\begin{array}{c}13.02 \\
(37.3 \%)\end{array}$ & $\begin{array}{c}11.86 \\
(30.7 \%)\end{array}$ & $\begin{array}{c}12.09 \\
(30.0 \%)\end{array}$ \\
\hline Other & $\begin{array}{c}0.23 \\
(0.7 \%)\end{array}$ & $\begin{array}{cc}0.10 & 0.36 \\
(0.3 \%) & (0.9 \%)\end{array}$ & $\begin{array}{c}0.01 \\
(0.0 \%)\end{array}$ & $\begin{array}{c}0.00 \\
(0.0 \%)\end{array}$ & $\begin{array}{c}0.00 \\
(0.0 \%)\end{array}$ & $\begin{array}{c}0.01 \\
(0.0 \%)\end{array}$ & $\begin{array}{c}0.05 \\
(0.1 \%)\end{array}$ & $\begin{array}{c}0.87 \\
(2.2 \%)\end{array}$ & $\begin{array}{c}0.25 \\
(0.7 \%)\end{array}$ & $\begin{array}{c}0.15 \\
(0.4 \%)\end{array}$ & $\begin{array}{c}1.39 \\
(3.5 \%)\end{array}$ \\
\hline
\end{tabular}

Note:

- All tables reporting totals could include some unreported characteristics.

- Note that 2001 data excludes persons aged 0 to 4 since such persons were not included in the 1990 and 1995 surveys.

- In 2001, the mode "Bus" was divided into "Local Public Transit Bus," "Commuter Bus," "Charter/tour bus," and "City to city bus." Only "Local Public Transit Bus" and "Commuter Bus" are included in public transit calculations.

- Note that only the 1990 data have been adjusted to make them more comparable with the 1995 and 2001 data. Thus, there are limits on the conclusions that can be drawn in comparing travel with earlier survey years. The adjustments to 1990 data affect only person trips, vehicle trips, person miles of travel (PMT) and vehicle miles of travel (VMT).

- Numbers in parenthesis are a percentage of total daily person miles of travel. 
Table 13

Average Daily Person Trips per Person by Age and Gender 1983, 1990, 1995 NPTS, and 2001 NHTS

\begin{tabular}{|c|c|c|c|c|c|c|c|c|c|c|c|c|c|c|c|}
\hline \multirow[b]{2}{*}{ Age } & \multicolumn{5}{|c|}{ TOTAL } & \multicolumn{5}{|c|}{ Men } & \multicolumn{5}{|c|}{ Women } \\
\hline & 1983 & 1990 & $\begin{array}{c}1990 \\
\text { Adj }\end{array}$ & 1995 & 2001 & 1983 & 1990 & $\begin{array}{l}1990 \\
\text { Adj }\end{array}$ & 1995 & 2001 & 1983 & 1990 & $\begin{array}{c}1990 \\
\text { Adj }\end{array}$ & 1995 & 2001 \\
\hline Total & 2.9 & 3.1 & 3.8 & 4.3 & 4.1 & 2.9 & 3.0 & \begin{tabular}{|l|l}
3.7 \\
\end{tabular} & 4.3 & 4.1 & 2.9 & 3.1 & 3.8 & 4.3 & 4.1 \\
\hline Under 16 & 2.3 & 2.6 & 3.1 & 3.7 & 3.4 & 2.3 & 2.6 & 3.0 & 3.7 & 3.5 & 2.3 & 2.6 & 3.1 & 3.8 & 3.4 \\
\hline 16 to 20 & 3.3 & 3.5 & 4.2 & 4.6 & 4.1 & 3.2 & 3.5 & 4.2 & 4.6 & 4.0 & 3.4 & 3.5 & 4.2 & 4.7 & 4.2 \\
\hline 21 to 35 & 3.5 & 3.6 & 4.4 & 4.6 & 4.3 & 3.4 & 3.5 & 4.2 & 4.5 & 4.2 & 3.5 & 3.7 & 4.6 & 4.8 & 4.5 \\
\hline 36 to 65 & 2.9 & 3.2 & 3.9 & 4.6 & 4.5 & 2.9 & 3.1 & 3.7 & 4.6 & 4.4 & 3.0 & 3.3 & 4.1 & 4.6 & 4.5 \\
\hline Over 65 & 1.8 & 1.9 & 2.4 & 3.4 & 3.4 & 2.2 & 2.2 & 2.8 & 3.9 & 3.8 & 1.5 & 1.7 & 2.2 & 3.0 & 3.1 \\
\hline
\end{tabular}

Note:

- All tables reporting totals could include some unreported characteristics.

- Note that 2001 data excludes persons aged 0 to 4 since such persons were not included in the 1990 and 1995 surveys.

- Note that only the 1990 data have been adjusted to make them more comparable with the 1995 and 2001 data. Thus, there are limits on the conclusions that can be drawn in comparing travel with earlier survey years. The adjustments to 1990 data affect only person trips, vehicle trips, person miles of travel (PMT) and vehicle miles of travel (VMT). 
As a group, both men and women decreased their travel slightly from five years ago. By 2001, men and women took, on average, an equal number of trips per day (Table 13). The most striking gender difference in travel was among individuals 65 years or older. Women 65 years or older took about $20 \%$ fewer trips than did older men. Between the ages 16 and 65, women took an equal number or more trips than men. This pattern was true for both 1995 and 2001.

Figure 3

Average Daily Person Trips by Age and Gender

From 1995 to 2001

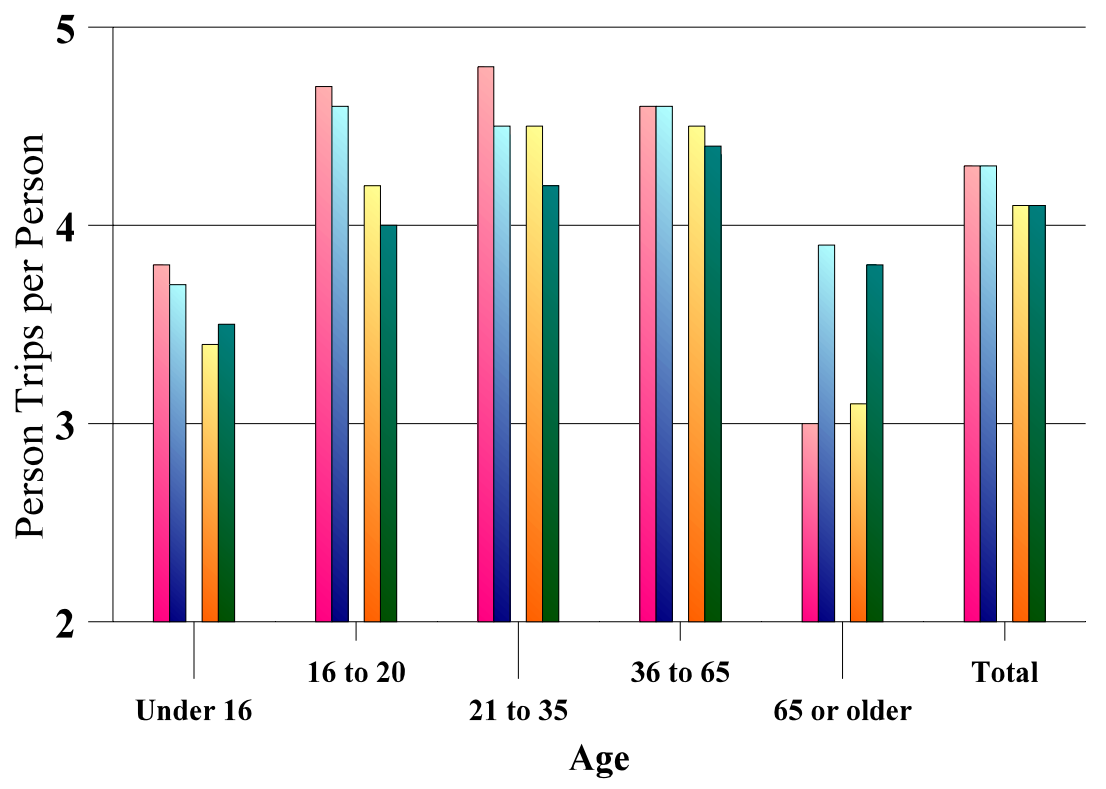

1995 women

1995 men

2001 women 2001 men 
On average, an individual traveled 40 miles per day, with men traveling 10 miles more, on average, than women. As evident in Table 14 and Figure 4, there were significant travel differences between men and women by age. The difference in miles traveled is particularly telling given the fact that men and women took about an equal number of trips per day (Table 13). Women's trips were notably shorter than men's trips.

Table 14

Average Daily Person Miles of Travel per Person by Age and Gender 1983, 1990, 1995 NPTS, and 2001 NHTS

\begin{tabular}{|c|c|c|c|c|c|c|c|c|c|c|c|c|c|c|c|}
\hline \multirow[b]{2}{*}{ Age } & \multicolumn{5}{|c|}{ 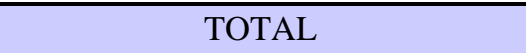 } & \multicolumn{5}{|c|}{ Men } & \multicolumn{5}{|c|}{ Women } \\
\hline & 1983 & 1990 & $\begin{array}{c}1990 \\
\text { Adj }\end{array}$ & 1995 & 2001 & 1983 & 1990 & $\begin{array}{c}1990 \\
\text { Adj }\end{array}$ & 1995 & 2001 & 1983 & 1990 & $\begin{array}{c}1990 \\
\text { Adj }\end{array}$ & 1995 & 2001 \\
\hline Total & 25.1 & 28.6 & 34.9 & 38.7 & 40.2 & 27.7 & 31.6 & 38.0 & 43.9 & 45.0 & 22.6 & 25.8 & 32.1 & 33.8 & 35.7 \\
\hline Under 16 & 16.2 & 16.2 & 20.1 & 25.0 & 24.5 & 16.8 & 16.3 & 20.3 & 23.7 & 24.6 & 15.4 & 16.1 & 19.9 & 26.2 & 24.4 \\
\hline 16 to 20 & 22.2 & 28.1 & 34.4 & 36.4 & 38.1 & 23.0 & 30.1 & 36.9 & 37.6 & 34.1 & 21.5 & 26.2 & 32.2 & 35.0 & 42.5 \\
\hline 21 to 35 & 31.1 & 36.5 & 44.3 & 46.0 & 45.6 & 32.8 & 40.4 & 48.2 & 51.3 & 49.8 & 29.5 & 32.9 & 40.7 & 40.8 & 41.5 \\
\hline 36 to 65 & 29.2 & 33.0 & 40.1 & 45.1 & 48.8 & 33.6 & 36.5 & 43.4 & 53.2 & 57.7 & 25.2 & 29.7 & 37.0 & 37.5 & 40.4 \\
\hline Over 65 & 12.0 & 14.2 & 18.4 & 24.4 & 27.5 & 14.8 & 17.4 & 22.5 & 31.7 & 32.9 & 10.2 & 11.8 & 15.3 & 19.2 & 23.5 \\
\hline
\end{tabular}

Note:

- All tables reporting totals could include some unreported characteristics.

- Note that 2001 data excludes persons aged 0 to 4 since such persons were not included in the 1990 and 1995 surveys.

- Note that only the 1990 data have been adjusted to make them more comparable with the 1995 and 2001 data. Thus, there are limits on the conclusions that can be drawn in comparing travel with earlier survey years. The adjustments to 1990 data affect only person trips, vehicle trips, person miles of travel (PMT) and vehicle miles of travel (VMT). 
Figure 4

Average Daily Person Miles of Travel per Person by Gender 1995 NPTS and 2001 NHTS
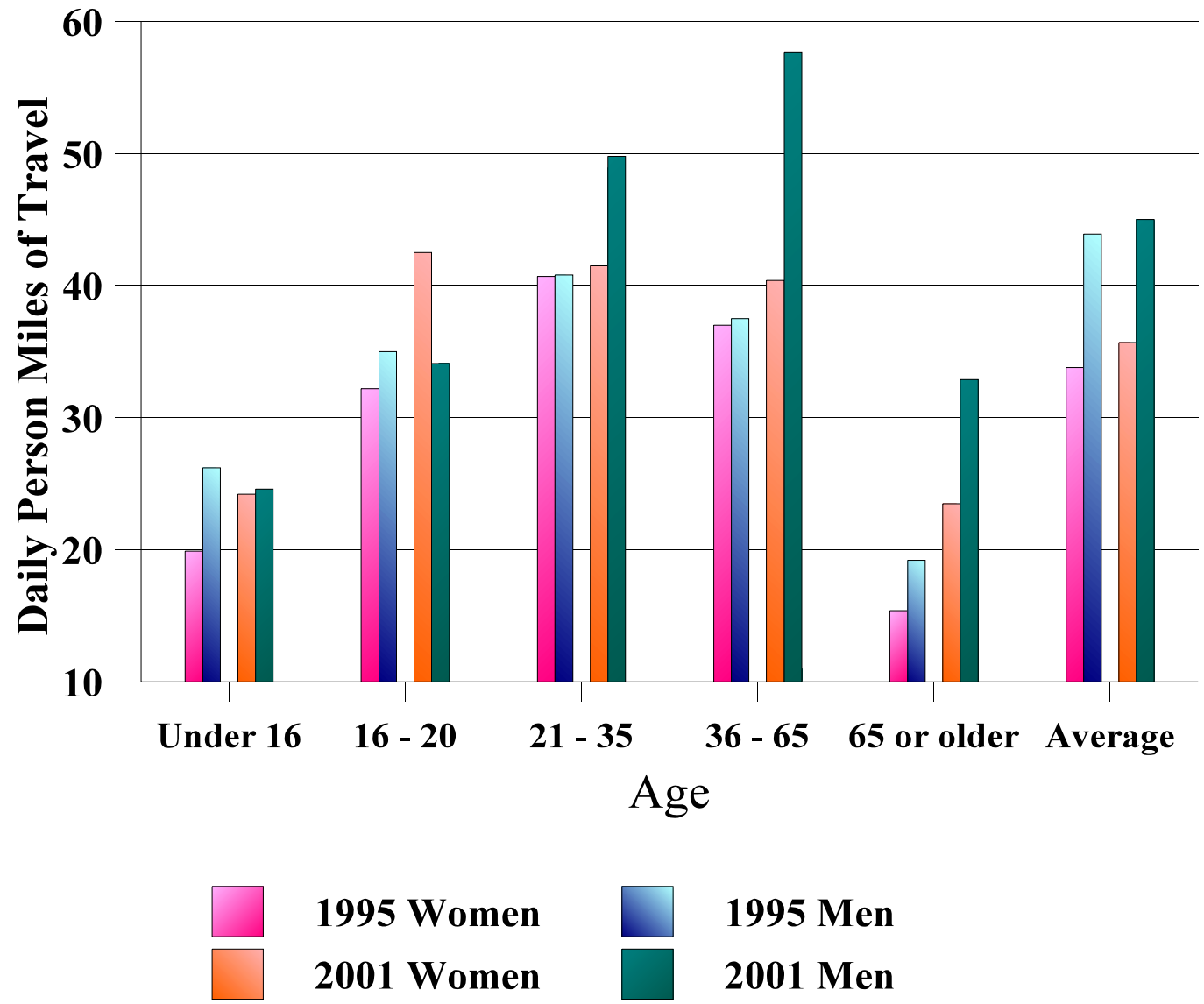
The average amount of time we spent in a vehicle (as a driver or a passenger) in 2001 was slightly more than an hour and varied greatly by an individual's age. Children younger than 5 years old spent three-quarters of an hour a day in vehicles. Compared to 1995, Americans spent about $10 \%$ more time in their vehicles but traveled about the same number of miles (Figure 6).

Figure 5.

Average Time Spent in Vehicle (Minutes) by Age

2001 NHTS

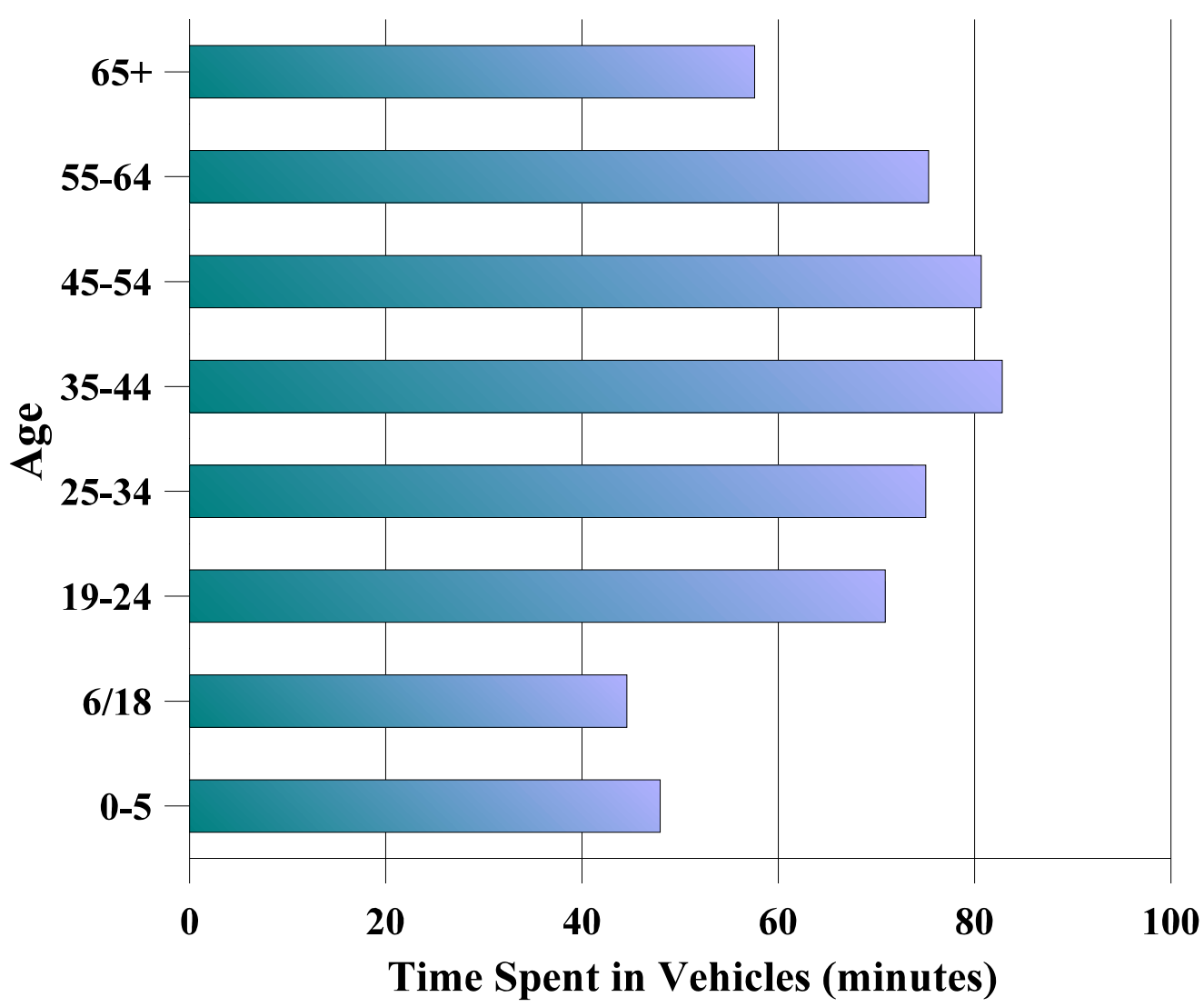


Figure 6

Average Time Spent in Vehicle and Miles Traveled 1995 NPTS and 2001 NHTS

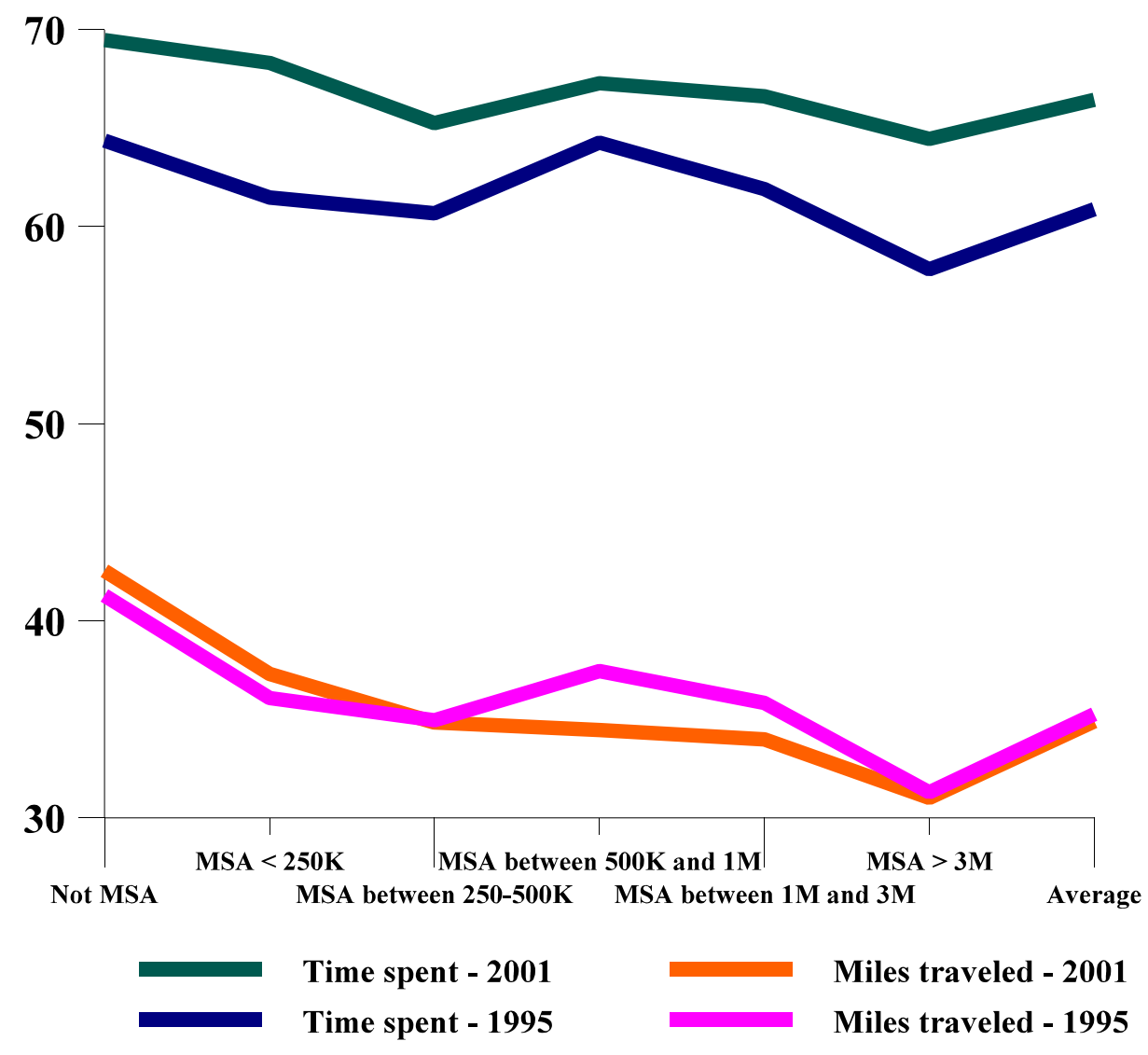


The average time spent driving a private vehicle was calculated using two different methods: 1) by including all drivers, even those who did not drive a private vehicle on the designated travel day, and 2) by excluding any drivers who did not drive on the designated travel day. Note the 1990 data reported here are different from those published in the 1990 Nationwide Personal Transportation Survey Databook, Volume II (Tables 5-66 to 5-68), due to the fact that adjusted data were used for 1990. In 2001, a driver spent on average more than one hour behind the wheel, an increase of 6 minutes from 1995. People living in smaller cities generally spent slightly less time driving than those living in large areas.

Table 15

Average Time Spent Driving a Private Vehicle in a Typical Day by MSA Size Adjusted 1990 and 1995 NPTS, and 2001 NHTS (in Minutes)

\begin{tabular}{||l|ccc||ccc||}
\hline & \multicolumn{3}{|c||}{ All Drivers } & \multicolumn{3}{c||}{$\begin{array}{c}\text { Only Persons Who Drove } \\
\text { on Their Travel Day }\end{array}$} \\
\hline MSA Size & $1990 \mathrm{Adj}$ & 1995 & 2001 & $1990 \mathrm{Adj}$ & 1995 & 2001 \\
ALL & $\mathbf{4 9 . 3 5}$ & $\mathbf{5 6 . 2 0}$ & $\mathbf{6 1 . 2 3}$ & $\mathbf{7 1 . 8 8}$ & $\mathbf{7 3 . 0 7}$ & $\mathbf{8 1 . 3 5}$ \\
Not in MSA & 48.85 & 56.36 & 60.87 & 69.20 & 72.75 & 81.74 \\
$<250,000$ & 48.36 & 53.86 & 59.21 & 67.94 & 69.14 & 76.40 \\
250,000 to 499,999 & 47.82 & 55.81 & 58.71 & 71.66 & 71.49 & 76.50 \\
500,000 to 999,999 & 50.20 & 56.76 & 61.70 & 72.42 & 73.12 & 79.34 \\
1 to 2.9 million & 50.61 & 56.48 & 61.62 & 74.38 & 72.13 & 79.55 \\
$3+$ million & 49.38 & 56.43 & 62.13 & 71.08 & 74.86 & 85.12 \\
\hline \hline
\end{tabular}

Note:

- For 1990 and 1995, average time spent driving does not include any driving done in a segmented trip. Also excludes driving done as an "essential part of work."

- Note that only the 1990 data have been adjusted to make them more comparable with the 1995 and 2001 data. Thus, there are limits on the conclusions that can be drawn in comparing travel with earlier survey years. The adjustments to 1990 data affect only person trips, vehicle trips, person miles of travel (PMT) and vehicle miles of travel (VMT). 
The trend of declining average vehicle occupancy, measured as person miles per vehicle mile, was reversed in 2001. The difference between 1995 and 2001 is statistically significant at $95 \%$ confidence. This trend probably reflects the gasoline price increases. In general, people are less likely to carpool for commutes to and from work, but more likely to share rides for social and recreational trips.

Table 16

Average Vehicle Occupancy for Selected Trip Purposes

1977, 1983, 1990, 1995 NPTS, and 2001 NHTS

(person miles per vehicle mile)

\begin{tabular}{||l|cccccc||}
\hline & 1977 & 1983 & 1990 & 1995 & 2001 & $\begin{array}{c}\text { Percent Change (77 } \\
01)\end{array}$ \\
\cline { 6 - 7 } & & & & & & Total Change \\
Trip Purpose & 1.3 & 1.29 & 1.14 & 1.14 & 1.14 & $-12.31 \%$ \\
To or From Work & 2.1 & 1.79 & 1.71 & 1.74 & 1.79 & $-14.76 \%$ \\
Shopping & 2.0 & 1.81 & 1.84 & 1.78 & 1.83 & $-8.50 \%$ \\
$\begin{array}{l}\text { Other Family or } \\
\text { Personal Business }\end{array}$ & 2.4 & 2.12 & 2.08 & 2.04 & 2.03 & $-15.42 \%$ \\
Social and Recreational & $\mathbf{1 . 9}$ & $\mathbf{1 . 7 5}$ & $\mathbf{1 . 6 4}$ & $\mathbf{1 . 5 9}$ & $\mathbf{1 . 6 3}$ & $\mathbf{- 1 4 . 2 1 \%}$ \\
\hline All Purposes & & & &
\end{tabular}

Note:

- All Purposes includes other trip purposes not shown, such as trips to school, church, doctor, dentist, and work-related business trips. 
More than $60 \%$ of all households had 2 or more vehicles in 2001 . Furthermore, not only were there more multi-vehicle households in 2001 than in 1995, they also owned more vehicles. There was a shift in 2001 from 1- to 2-vehicle households to 3+ vehicle households. Households that owned at least one vehicle owned an average of 2.05 vehicles in 2001, compared to 1.93 in 1995 . The percentage of households without a vehicle remained at the 1995 level, though the number of households without a vehicle increased - from 8 million households in 1995 to more than 8.7 million in 2001.

\section{Table 17}

Availability of Household Vehicles

1969, 1977, 1983, 1990, 1995 NPTS, and 2001 NHTS

(thousands)

\begin{tabular}{||l|cccccc||}
\hline \hline Households with -- & 1969 & 1977 & 1983 & 1990 & 1995 & 2001 \\
No Vehicle & 12,876 & 11,538 & 11,548 & 8,573 & 7,989 & 8,716 \\
& $(20.6 \%)$ & $(15.3 \%)$ & $(13.5 \%)$ & $(9.2 \%)$ & $(8.1 \%)$ & $(8.1 \%)$ \\
One Vehicle & 30,252 & 26,092 & 28,780 & 30,654 & 32,064 & 33,757 \\
& $(48.4 \%)$ & $(34.6 \%)$ & $(33.7 \%)$ & $(32.8 \%)$ & $(32.4 \%)$ & $(31.4 \%)$ \\
Two Vehicles & 16,501 & 25,942 & 28,632 & 35,872 & 40,024 & 39,938 \\
& $(26.4 \%)$ & $(34.4 \%)$ & $(33.5 \%)$ & $(38.4 \%)$ & $(40.4 \%)$ & $(37.2 \%)$ \\
Three or More & 2,875 & 11,840 & 16,411 & 18,248 & 18,914 & 24,955 \\
Vehicles & $(4.6 \%)$ & $(15.7 \%)$ & $(19.2 \%)$ & $(19.6 \%)$ & $(19.1 \%)$ & $(23.2 \%)$ \\
ALL & $\mathbf{6 2 , 5 0 4}$ & $\mathbf{7 5 , 4 1 2}$ & $\mathbf{8 5 , 3 7 1}$ & $\mathbf{9 3 , 3 4 7}$ & $\mathbf{9 8 , 9 9 0}$ & $\mathbf{1 0 7 , 3 6 5}$ \\
& $\mathbf{( 1 0 0 . 0 \% )}$ & $\mathbf{( 1 0 0 . 0 \% )}$ & $\mathbf{( 1 0 0 . 0 \% )}$ & $\mathbf{( 1 0 0 . 0 \% )}$ & $\mathbf{( 1 0 0 . 0 \% )}$ & $\mathbf{( 1 0 0 . 0 \% )}$ \\
\hline \hline Vehicles Per & $\mathbf{1 . 1 6}$ & $\mathbf{1 . 5 9}$ & $\mathbf{1 . 6 8}$ & $\mathbf{1 . 7 7}$ & $\mathbf{1 . 7 8}$ & $\mathbf{1 . 8 9}$ \\
Household & & &
\end{tabular}

Note:

- The 1969 survey does not include pickups or other light trucks as household vehicles. 
There were significantly more households in 2001 than in 1995 who owned a greater number of vehicles than there were drivers in the household. More than eighty percent of the households had at least one vehicle for each of their drivers in 2001. It is clear that income affects vehicle ownership and availability. Three out of every four low-income families did not own a vehicle, while one in two families with household income more than $\$ 55,000$ had more vehicles than licensed drivers in their households.

Figure 7

Household Distribution ${ }^{2}$ by Household Income and Vehicle to Driver Ratio 2001 NHTS

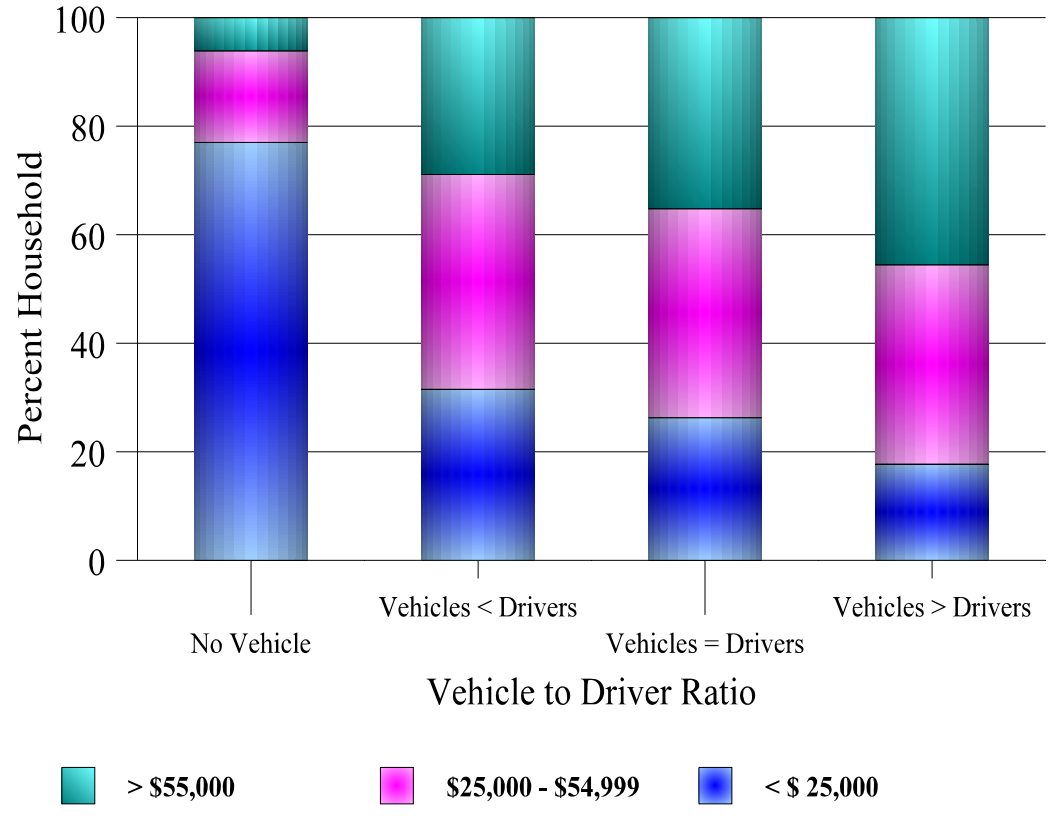

2 Only includes households that reported income information. 
Population density seems to have little or no impact on households' decisions to own a vehicle, except in highly-populated areas with more than ten thousand persons per square mile. Almost thirty percent of the households in areas with a population density greater than 10,000 per square mile did not own a vehicle. On the other hand, almost $70 \%$ of the households in the least densely-populated areas owned more than two vehicles.

Table 18

Distribution of Households by Household Vehicle Availability and Population Density 1990 and 1995 NPTS and 2001 NHTS

\begin{tabular}{|c|c|c|c|c|c|c|c|c|c|c|c|c|}
\hline \multirow{3}{*}{$\begin{array}{l}\text { Household Vehicle } \\
\text { Availability }\end{array}$} & \multicolumn{12}{|c|}{ Population Density (Persons per Square Mile) } \\
\hline & \multicolumn{3}{|c|}{ Less than 2,000} & \multicolumn{3}{|c|}{2,000 to 4,000} & \multicolumn{3}{|c|}{4,000 to 10,000} & \multicolumn{3}{|c|}{10,000 or more } \\
\hline & 1990 & 1995 & 2001 & 1990 & 1995 & 2001 & 1990 & 1995 & 2001 & 1990 & 1995 & 2001 \\
\hline ALL & $100 \%$ & $100 \%$ & $100 \%$ & $100 \%$ & $100 \%$ & $100 \%$ & $100 \%$ & $100 \%$ & $100 \%$ & $100 \%$ & $100 \%$ & $100 \%$ \\
\hline No Vehicle & $6.1 \%$ & $3.9 \%$ & $4.2 \%$ & $7.6 \%$ & $6.2 \%$ & $5.9 \%$ & $10.9 \%$ & $8.5 \%$ & $8.7 \%$ & $35.1 \%$ & $31.0 \%$ & $28.1 \%$ \\
\hline One Vehicle & $30.4 \%$ & $27.3 \%$ & $26.2 \%$ & $33.4 \%$ & $33.8 \%$ & $34.1 \%$ & $38.2 \%$ & $38.6 \%$ & $37.0 \%$ & $40.0 \%$ & $41.7 \%$ & $39.9 \%$ \\
\hline Two Vehicles & $41.0 \%$ & $44.5 \%$ & $40.1 \%$ & $41.5 \%$ & $42.3 \%$ & $38.6 \%$ & $34.9 \%$ & $38.6 \%$ & $36.5 \%$ & $18.4 \%$ & $21.3 \%$ & $23.1 \%$ \\
\hline $\begin{array}{l}\text { Three or More } \\
\text { Vehicles }\end{array}$ & $22.5 \%$ & $24.3 \%$ & $29.5 \%$ & $17.5 \%$ & $17.7 \%$ & $21.4 \%$ & $16.0 \%$ & $14.4 \%$ & $17.7 \%$ & $6.5 \%$ & $6.0 \%$ & $8.9 \%$ \\
\hline
\end{tabular}


Figure 8

Vehicle Ownership and Demographic Statistics by Population Density 2001 NHTS

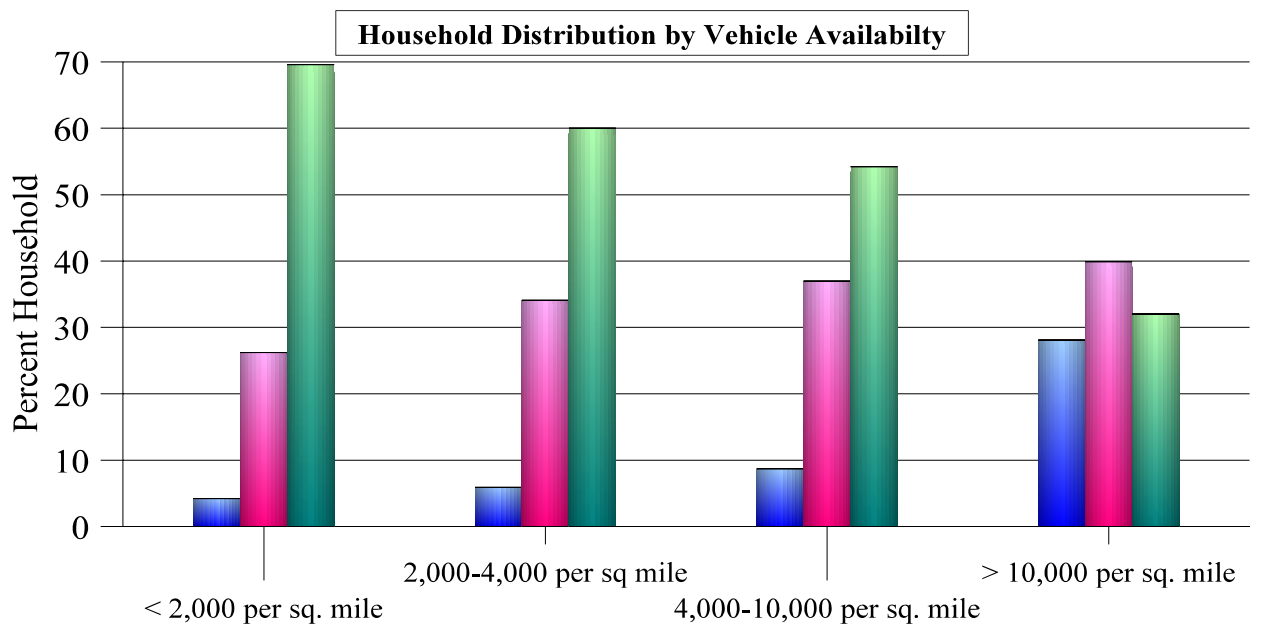

No Vehicle $\quad \square$ One Vehicle $\quad \square$ Multi-Vehicle

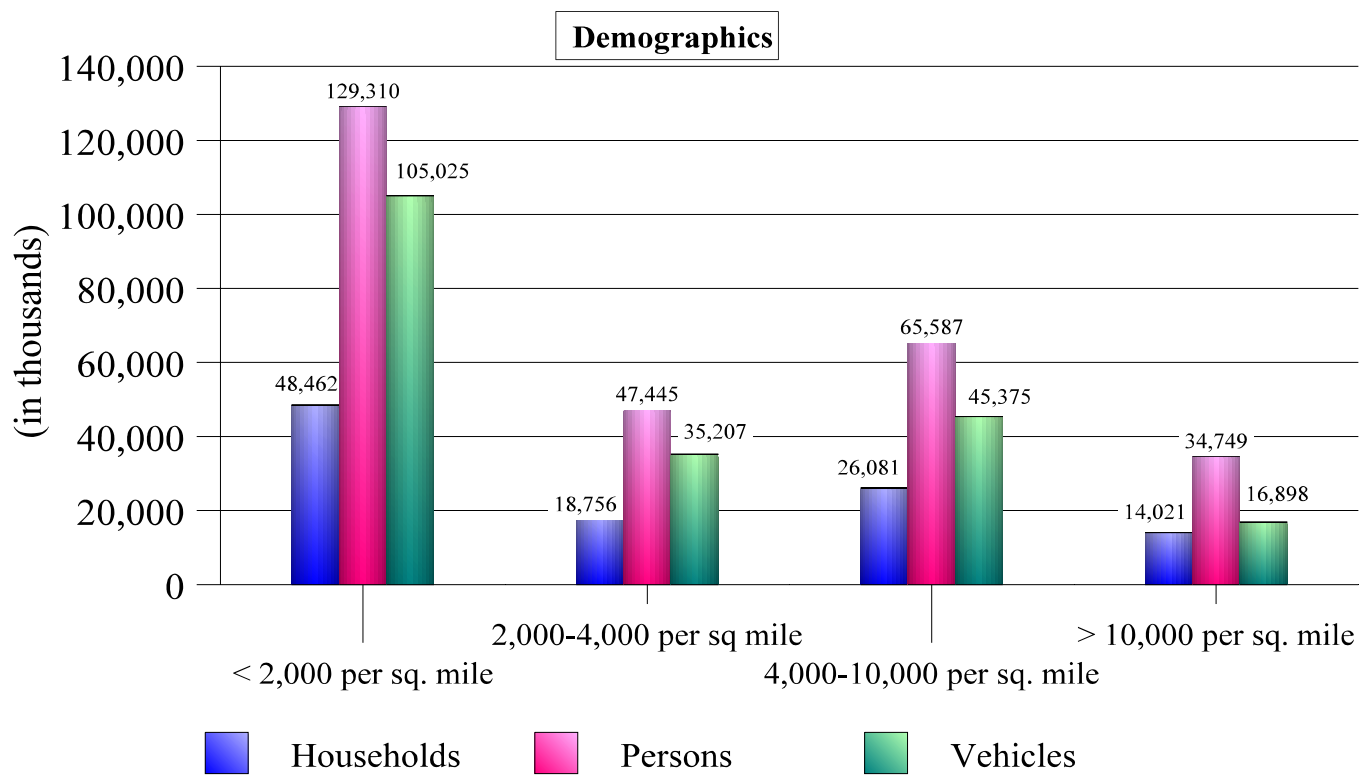


The percentage of households not owning a vehicle increases with increasing area size. In 2001 , about $6 \%$ of the households in non-MSA areas or in small cities $(<250,000)$ were without a vehicle, representing a slight increase from 1995. The comparable percentage for areas with more than 3 million people was close to $12 \%$. In large cities, such as New York, some zerovehicle households are by choice due to the high cost and the inconvenience of owning a vehicle, and the availability of other modes. About 6 to 7 percent of the households in mediumsize cities (with 500,000 to 3 million people) did not have a vehicle.

Table 19

Percent of Households Without a Vehicle Within MSA Size Group 1977, 1983, 1990, 1995 NPTS, and 2001 NHTS

\begin{tabular}{||l|ccccc||c||}
\hline \multirow{2}{*}{ (S)MSA Size } & \multicolumn{6}{|c||}{ \% Households Within An Area Without a Vehicle } \\
\cline { 2 - 7 } & 1977 & 1983 & 1990 & 1995 & 2001 & $\begin{array}{c}\text { \% Change } \\
1977-2001\end{array}$ \\
Not in (S)MSA & 12.2 & 10.5 & 7.7 & 5.3 & 5.8 & $-52 \%$ \\
$<250,000$ & 13.7 & 10.1 & 8.6 & 4.8 & 5.8 & $-58 \%$ \\
250,000 to 499,999 & 12.2 & 8.1 & 5.7 & 7.3 & 5.2 & $-57 \%$ \\
500,000 to 999,999 & 14.0 & 14.3 & 8.4 & 6.3 & 7.0 & $-50 \%$ \\
1 to 2.9 million & 14.2 & 12.1 & 8.2 & 6.9 & 6.4 & $-55 \%$ \\
$3+$ million & 26.1 & 25.4 & 12.4 & 11.2 & 11.9 & $-54 \%$ \\
ALL & $\mathbf{1 5 . 3}$ & $\mathbf{1 3 . 5}$ & $\mathbf{9 . 2}$ & $\mathbf{8 . 1}$ & $\mathbf{8 . 1}$ & $\mathbf{- 4 7 \%}$ \\
\hline \hline
\end{tabular}

Note:

- The population size groups for 1977 - 1983 NPTS are SMSA Size Groups and 1990 - 2001 are MSA Size Groups.

- All tables reporting totals could include some unreported characteristics. 
Automobiles continued to lose their market share of private vehicles, from $80 \%$ in 1977 to less than $60 \%$ in 2001. In the meantime, the market share for sport utility vehicles (SUVs) doubled between 1995 and 2001. Except for SUVs, the average age of vehicles in 2001 was greater than in the past.

Table 20

Vehicle Distribution and Average Vehicle Age by Vehicle Type 1977, 1983, 1990, 1995 NPTS, and 2001 NHTS

\begin{tabular}{||l|ccccc||}
\hline \multicolumn{1}{||}{} & 1977 & \multicolumn{1}{c}{1983} & 1990 & 1995 & 2001 \\
TOTAL & $\mathbf{1 0 0 . 0}$ & $\mathbf{1 0 0 . 0}$ & $\mathbf{1 0 0 . 0}$ & $\mathbf{1 0 0 . 0}$ & $\mathbf{1 0 0 . 0}$ \\
Auto & 79.6 & 75.9 & 74.7 & 64.3 & 56.8 \\
Van & 2.8 & 3.6 & 5.5 & 7.8 & 9.0 \\
Sport Utility & $N A$ & $N A$ & $N A$ & 6.9 & 12.1 \\
Pickup & 12.8 & 15.2 & 17.2 & 17.7 & 18.4 \\
Other Truck & 1.3 & 1.5 & 0.6 & 0.4 & 0.5 \\
RV/Motor Home & 0.4 & 0.5 & 0.5 & 0.5 & 0.7 \\
Motorcycle & 2.7 & 2.5 & 1.3 & 0.9 & 2.1 \\
Moped & 0.2 & 0.6 & 0.1 & $N A$ & $N A$ \\
Other & 0.2 & 0.2 & 0.1 & 0.1 & 0.5 \\
& & Average Vehicle Age & & & \\
TOTAL & $\mathbf{6 . 6}$ & $\mathbf{7 . 6 0}$ & $\mathbf{7 . 7 1}$ & $\mathbf{8 . 3 3}$ & $\mathbf{8 . 8 7}$ \\
Auto & 6.4 & 7.20 & 7.61 & 8.24 & 8.98 \\
Van & 5.5 & 8.45 & 5.88 & 6.68 & 7.56 \\
Sport Utility & NA & NA & NA & 6.56 & 6.44 \\
Pickup & 7.3 & 8.54 & 8.43 & 9.65 & 10.05 \\
Other Truck & 11.6 & 12.39 & 14.48 & 14.93 & 17.72 \\
RV/Motor Home & 4.5 & 10.69 & 10.44 & 13.21 & 13.49 \\
\hline \hline
\end{tabular}

Note:

- The 1977, 1983, and 1990 surveys do not include a separate category for sports utility vehicles, while the 1995 and 2001 surveys do. In 1990 survey, most SUVs were classified as automobiles. The 1995 and 2001 surveys do not include a separate category for mopeds.

- Motorcycle, moped, and other pov are excluded from the calculation of vehicle age.

- All tables reporting totals could include some unreported characteristics. 
In 2001, household vehicles remained in operation significantly longer than those in 1977 . In 1977, automobiles averaged 5.5 years of age while automobiles in 2001 averaged 9 years of age - an increase of almost 3.5 years. In 2001, two out of every five vehicles were at least 10 years old. In the past, trucks and vans tended to be in operation longer than automobiles. However, this trend was no longer true by 2001.

Table 21

Distribution of Vehicles by Vehicle Age and Vehicle Type 1977, 1983, 1990, 1995 NPTS, and 2001 NHTS

(percentage)

\begin{tabular}{|c|c|c|c|c|c|c|c|c|c|c|c|c|c|c|c|}
\hline \multirow[b]{2}{*}{ Vehicle Age } & \multicolumn{3}{|c|}{1977} & \multicolumn{3}{|c|}{1983} & \multicolumn{3}{|c|}{1990} & \multicolumn{3}{|c|}{1995} & \multicolumn{3}{|c|}{2001} \\
\hline & Auto & $\begin{array}{c}\text { Truck/ } \\
\text { Van }\end{array}$ & All & Auto & $\begin{array}{c}\text { Truck/ } \\
\text { Van }\end{array}$ & All & Auto & $\begin{array}{c}\text { Truck/ } \\
\text { Van }\end{array}$ & All & Auto & $\begin{array}{c}\text { Truck/ } \\
\text { Van }\end{array}$ & All & Auto & $\begin{array}{c}\text { Truck/ } \\
\text { Van }\end{array}$ & All \\
\hline 0 to 2 years & 27.3 & 29.9 & 27.8 & 20.0 & 16.6 & 19.2 & 15.6 & 19.7 & 16.6 & 14.9 & 19.2 & 16.2 & 13.27 & 18.59 & 15.41 \\
\hline 3 to 5 years & 30.4 & 25.6 & 29.6 & 28.0 & 26.6 & 27.6 & 27.7 & 27.2 & 27.5 & 21.7 & 21.6 & 21.5 & 20.37 & 23.47 & 21.51 \\
\hline 6 to 9 years & 26.7 & 21.1 & 25.7 & 27.4 & 25.0 & 26.9 & 26.8 & 20.9 & 25.3 & 30.3 & 25.5 & 28.5 & 25.45 & 22.59 & 24.08 \\
\hline $\begin{array}{c}10 \text { or more } \\
\text { years }\end{array}$ & 15.6 & 23.4 & 16.9 & 24.6 & 31.8 & 26.3 & 29.9 & 32.2 & 30.6 & 33.1 & 33.7 & 33.8 & 40.91 & 35.36 & 39.00 \\
\hline Total & 100.0 & 100.0 & 100.0 & 100.0 & 100.0 & 100.0 & 100.0 & 100.0 & 100.0 & 100.0 & 100.0 & 100.0 & 100.0 & 100.0 & 100.0 \\
\hline Average Age & 5.5 & 6.4 & 5.6 & 6.7 & 7.8 & 6.9 & 7.6 & 8.0 & 7.7 & 8.2 & 8.3 & 8.3 & 9.0 & 8.5 & 8.9 \\
\hline
\end{tabular}

Note:

- The 1969 survey does not include pickups and other light trucks as household vehicles.

- Totals do not include any unreported vehicle ages, but do include vehicle types such as motorcycle, RV, etc. that are not shown. 
Figure 9

Distribution of Vehicles by Vehicle Age 1977, 1983, 1990 and 1995 NPTS and 2001 NHTS
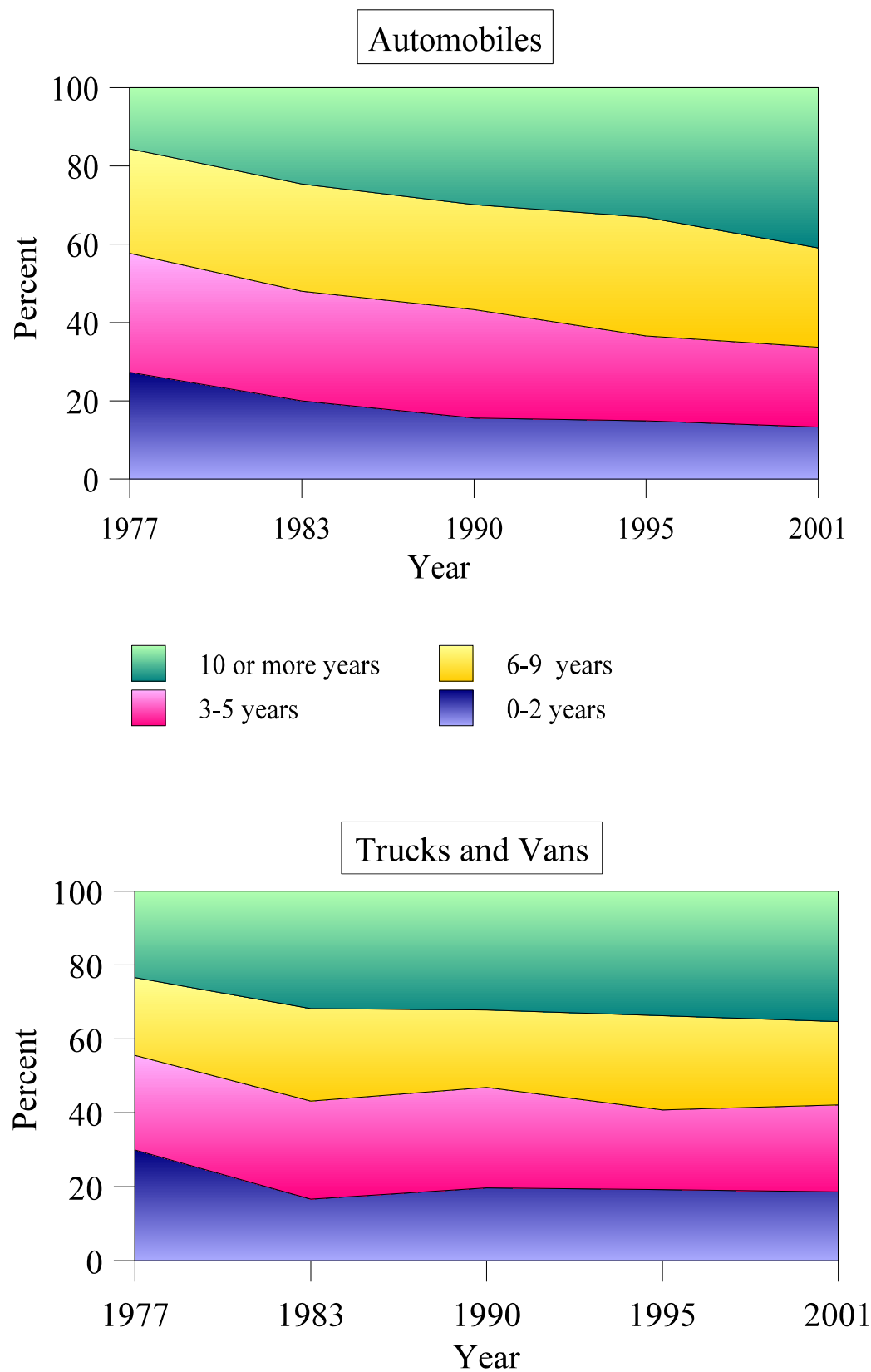
Based on vehicle owners' estimates, a vehicle was driven, on average, slightly more than 11,000 miles a year in 2001, a decrease of $9 \%$ from 1995. Regardless of vehicle age, vehicles were driven less in 2001, on average, than in 1995 or in 1990. Given the trend of more than one vehicle per licensed driver, it is plausible that individual vehicles are being driven less than in previous years.

Table 22

Average Annual Miles per Vehicle by Vehicle Age

(Vehicle Owner's Estimate)

1969, 1977, 1983, 1990, 1995 NPTS, and 2001 NHTS

\begin{tabular}{|c|c|c|c|c|c|c|c|c|}
\hline \multirow[b]{2}{*}{ Vehicle Age } & \multirow[b]{2}{*}{1969} & \multirow[b]{2}{*}{1977} & \multirow[b]{2}{*}{1983} & \multirow[b]{2}{*}{1990} & \multirow[b]{2}{*}{1995} & \multirow[b]{2}{*}{2001} & \multicolumn{2}{|c|}{ "Percent Change } \\
\hline & & & & & & & $\begin{array}{c}\text { Annual } \\
\text { Rate } \\
69-01\end{array}$ & $\begin{array}{r}\text { Total } \\
\text { Change } \\
69-01\end{array}$ \\
\hline 0 to 2 years & 15,700 & 14,460 & 15,292 & 16,811 & 16,092 & 14,892 & $-0.16 \%$ & $-5.15 \%$ \\
\hline 3 to 5 years & 11,200 & 11,074 & 11,902 & 13,706 & 14,004 & 13,230 & $0.52 \%$ & $18.13 \%$ \\
\hline 6 to 9 years & 9,700 & 9,199 & 9,253 & 12,554 & 12,608 & 11,603 & $0.56 \%$ & $19.62 \%$ \\
\hline 10 or more years & 6,500 & 6,755 & 7,023 & 9,176 & 8,758 & 7,863 & $0.60 \%$ & $20.97 \%$ \\
\hline ALL & 11,600 & 10,679 & 10,315 & 12,458 & 12,226 & 11,078 & $-0.14 \%$ & $-4.50 \%$ \\
\hline
\end{tabular}

Note:

- The 1969 survey does not include pickups and other light trucks as household vehicles.

- All tables reporting totals could include some unreported characteristics. 
The number of miles driven per licensed driver continued to increase. On average, drivers in 2001 drove 3,000 miles more per year than those in 1995. This increase was primarily due to the increased driving in 2001 by drivers between 55 and 65 years old compared to the amount of driving by those of similar ages in 1995. The level of teen driving by girls decreased significantly from the 1995 level.

Table 23

Average Annual Miles per Licensed Driver by Driver Age and Gender (Driver's Self Estimate)

1969, 1977, 1983, 1990, 1995 NPTS, and 2001 NHTS

\begin{tabular}{|c|c|c|c|c|c|c|c|c|}
\hline \multirow{3}{*}{ Driver Age } & \multirow{3}{*}{1969} & \multirow{3}{*}{1977} & \multirow{3}{*}{1983} & \multirow{3}{*}{1990} & \multirow{3}{*}{1995} & \multirow{3}{*}{2001} & \multicolumn{2}{|c|}{ Percent Change } \\
\hline & & & & & & & Annual Rate & Total Change \\
\hline & & & & & & & 69-01 & 69-01 \\
\hline \multicolumn{9}{|l|}{ ALL } \\
\hline 16 to 19 & 4,633 & 5,662 & 4,986 & 8,485 & 7,624 & 7,331 & $1.44 \%$ & $58.23 \%$ \\
\hline 20 to 34 & 9,348 & 11,063 & 11,531 & 14,776 & 15,098 & 15,650 & $1.62 \%$ & $67.42 \%$ \\
\hline 35 to 54 & 9,771 & 11,539 & 12,627 & 14,836 & 15,291 & 15,627 & $1.48 \%$ & $59.93 \%$ \\
\hline 55 to 64 & 8,611 & 9,196 & 9,611 & 11,436 & 11,972 & 13,177 & $1.34 \%$ & $53.03 \%$ \\
\hline $65+$ & 5,171 & 5,475 & 5,386 & 7,084 & 7,646 & 7,684 & $1.25 \%$ & $48.60 \%$ \\
\hline ALL & 8,685 & 10,006 & 10,536 & 13,125 & 13,476 & 13,785 & $1.45 \%$ & $58.72 \%$ \\
\hline \multicolumn{9}{|l|}{ Men } \\
\hline 16 to 19 & 5,461 & 7,045 & 5,908 & 9,543 & 8,206 & 8,228 & $1.29 \%$ & $50.67 \%$ \\
\hline 20 to 34 & 13,133 & 15,222 & 15,844 & 18,310 & 17,976 & 18,634 & $1.10 \%$ & $41.89 \%$ \\
\hline 35 to 54 & 12,841 & 16,097 & 17,808 & 18,871 & 18,858 & 19,287 & $1.28 \%$ & $50.20 \%$ \\
\hline 55 to 64 & 10,696 & 12,455 & 13,431 & 15,224 & 15,859 & 16,883 & $1.44 \%$ & $57.84 \%$ \\
\hline $65+$ & 5,919 & 6,795 & 7,198 & 9,162 & 10,304 & 10,163 & $1.70 \%$ & $71.70 \%$ \\
\hline ALL & 11,352 & 13,397 & 13,962 & 16,536 & 16,550 & 16,920 & $1.26 \%$ & $49.05 \%$ \\
\hline \multicolumn{9}{|l|}{ Women } \\
\hline 16 to 19 & 3,586 & 4,036 & 3,874 & 7,387 & 6,873 & 6,106 & $1.68 \%$ & $70.27 \%$ \\
\hline 20 to 34 & 5,512 & 6,571 & 7,121 & 11,174 & 12,004 & 12,266 & $2.53 \%$ & $122.53 \%$ \\
\hline 35 to 54 & 6,003 & 6,534 & 7,347 & 10,539 & 11,464 & 11,590 & $2.08 \%$ & $93.07 \%$ \\
\hline 55 to 64 & 5,375 & 5,097 & 5,432 & 7,211 & 7,780 & 8,795 & $1.55 \%$ & $63.63 \%$ \\
\hline $65+$ & 3,664 & 3,572 & 3,308 & 4,750 & 4,785 & 4,803 & $0.85 \%$ & $31.09 \%$ \\
\hline ALL & 5,411 & 5,940 & 6,382 & 9,528 & 10,142 & 10,233 & $2.01 \%$ & $89.11 \%$ \\
\hline
\end{tabular}

Note:

- All tables reporting totals could include some unreported characteristics.

- In 1995, some drivers indicating that they drove 'no miles' for their average annual miles were changed to 'miles not reported.' 
Table 24

Commute VMT and Total VMT By Year

1969, 1977, 1983, 1990, 1995 NPTS, and 2001 NHTS

\begin{tabular}{||l|cccc||ccc||}
\hline \hline $\begin{array}{l}\text { Commute Vehicle Trips } \\
(000,000)\end{array}$ & 1969 & 1977 & 1983 & 1990 & 1990 adj & 1995 & 2001 \\
\hline $\begin{array}{l}\text { Commute VMT (000,000) } \\
\text { Total VMT (000,000) } \\
\% \text { Commute VMT of Total } \\
\text { VMT }\end{array}$ & 27,844 & 31,886 & 35,271 & 41,792 & 41,792 & 54,782 & 51,395 \\
\hline $\begin{array}{l}\text { Workers (000) } \\
\text { Annual Commute Vehicle }\end{array}$ & $33.60 \%$ & $31.70 \%$ & $30.10 \%$ & $32.14 \%$ & $26.72 \%$ & $31.07 \%$ & $27.02 \%$ \\
Trips per Worker & 75,758 & 93,019 & 103,244 & 118,343 & 118,343 & 131,697 & 145,272 \\
\hline
\end{tabular}

Note:

- 1995 VMT and vehicle trips with "To or From Work" as a trip purpose are believed to be overstated.

- Caution should be used when comparing the number of workers or the number of commute trips between the 1990 and 1995 NPTS. Slightly different approaches were used in defining workers and commute trips between the 1990 and 1995 NPTS. 
Figure 10

Distribution of Workers by Usual Mode

1995 NPTS and 2001 NHTS

(percentage)

1995

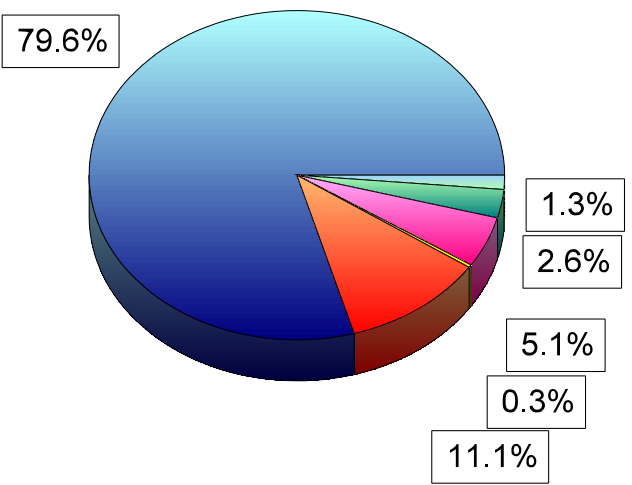

Auto, Truck, Van , or U.V. - Usually Drive Alone

Auto, Truck, Van, or U.V. - Usually Carpool

Auto, Truck, Van , or U.V. - Carpool Status Unknown

Public Transit

Walk

Other

\section{1}

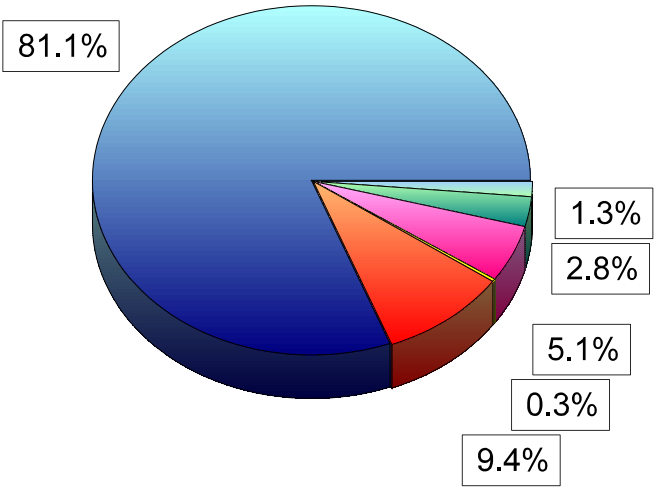


Workers in the U.S. predominately traveled to work in privately-owned vehicles. About 5\% of the commuters reported public transit as their usual mode to work. This percentage has remained at about this level since 1983.

Table 25

Distribution of Workers by Usual Mode 1969, 1977, 1983, 1990, 1995 NPTS, and 2001 NHTS

(percentage)

\begin{tabular}{||l|cccccc||}
\hline Mode of Transportation & 1969 & 1977 & 1983 & 1990 & 1995 & 2001 \\
All Modes & $\mathbf{1 0 0 . 0}$ & $\mathbf{1 0 0 . 0}$ & $\mathbf{1 0 0 . 0}$ & $\mathbf{1 0 0 . 0}$ & $\mathbf{1 0 0 . 0}$ & $\mathbf{1 0 0 . 0}$ \\
Auto, Truck, Van, or Utility Vehicle & 90.8 & 87.0 & 88.6 & 87.8 & 91.0 & 90.8 \\
Public Transit & 8.4 & 6.0 & 5.3 & 5.3 & 5.1 & 5.1 \\
Walk & N/A & 4.1 & 4.3 & 4.0 & 2.6 & 2.8 \\
Other & 0.8 & 2.9 & 1.8 & 2.9 & 1.3 & 1.3 \\
\hline \hline
\end{tabular}

Note:

- Usual mode is defined as the means of transportation usually used to go to work during the week before the interview. Data in this table are derived from the person file.

- The 1969 survey excludes walk trips.

- All modes does not include workers who worked at home or any unreported modes.

- Other includes other modes not shown above such as RV, motorcycle, other POV, Amtrak, airplane, taxi, bike, school bus, and other. 
Table 26

General Commute Patterns by Mode of Transportation 1983, 1990, 1995 NPTS, and 2001 NHTS

\begin{tabular}{|c|c|c|c|c|c|c|c|c|c|c|c|c|c|c|}
\hline 1983 & 1990 & 1995 & 2001 & $1983 \quad 1990$ & 1995 & 2001 & 1983 & 1990 & 1995 & 2001 & 1983 & 1990 & 1995 & 2001 \\
\hline \multicolumn{4}{|c|}{ ALL MODES } & \multicolumn{3}{|c|}{ Private } & \multicolumn{4}{|c|}{ Public Transit } & \multicolumn{4}{|c|}{ Walk } \\
\hline \multicolumn{15}{|c|}{ Average Commute Trip Length (miles) } \\
\hline 8.54 & 10.65 & 11.63 & 12.11 & 8.86 & 1 & 10 & 1 & 75 & 12.88 & 11.73 & 0.32 & 0.83 & 0.74 & 0.91 \\
\hline \multicolumn{15}{|c|}{ Average Commute Travel Time (minutes) } \\
\hline 18.20 & 19.60 & 20.65 & 23.32 & $17.62 \quad 19.05$ & 20.10 & 22.49 & 39.77 & 41.10 & 41.95 & 47.89 & 8.58 & 9.79 & 10.86 & 14.06 \\
\hline \multicolumn{15}{|c|}{ Average Commute Speed (miles per hour) } \\
\hline 28.28 & 33.35 & 34.67 & 32.23 & $30.28 \quad 34.70$ & 35.18 & 32.27 & 17.96 & 17.90 & 19.57 & - & 2.21 & 3.25 & 3.58 & 3.18 \\
\hline
\end{tabular}

Note:

- All Public Transit trips in 2001 had an access or egress recorded, which is equivalent to a 1990 or 1995 segmented trip. For this reason, average commute speed for these trips was not computed, and average commute travel time information may not be comparable to that of previous years.

- All trip miles and travel times were calculated using actual trips to and from work as reported in the travel day file.

- Average Commute Speed was calculated using only those trips with both trip mileage and travel time information present.

- Average commute trip length for 1990, 1995, and 2001 was calculated using only those records with trip mileage information present.

- Average commute travel time does not include time spent waiting for transportation. In the 2001 NHTS, this involved subtracting the number of minutes waiting for public transit (TRWAITTM) from the number of minutes to complete entire trip (TRVL_MIN).

- Average commute speed for 1990 and 1995 NPTS does not include any segmented trips because a change in the mode of transportation during the trip would cause the calculation of average commute speed to be meaningless.

- In 2001, the mode "Bus" was divided into "Local Public Transit Bus," "Commuter Bus," "Charter/tour bus," and "City to city bus." Only "Local Public Transit Bus" and "Commuter Bus" are included in public transit calculations.

- All tables reporting totals could include some unreported characteristics. Air, taxi, bicycle, school bus, "Other", and unreported vehicle types are excluded from the listed categories but included in "ALL MODES" totals for all years. From 1990, Amtrak is also included in totals but excluded from listed categories. In 2001, several new vehicle definitions are also omitted from listed categories but included in totals: charter bus, city to city bus, ship/cruise, passenger line/ferry, sailboat/motorboat/yacht, limousine, and hotel/airport shuttle. 
The average distance for commutes in privately-owned vehicles has remained relatively constant since 1995. However, the average commute time increased by more than $10 \%$ from 1995 to 2001, reflecting slower commute speeds and greater congestion (Tables 26 and 27). This was true regardless of where people lived (Figure 11). Compared to 1995, the commute distances by public transit in 2001 were shorter, but took more time.

Figure 11

Average Commute Time in Privately-Owned Vehicles and MSA Size 1995 NPTS and 2001 NHTS

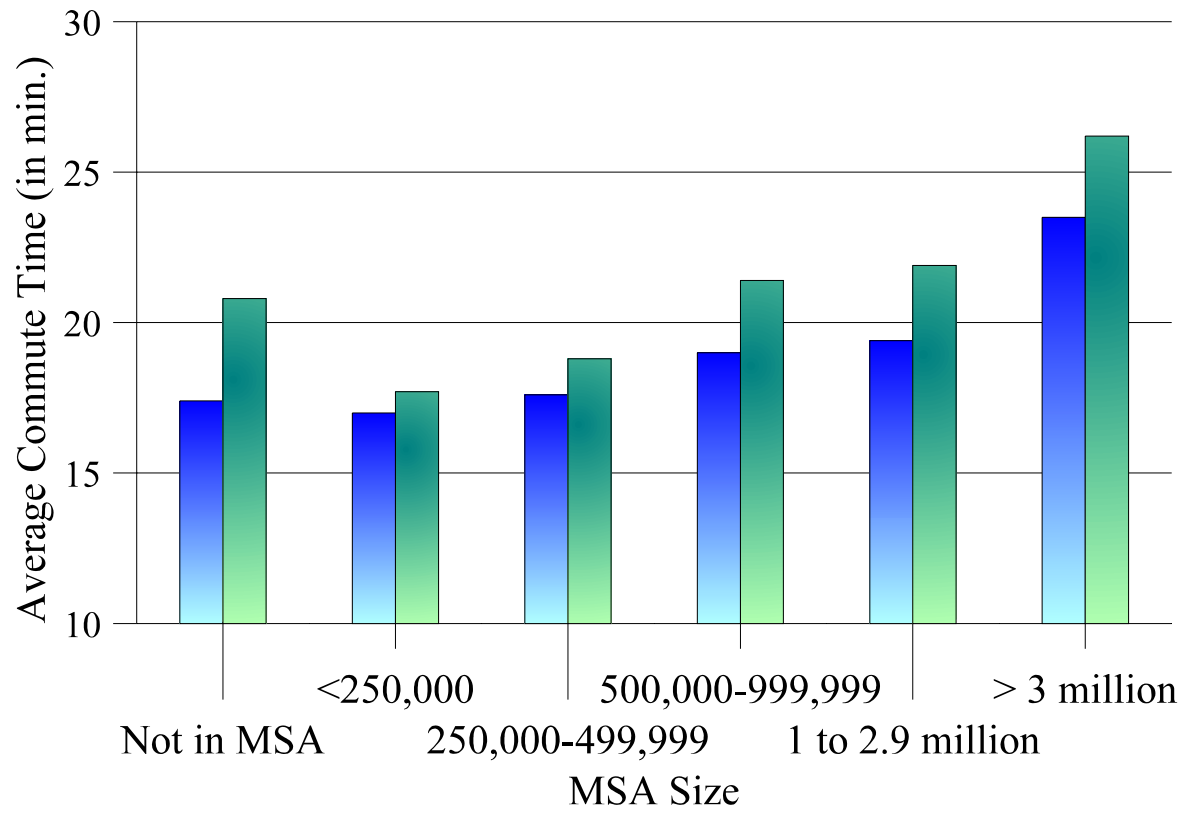

1995

2001 
Table 27

Average Commute Speed by MSA Size 1983, 1990, 1995 NPTS, and 2001 NHTS

(miles per hour)

\begin{tabular}{||l|cccccc||}
\hline \multicolumn{1}{||c|}{} & \multicolumn{7}{|c||}{ MSA Size } \\
\cline { 2 - 8 } & $\begin{array}{c}\text { Not in } \\
\text { (S)MSA }\end{array}$ & $\begin{array}{c}\text { Less than } \\
250,000\end{array}$ & $\begin{array}{c}250,000 \text { to } \\
499,999\end{array}$ & $\begin{array}{c}500,000 \text { to } \\
999,999\end{array}$ & $\begin{array}{c}1 \text { to } 2.9 \\
\text { million }\end{array}$ & $\begin{array}{c}3 \text { million and } \\
\text { over }\end{array}$ \\
1983 & 33.44 & 28.28 & 30.14 & 29.91 & 30.00 & 28.37 \\
1990 & 39.07 & 34.39 & 34.77 & 35.60 & 33.33 & 32.81 \\
1995 & 39.53 & 36.55 & 35.21 & 35.36 & 34.11 & 33.43 \\
2001 & 38.18 & 33.31 & 32.02 & 33.45 & 31.22 & 29.69 \\
& & ALL MODES (INCLUDING POV) & & \\
1983 & 32.23 & 27.26 & 30.08 & 28.52 & 28.09 & 24.51 \\
1990 & 37.82 & 33.66 & 34.14 & 34.60 & 32.35 & 30.92 \\
1995 & 38.90 & 35.85 & 35.98 & 35.25 & 34.62 & 32.41 \\
2001 & 37.69 & 32.78 & 31.46 & 33.70 & 30.84 & 30.24 \\
\hline \hline
\end{tabular}

Note:

- Average Commute Speed is calculated using only those trips with both trip mileage and travel time information present

- All trip miles and travel times were calculated using actual trips to and from work as reported in the travel day file.

- Average commute speed for 1990 and 1995 NPTS does not include any segmented trips because a change in the mode of transportation during the trip would cause the calculation of average commute speed to be meaningless.

- Trips involving an access to or egress from public transit in 2001 were excluded.

- The population size groups for 1977 - 1983 NPTS are SMSA Size Groups and 1990 - 2001 are MSA Size Groups. 
In almost all areas, average commute speeds have decreased since 1995 (Table 27). Generally, as the population of an area increases, commute speeds decrease. Depending on the time of day and location, average commute speeds ranged widely. In larger areas, commute speeds start to decline in mid-afternoon and continue to decline well into the early evening.

Figure 12

Average Commute Speed for Selected Time of Day by MSA Size 2001 NHTS

(miles per hour)

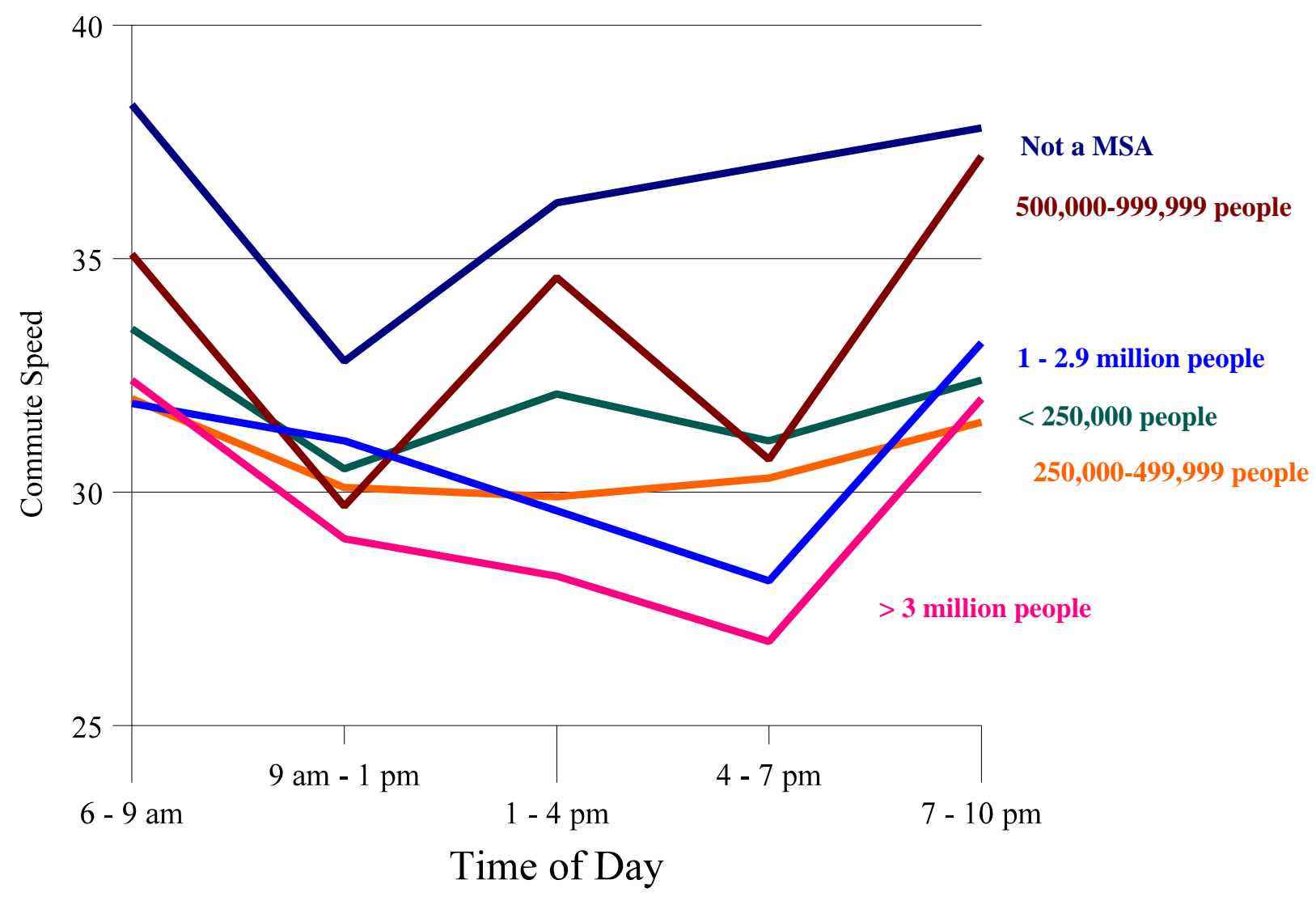


The temporal distribution of personal trips remained the same during the past decade - more than two-fifths of the trips started between 9 o'clock in the morning and 4 o'clock in the afternoon. However, this distribution varies somewhat by trip purpose (see Figure 13). As expected, commuting to and from work began predominately between 6 and 9 o'clock in the morning and between 4 and 7 o'clock in the afternoon while more than half of work-related trips started between 9 am and 4 pm.

Table 28

Distribution of Person Trips by Start Time of Trip 1983, 1990, 1995 NPTS, and 2001 NHTS

\begin{tabular}{|c|c|c|c|c|c|}
\hline Time of Day & 1983 & 1990 & $\begin{array}{r}1990 \\
\text { Adj }\end{array}$ & 1995 & 2001 \\
\hline $10 \mathrm{pm}-1 \mathrm{am}$ & 4.0 & 4.0 & 4.1 & 3.5 & 2.9 \\
\hline $1-6$ am & 3.3 & 1.9 & 1.8 & 1.7 & 1.8 \\
\hline $6-9$ am & 14.4 & 13.9 & 12.5 & 13.8 & 14.4 \\
\hline $9 \mathrm{am}-1 \mathrm{pm}$ & 23.4 & 20.1 & 20.6 & 24.2 & 24.6 \\
\hline $1-4 \mathrm{pm}$ & 20.8 & 20.4 & 20.7 & 22.1 & 22.1 \\
\hline $4-7 \mathrm{pm}$ & 21.2 & 22.8 & 22.9 & 23.0 & 22.3 \\
\hline $7-10 \mathrm{pm}$ & 12.3 & 12.8 & 13.2 & 11.8 & 11.7 \\
\hline ALL & 100.0 & 100.0 & 100.0 & 100.0 & 100.0 \\
\hline
\end{tabular}

Note:

- All tables reporting totals could include some unreported characteristics.

- Note that only the 1990 data have been adjusted to make them more comparable with the 1995 and 2001 data. Thus, there are limits on the conclusions that can be drawn in comparing travel with earlier survey years. The adjustments to 1990 data affect only person trips, vehicle trips, person miles of travel (PMT) and vehicle miles of travel (VMT).

- See Appendix for 2001 figures including 0 to 4 year-olds. 
Figure 13

Distribution of Person Trips by Trip Purpose and Start Time of Trip 2001 NHTS

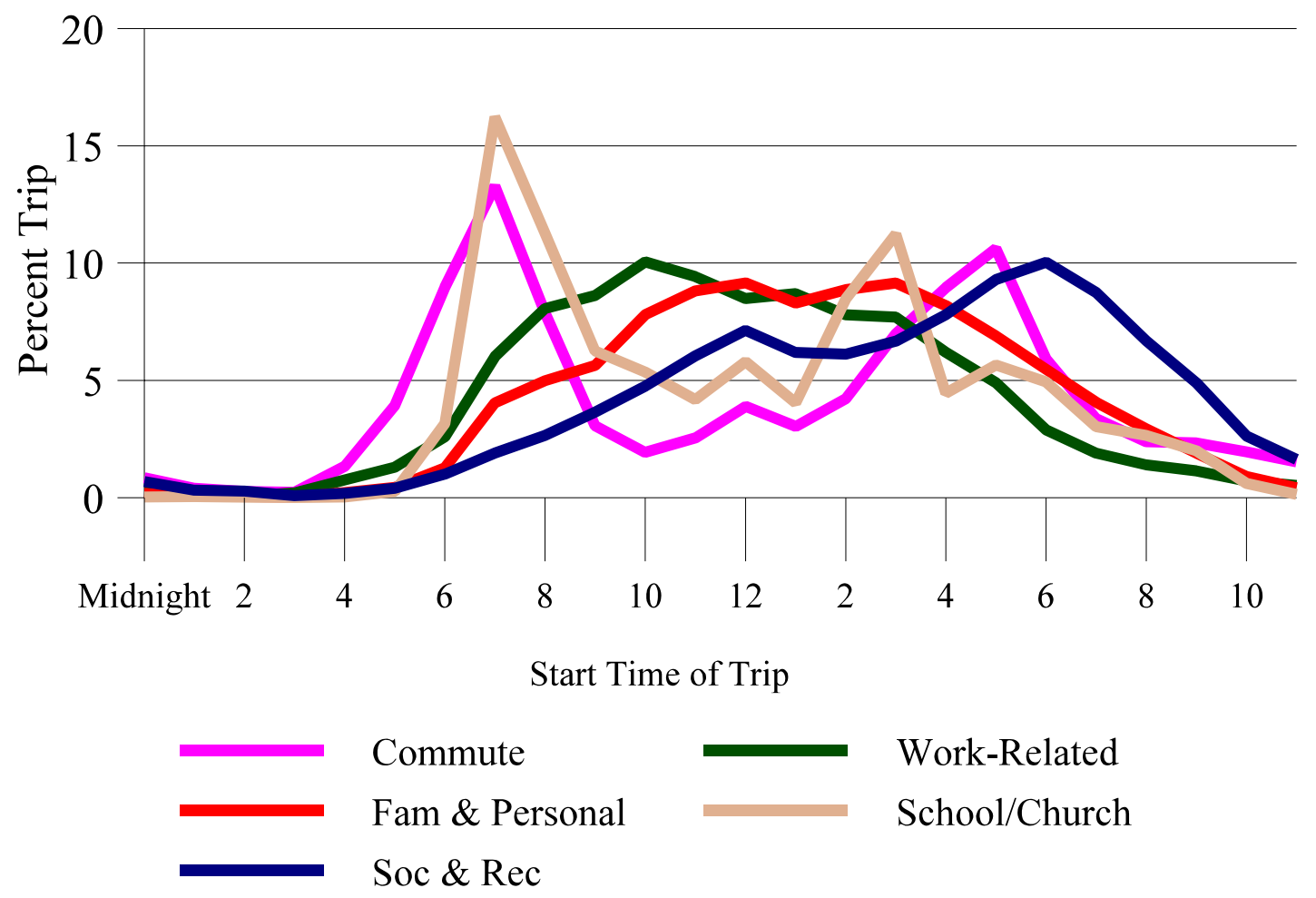


Although travel was less frequent on weekends than on weekdays, weekend trips were on average longer than weekday trips. This has been true since 1990. Compared to 1995, the average time spent driving in 2001 was longer regardless of weekdays or weekends.

Table 29

Daily Travel Statistics by Weekday vs Weekend Adjusted 1990, 1995 NPTS, and 2001 NHTS

\begin{tabular}{||l|cc|cc|cc||}
\hline \hline \multirow{2}{*}{ Daily Travel Statistics } & \multicolumn{2}{|c|}{ 1990 Adjusted } & \multicolumn{2}{|c|}{1995} & \multicolumn{2}{c||}{2001} \\
\cline { 2 - 7 } & Weekday & Weekend & Weekday & Weekend & Weekday & Weekend \\
Vehicle Trips per Driver & 3.41 & 2.89 & 3.81 & 2.99 & 3.56 & 2.85 \\
\% work trips & $27.8 \%$ & $9.7 \%$ & $31.9 \%$ & $12.5 \%$ & $31.2 \%$ & $10.6 \%$ \\
VMT per Driver & $72.2 \%$ & $90.3 \%$ & $68.1 \%$ & $87.5 \%$ & $68.8 \%$ & $89.4 \%$ \\
Average Vehicle Trip & 28.54 & 28.36 & 33.46 & 28.87 & 34.35 & 28.70 \\
Length & 8.47 & 9.96 & 8.85 & 9.73 & 9.75 & 10.22 \\
$\begin{array}{l}\text { Average Time Spent } \\
\text { Driving (in minutes) }\end{array}$ & 50.68 & 46.07 & 59.48 & 48.05 & 64.79 & 52.39 \\
\hline $\begin{array}{l}\text { Person Trips per Person } \\
\text { PMT per Person }\end{array}$ & 3.82 & 3.60 & 4.43 & 3.96 & 4.18 & 3.86 \\
$\begin{array}{l}\text { Average Person Trip } \\
\text { Length }\end{array}$ & 9.47 & 11.51 & 8.63 & 10.53 & 9.60 & 11.18 \\
\hline
\end{tabular}

Note:

- Average time spent driving includes all drivers, even those who did not drive a private vehicle on the day in which the household was interviewed. It does not include any driving done in a segmented trip. Also excludes driving done as an "essential part of work."

- Average trip length is calculated using only those records with trip mileage information present.

- Note that only the 1990 data have been adjusted to make them more comparable with the 1995 and 2001 data. Thus, there are limits on the conclusions that can be drawn in comparing travel with earlier survey years. The adjustments to 1990 data affect only person trips, vehicle trips, person miles of travel (PMT) and vehicle miles of travel (VMT).

- For Tables 28 and 29, “\% Work Trips" also includes Work-Related Business 
On a daily basis, individuals 65 and older took fewer but longer trips in 2001 than in 1995. On average, an elderly driver spent almost fifty minutes a day behind the wheel, representing an increase of 14\% from 1995. Work trips became less common in 2001.

Table 30

Daily Travel Statistics of People 65 and Older 1983, 1990, 1995 NPTS, and 2001 NHTS

\begin{tabular}{||l|cc||ccc||}
\hline Daily Travel Statistics & 1983 & 1990 & $\begin{array}{c}1990 \\
\text { Adjusted }\end{array}$ & 1995 & 2001 \\
Vehicle Trips per Driver & 1.66 & 1.78 & 2.27 & 2.94 & 2.84 \\
$\%$ work trips & $10.2 \%$ & $6.2 \%$ & $4.8 \%$ & $8.5 \%$ & $6.2 \%$ \\
VMT per Driver & $89.8 \%$ & $93.8 \%$ & $95.2 \%$ & $91.5 \%$ & $93.8 \%$ \\
Average Vehicle Trip Length & 9.80 & 11.50 & 14.83 & 19.56 & 21.13 \\
Average Time Spent Driving & $\mathrm{NA}$ & 24.02 & 30.83 & 42.89 & 49.11 \\
(in minutes) & 1.82 & 1.95 & 2.49 & 3.43 & 3.42 \\
\hline Person Trips per Person & 12.21 & 15.33 & 19.85 & 25.24 & 28.04 \\
PMT per Person & 6.70 & 7.99 & 8.12 & 7.46 & 8.35 \\
\hline Average Person Trip Length & & &
\end{tabular}

Note:

- Average time spent driving includes all drivers, even those who did not drive a private vehicle on the day in which the household was interviewed. It does not include any driving done in a segmented trip. Also excludes driving done as an "essential part of work."

- Average trip length is calculated using only those records with trip mileage information present.

- Note that only the 1990 data have been adjusted to make them more comparable with the 1995 and 2001 data. Thus, there are limits on the conclusions that can be drawn in comparing travel with earlier survey years. The adjustments to 1990 data affect only person trips, vehicle trips, person miles of travel (PMT) and vehicle miles of travel (VMT).

- For Tables 29 and 30, "\% Work Trips" also includes Work-Related Business. 
Regardless of household demographic composition, women took more trips in 1995 than in 2001. Single women with children between the ages 6 and 15 averaged more than 5 trips per day. The proportion of work trips women took increased two percentage points from 1995 to 2001.

Table 31

Daily Person Trips of Adult Women by Household Composition 1983, 1990, 1995 NPTS, and 2001 NHTS

\begin{tabular}{||l|c|c||c|c|c||}
\hline \multirow{2}{*}{ Household Composition } & 1983 & 1990 & $\begin{array}{c}\text { Adjusted } \\
1990\end{array}$ & 1995 & 2001 \\
\cline { 2 - 6 } ALL & $\mathbf{2 . 9 5}$ & $\mathbf{3 . 2 3}$ & $\mathbf{4 . 0 0}$ & $\mathbf{4 . 3 6}$ & $\mathbf{4 . 2 5}$ \\
\hline S work trips & $17.6 \%$ & $17.7 \%$ & $14.3 \%$ & $15.8 \%$ & $17.8 \%$ \\
\hline Single Adult, No Child & 2.60 & 3.32 & 4.07 & 4.19 & 4.26 \\
Single Adult, Child $<6$ & 2.85 & 3.29 & 4.01 & 4.19 & 4.15 \\
2 or > Adult, Child<6 & 2.65 & 3.59 & 4.48 & 4.80 & 4.68 \\
Single Adult, Child 6-15 & 3.32 & 3.51 & 4.41 & 4.74 & 4.55 \\
2 or > Adult, Child 6-15 & 3.73 & 4.17 & 5.17 & 5.35 & 5.18 \\
Single Adult, Child 16-21 & 3.59 & 3.85 & 4.78 & 5.24 & 4.87 \\
2 or > Adult, Child 16-21 & 2.59 & 3.41 & 4.17 & 4.56 & 4.67 \\
Single Adult, Retired & 2.84 & 3.40 & 4.13 & 4.54 & 4.43 \\
2 or > Adult, Retired & 1.49 & 1.79 & 2.30 & 3.06 & 3.26 \\
\hline \hline
\end{tabular}

Note:

- All tables reporting totals could include some unreported characteristics.

- In 1983, adult women were defined as all females 16 or older. In 1990, 1995, and 2001, adult women were defined as females 18 or older.

- Note that only the 1990 data have been adjusted to make them more comparable with the 1995 and 2001 data. Thus, there are limits on the conclusions that can be drawn in comparing travel with earlier survey years. The adjustments to 1990 data affect only person trips, vehicle trips, person miles of travel (PMT) and vehicle miles of travel (VMT). 
Similar to those in higher income households, individuals with low income took fewer trips in 2001 than in 1995. However, individuals in low-income households continued to be less mobile and took fewer trips to, or related to, work when compared to those in higher income households.

Table 32

Daily Person Trips per Person for Low Income Households by Trip Purpose 1983, 1990, and 1995 NPTS

\begin{tabular}{|c|c|c|c|c|c|c|c|}
\hline \multirow{2}{*}{ Trip Purpose } & \multicolumn{5}{|c|}{$\begin{array}{l}\text { Low-Income Households } \\
\text { (Less than } \$ 25,000 \text { of } 2001 \text { dollars) }\end{array}$} & \multicolumn{2}{|c|}{$\begin{array}{c}\text { Other } \\
\text { Households }\end{array}$} \\
\hline & 1983 & 1990 & $\begin{array}{c}\text { Adjusted } \\
1990\end{array}$ & 1995 & 2001 & 1995 & 2001 \\
\hline ALL & $\begin{array}{c}2.44 \\
(100.0 \%)\end{array}$ & $\begin{array}{c}2.77 \\
(100.0 \%)\end{array}$ & $\begin{array}{c}3.40 \\
(100.0 \%)\end{array}$ & $\begin{array}{c}3.79 \\
(100.0 \%)\end{array}$ & $\begin{array}{c}3.52 \\
(100.0 \%)\end{array}$ & $\begin{array}{c}4.57 \\
(100.0 \%)\end{array}$ & $\begin{array}{c}4.32 \\
(100.0 \%)\end{array}$ \\
\hline To/From Work & $\begin{array}{c}0.46 \\
(18.7 \%)\end{array}$ & $\begin{array}{c}0.48 \\
(17.5 \%)\end{array}$ & $\begin{array}{c}0.49 \\
(14.3 \%)\end{array}$ & $\begin{array}{c}0.57 \\
(15.1 \%)\end{array}$ & $\begin{array}{c}0.46 \\
(13.0 \%)\end{array}$ & $\| \begin{array}{c}0.85 \\
(18.7 \%)\end{array}$ & $\begin{array}{c}0.72 \\
(16.6 \%)\end{array}$ \\
\hline Work Related Business & $\begin{array}{c}0.06 \\
(2.4 \%)\end{array}$ & $\begin{array}{c}0.02 \\
(0.9 \%)\end{array}$ & $\begin{array}{c}0.03 \\
(0.8 \%)\end{array}$ & $\begin{array}{c}0.06 \\
(1.6 \%)\end{array}$ & $\begin{array}{c}0.07 \\
(2.1 \%)\end{array}$ & $\mid \begin{array}{c}0.14 \\
(3.0 \%)\end{array}$ & $\begin{array}{c}0.14 \\
(3.3 \%)\end{array}$ \\
\hline Fami & $\begin{array}{c}0.89 \\
(36.3 \%)\end{array}$ & $\begin{array}{c}1.20 \\
(43.3 \%)\end{array}$ & $\begin{array}{c}1.60 \\
(47.1 \%)\end{array}$ & $\begin{array}{c}1.84 \\
(48.5 \%)\end{array}$ & $\begin{array}{c}1.67 \\
(47.3 \%)\end{array}$ & $\mid \begin{array}{c}2.05 \\
(44.8 \%)\end{array}$ & $\begin{array}{c}1.86 \\
(42.9 \%)\end{array}$ \\
\hline School/Church & $\begin{array}{c}0.29 \\
(12.0 \%)\end{array}$ & $\begin{array}{c}0.35 \\
(12.6 \%)\end{array}$ & $\begin{array}{c}0.35 \\
(10.3 \%)\end{array}$ & $\begin{array}{l}0.35 \\
(9.3 \%)\end{array}$ & $\begin{array}{c}0.41 \\
(11.5 \%)\end{array}$ & $\begin{array}{c}0.39 \\
(8.5 \%)\end{array}$ & $\begin{array}{c}0.41 \\
(9.3 \%)\end{array}$ \\
\hline Social \& Recreational & $\begin{array}{c}0.69 \\
(28.2 \%)\end{array}$ & $\begin{array}{c}0.69 \\
(24.9 \%)\end{array}$ & $\begin{array}{c}0.91 \\
(26.8 \%)\end{array}$ & $\begin{array}{c}0.96 \\
(25.3 \%)\end{array}$ & $\begin{array}{c}0.89 \\
(25.3 \%)\end{array}$ & $\begin{array}{c}1.13 \\
(24.7 \%)\end{array}$ & $\begin{array}{c}1.16 \\
(26.8 \%)\end{array}$ \\
\hline Other & $\begin{array}{c}0.06 \\
(2.4 \%)\end{array}$ & $\begin{array}{c}0.02 \\
(0.8 \%)\end{array}$ & $\begin{array}{c}0.02 \\
(0.7 \%)\end{array}$ & $\begin{array}{c}0.00 \\
(0.1 \%)\end{array}$ & $\begin{array}{c}0.02 \\
(0.7 \%)\end{array}$ & $\begin{array}{c}0.01 \\
(0.2 \%)\end{array}$ & $\begin{array}{c}0.04 \\
(0.9 \%)\end{array}$ \\
\hline
\end{tabular}

Note:

- Incomes for 1983, 1990, and 1995 have been adjusted to 2001 dollars.

- Low income households are defined as a household earning $\$ 25,000$ or less in a year.

- All tables reporting totals could include some unreported characteristics.

- Note that only the 1990 data have been adjusted to make them more comparable with the 1995 and 2001 data. Thus, there are limits on the conclusions that can be drawn in comparing travel with earlier survey years. The adjustments to 1990 data affect only person trips, vehicle trips, person miles of travel (PMT) and vehicle miles of travel (VMT). 
In 2001, people in households without a vehicle averaged 1.3 fewer trips per day than those in households with vehicles. The impact of owning a vehicle on mobility was the least for those who lived in large cities. As depicted in Figure 14, almost three-quarters of the trips taken by those who lived in the largest metropolitan areas and who were without a vehicle were by walk, bike or public transit. In general, those without access to a privately-owned vehicle met many of their transportation needs by riding as a passenger in a privately-owned vehicle, or by walking or bicycling (Figure 14).

\section{Table 33}

Daily Person Trips per Person

by Vehicle Ownership Status and MSA Size

Adjusted 1990, 1995 NPTS, and 2001 NHTS

\begin{tabular}{||l|cc|cc|cc||}
\hline \multirow{3}{*}{ MSA Size } & \multicolumn{3}{|c|}{1990 Adjusted } & \multicolumn{2}{c||}{1995} & \multicolumn{2}{c||}{2001} \\
\cline { 2 - 8 } ALL & Without & With & Without & With & Without & With \\
Not in MSA & Vehicle & Vehicles & Vehicle & Vehicles & Vehicle & Vehicles \\
$<250,000$ & $\mathbf{2 . 2 8}$ & $\mathbf{3 . 8 6}$ & $\mathbf{3 . 0 4}$ & $\mathbf{4 . 3 8}$ & $\mathbf{2 . 7 9}$ & $\mathbf{4 . 1 6}$ \\
250,000 to 499,999 & 1.81 & 3.80 & 2.92 & 4.43 & 2.61 & 4.06 \\
500,000 to 999,999 & 2.87 & 4.11 & 2.43 & 4.54 & 2.51 & 4.45 \\
1 to 2.9 million & 1.92 & 3.95 & 3.17 & 4.47 & 2.56 & 4.21 \\
3 million + & 1.80 & 3.98 & 2.69 & 4.45 & 2.69 & 4.28 \\
\hline
\end{tabular}

Note:

- $\quad$ Note that only the 1990 data have been adjusted to make them more comparable with the 1995 and 2001 data. Thus, there are limits on the conclusions that can be drawn in comparing travel with earlier survey years. The adjustments to 1990 data affect only person trips, vehicle trips, person miles of travel (PMT) and vehicle miles of travel (VMT). 
Figure 14

Mode Distribution of Person Trips Taken by Zero-Vehicle Households 2001 NHTS
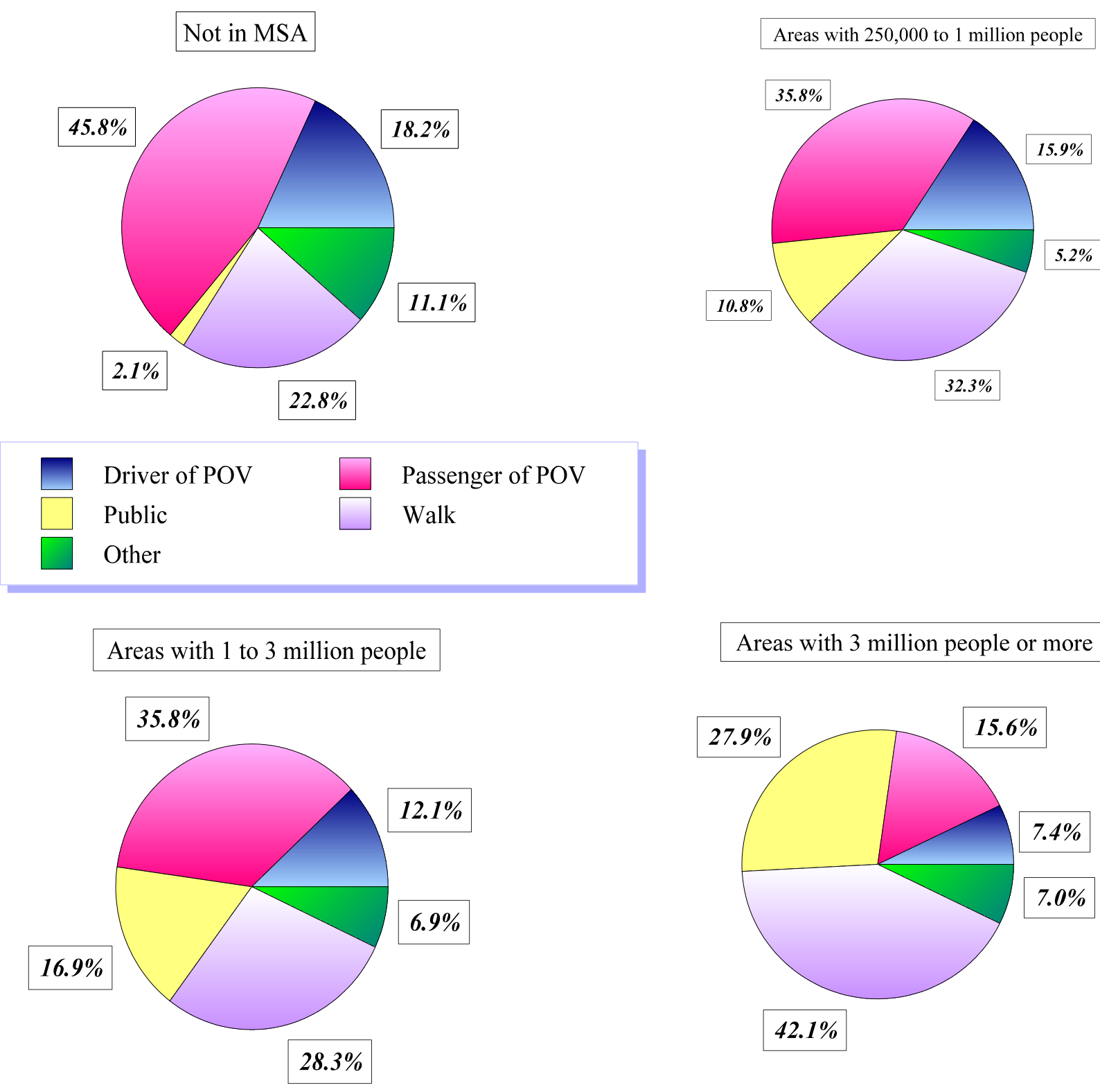


\section{TRAVEL CONCEPTS AND GLOSSARY OF TERMS}

G-1 
This page intentionally left blank.

G-2 


\section{TRAVEL CONCEPTS}

PERSON TRIP DEFINITION -A trip by one person in any mode of transportation. This is the most basic and universal measure of personal travel. Each record in the Travel Day and Travel Period files in the NHTS dataset represents one person trip.

EXAMPLES - Two household members traveling together in one car are counted as two person trips. Three household members walking to the store together are counted as three person trips.

\section{PERSON \\ MILES OF \\ TRAVEL (PMT)}

DEFINITION - The number of miles traveled by each person on a trip.

EXAMPLES - If two people traveling together take a six-mile subway trip to the airport, that trip results in 12 person miles of travel. A fourmile van trip with a driver and three passengers counts as 16 person miles of travel (4 people times 4 miles). 
VEHICLE TRIPS

VEHICLE MILES OF TRAVEL (VMT)
DEFINITION - A trip by a single privately operated vehicle (POV) regardless of the number of persons in the vehicle.

EXAMPLES - Two people traveling together in a car would be counted as one vehicle trip. Four people going to a restaurant in a van is considered one vehicle trip.

NPTS MODE RESTRICTIONS - To be considered a vehicle trip in NHTS, the trip must have been made in a POV, namely a householdbased car, van, sport utility vehicle, pickup truck, other truck, recreational vehicle, motorcycle or other POV. The vehicle does not need to belong to the household.

Trips made in other highway vehicles, such as buses, streetcars, taxis, and school buses are collected in the NHTS, but these are shown as person trips by those modes. The design of the NHTS is such that it does not serve as a source for vehicle trips in modes such as buses, because there is no way to trace the movement of the bus fleet throughout the day. Those interested in vehicle trips by buses, taxis, etc. need to use a data source that relies on reports from the fleet operators of those vehicles. The National Transit Database of the Federal Transit Administration is one such source.

DEFINITION - One vehicle mile of travel is the movement of one privately operated vehicle (POV) for one mile, regardless of the number of people in the vehicle.

EXAMPLES - When one person drives her car 12 miles to work, 12 vehicle miles of travel have been made. If two people travel three miles by pickup, three vehicle miles of travel have been made.

SAME MODE RESTRICTIONS - For NHTS data, vehicle miles are restricted to the same privately-operated vehicles as vehicle trips(see above), that is a household-based car, van, sport utility vehicle, pickup truck, other truck, recreational vehicle, or other POV. 
VEHICLE OCCUPANCY
DEFINITION - For NHTS data, vehicle occupancy is generally computed as person miles of travel per vehicle mile (referred to as the travel method). Note that the other commonly-used definition of vehicle occupancy is persons per vehicle trip (referred to as the trip method) .

COMMENTS - Because longer trips often have higher occupancies, the travel method generally yields a higher rate than the trip method. The calculation of the travel method requires that trip miles be reported, thus it is calculated on a slightly smaller number of trips than the trip method. 


\section{GLOSSARY}

This glossary provides the most common terms used in the NHTS and definitions of those terms. These definitions are provided to assist the user in the interpretation of the NHTS data.

Adult

For NHTS, this is defined as a person 18 years or older.

Block Group A subdivision of a Census tract that averages 1000 to 1100 people, and approximately 400-500 housing units. The source used for the 2001 NHTS was GDT Dynamap 2000 (from Census 2000 TIGER/Line files). 
Census Region and Division

\section{Census Tract}

The Census Bureau divides the states into four regions and nine divisions. Note that the divisions are wholly contained within a region, i.e., region lines do not split division lines. The regions and their component divisions are:

Northeast Region:

1. New England Division: Connecticut, Maine, Massachusetts, New Hampshire, Rhode Island, Vermont

2. Middle Atlantic Division: New Jersey, New York, Pennsylvania North Central Region:

1. East North Central Division: Illinois, Indiana, Michigan, Ohio, Wisconsin

2. West North Central Division: Iowa, Kansas, Minnesota, Missouri, Nebraska, North Dakota, South Dakota

South Region

1. South Atlantic Division: Delaware, Florida, Georgia, Maryland, North Carolina, South Carolina, Virginia, West Virginia

2. East South Central Division: Alabama, Kentucky, Mississippi, Tennessee

3. West South Central Division: Arkansas, Louisiana, Oklahoma, Texas

West Region

1. Mountain Division: Arizona, Colorado, Idaho, Montana, Nevada, New Mexico, Utah, Wyoming

2. Pacific Division: Alaska, California, Hawaii, Oregon, Washington

Puerto Rico

For the 2001 NHTS the source used for the 2000 Census Region was: http://www.census.gov/geo/www/cob/rg2000.html

The source used for the 2000 Census Division was: http://www.census.gov/geo/www/cob/dv2000.html

A small subdivision of a county, containing approximately 4,000 persons. Tracts can range in population from 2,500 to 8,000. The geographic size of the tract may vary considerably, depending on population density. Tracts were designed to be homogeneous in regard to population characteristics, economic status and living conditions when they were first delineated. Since the first tracts were delineated for the 1890 Census, today's tracts may be far from homogeneous. The source used for the 2001 NHTS was GDT Dynamap 2000 (from Census 2000 TIGER/Line files). 


\section{Consolidated Metropolitan Statistical Area (CMSA)}

Destination

Driver

Employed

Education Level

Household
A large metropolitan complex of 1 million or more population, containing two or more identifiable component parts designated as Primary Metropolitan Statistical Areas (PMSAs). For example, the Boston CMSA is composed of six PMSAs.

For travel day trips, the destination is the point at which there is a break in travel, except if the break is only to change vehicles or means of transport. For travel period trips, the destination is the farthest point of travel.

A driver is a person who operates a motorized vehicle. If more than one person drives on a single trip, the person who drives the most miles is classified as the principal driver.

A person is considered employed if ( $\mathrm{s}$ )he worked for pay, either full time or part time, during the week before the interview.

The number of years of regular schooling completed in graded public, private, or parochial schools, or in colleges, universities, or professional schools, whether day school or night school. Regular schooling advances a person toward an elementary or high school diploma, or a college, university, or professional school degree.

A group of persons whose usual place of residence is a specific housing unit; these persons may or may not be related to each other. The total of all U.S. households represents the total civilian non-institutionalized population. A household does not include group quarters (i.e., 10 or more persons living together, none of whom are related). 
Household Income Household income is the money earned by all family members in a household, including those temporarily absent. Annual income consisted of the income earned 12 months preceding the interview. Household income includes monies from all sources, such as wages and salary, commissions, tips, cash bonuses, income from a business or farm, pensions, dividends, interest, unemployment or workmen's compensation, social security, veterans' payments, rent received from owned property (minus the operating costs), public assistance payments, regular gifts of money from friends or relatives not living in the household, alimony, child support, and other kinds of periodic money income other than earnings. Household income excludes in-kind income such as room and board, insurance payments, lump-sum inheritances, occasional gifts of money from persons not living in the same household, withdrawal of savings from banks, tax refunds, and the proceeds of the sale of one's house, car, or other personal property.

Household Members

Household Vehicle
Household members include all people, whether present or temporarily absent, whose usual place of residence is in the sample unit. Household members also include people staying in the sample unit who have no other usual place of residence elsewhere.

A household vehicle is a motorized vehicle that is owned, leased, rented or company-owned and available to be used regularly by household members. Household vehicles include vehicles used solely for business purposes or business-owned vehicles, so long as they are driven home and can be used for the home to work trip, (e.g., taxicabs, police cars, etc.). Household vehicles include all vehicles that were owned or available for use by members of the household during the travel period, even though a vehicle may have been sold before the interview. Vehicles excluded from household vehicles are those that were not working and were not expected to be working, and vehicles that were purchased or received after the designated travel day. 
Means of Transportation
A mode of travel used for going from one place (origin) to another (destination). A means of transportation includes private and public modes, as well as walking.

The following transportation modes, grouped by major mode, are included in the NHTS data.

Private Vehicle

1. Car - A privately owned and/or operated licensed motorized vehicle including cars and station wagons. Leased and rented cars are included if they are privately operated and not used for picking up passengers in return for fare.

2. Van - privately owned and/or operated van or minivan designed to carry 5 to 13 passengers, or to haul cargo.

3. Sport Utility Vehicle - A privately owned and/or operated vehicle that is a hybrid of design elements from a van, a pickup truck and a station wagon. Examples include a Chevrolet Blazer, Ford Bronco, Jeep Cherokee, or Nissan Pathfinder.

4. Pickup Truck - A pickup truck is a motorized vehicle, privately owned and/or operated, with an enclosed cab that usually accommodates 2-3 passengers, and an open cargo area in the rear. Later model pickups often have a back seat that allows for total seating of $4-6$ passengers. Pickup trucks usually have the same size of wheel-base as a full-size station wagon. This category also includes pickups with campers.

5. Other Truck - This category consists of all trucks other than pickup trucks (i.e., dump trucks, trailer trucks, etc.).

6. RV or Motor Home - An RV or motor home includes a self-powered recreational vehicle that is operated as a unit without being towed by another vehicle (e.g., a Winnebago motor home).

7. Motorcycle - This category includes large, medium, and small motorcycles and mopeds.

8. Other POV - A vehicle that cannot be classified into one of the categories above. 
Public Transportation

1. Bus - The bus category includes:

a. city to city buses (buses that run from one urban center to the other),

b. mass transit systems (buses that are available to the general public),

c. school buses, and

d. charter/tour buses (private bus operating on a fixed schedule between population centers).

2. Train - This category includes:

a. Amtrak and intercity train (heavy passenger rail that runs form one urban center to another),

b. Subway and elevated rail (also know as rail rapid transit is a high capacity system operated on a fixed rail or guide way system on a private right of way), and

c. Trolley/streetcars (vehicles that run on a fixed rail system powered by electricity obtained from an overhead power distribution system), and commuter trains and passenger trains.

Other Modes

1. Airplane - Airplanes include commercial airplanes and smaller planes that are available for use by the general public in exchange for a fare. Private and corporate planes and helicopters are also included.

2. Ship - This includes travel by ships, cruise ships, passenger lines and ferries, sailboats, motorboats and yachts.

3. Taxi - Taxis include the use of a taxicab by a passenger for fare. The taxi category does not include rental cars if they are privately operated.

4. Limousine - Includes the use of a limousine by passenger for fare. The limousine category does not include rental cars if they are privately operated.

5. Hotel/Airport Shuttle - This includes privately operated shuttle buses that are operated between a limited number of points for a fare.

6. Bicycle - This category includes bicycles of all speeds and sizes that do not have a motor.

7. Walk. - This category includes walking and jogging. 
Metropolitan Statistical Area (MSA)

\section{Motorized Vehicle}

Occupancy

Origin

Overlap Trip

Passenger

Person Miles of Travel (PMT)
8. Other - Includes any types of transportation not previously listed, e.g. skate boards.

Except in the New England States, a Metropolitan Statistical Area is a county or group of contiguous counties which contains at least one city of 50,000 inhabitants or more, or "twin cities" with a combined population of at least 50,000 . In addition, contiguous counties are included in an MSA if, according to certain criteria, they are socially and economically integrated with the central city. In the New England States, MSA's consist of towns and cities instead of counties. The source used for the 2001 NHTS was 1999 Metropolitan Areas: Cartographic Boundary Files. File ma99_99.shp from http://www.census.gov/geo/www/cob/ma1999.html.

Motorized vehicles are all vehicles that are licensed for highway driving.

Occupancy is the number of persons, including driver and passenger(s) in a vehicle. NHTS occupancy rates are generally calculated as person miles divided by vehicle miles.

Origin is the starting point of a trip.

A travel period trip that occurs on travel day, and is thus collected in both portions of the NHTS questionnaire. To ensure that this trip is not counted twice, eliminate overlap trips from travel day data when travel day and travel period data will be added together.

For a specific trip, a passenger is any occupant of a motorized vehicle, other than the driver.

PMT is a primary measure of person travel. When one person travels one mile, one person mile of travel results. Where 2 or more persons travel together in the same vehicle, each person makes the same number of person miles as the vehicle miles. Therefore, four persons traveling 5 miles in the same vehicle results in 20 person miles $(4 \times 5=20)$. 
Person Trip A person trip is a trip by one or more persons in any mode of transportation. Each person is considered as making one person trip. For example, four persons traveling together in one auto are counted as four person trips.

POV

A privately-owned vehicle or privately-operated vehicle. Either way, the intent here is that this is not a vehicle available to the public for a fee, such as a bus, subway, taxi, etc.

Travel Day

A travel day is a 24-hour period from 4:00 a.m. to 3:59 a.m. designated as the reference period for studying trips and travel by members of a sampled household.

Travel Period A travel period consists of a four-week period ending with the travel day.

Travel Day Trip A travel day trip is defined as any time the respondent went from one address to another by private motor vehicle, public transportation, bicycle, walking, or other means. However, a separate trip is not counted in two instances:

1. When the sole purpose for the trip is to get to another vehicle or mode of transportation in order to continue to the destination.

2. Travel within a shopping center, mall or shopping areas of 4-5 blocks is to be considered as travel to one destination.

Travel Period Trip

A travel period trip is a trip where the farthest destination is at least 50 miles from home. The outgoing portion of this trip can take place at any time, but the return must be within the four-week travel period. The four-week travel period ends on and includes the assigned travel day.

Travel Day Trip Purpose

A trip purpose is the main reason that motivates a trip. There are 36 travel day trip purposes used in the 2001 NHTS. 
For the 2001 Survey, trip purposes were collected using a From-To approach. For each trip, the origin and destination are on the file in generic terms, e.g. from work to shopping. The 36 trip reasons are defined as follows, and shown with their coded trip purpose number.

1. To Home - Travel to home after leaving for some reason.

11. Go to Work - The first trip to the work location on travel day.

12. Return to Work - A trip to work that is not the first trip to work on the travel day.

13. Attend Business Meeting/Trip - A work related trip whose purpose is to attend a business meeting.

14 Other Work Related - A work related trip whose purpose is not specifically to attend a business meeting.

20. Other School/Religious Activity - School and religious activities not covered by categories 21 through 23 below.

21. Go to School as a Student - A trip whose purpose is to go to school as a student.

22. Go to Religious Activity - A trip whose purpose is to go to a place to attend a religious activity.

23. Go to Library, School Related - A trip whose purpose is to go to the library as part of a school related activity.

24. Go to Daycare - A trip whose purpose is to attend day care.

30. Medical/Dental Services - A trip made for medical, dental, or mental health treatment, or other related professional services.

40. Shopping/Errands - Shopping/errand trips not covered by categories 41 through 43 below.

41. Buy Goods, (e.g., groceries/clothing/hardware store) - A shopping trip whose purpose is to purchase commodities for use or consumption elsewhere. This purpose also includes windowshopping and trip made to shop even if nothing is purchased. 
42. Buy Services, (e.g., video rentals/dry cleaning/post office/car service/bank) - The category includes the purchase of services other than medical/dental or other professional services.

43. Buy Gas - A trip made specifically to get gas.

50. Social/Recreational - Includes social and recreational trips not covered by categories 51 through 55 below.

51. Go to the Gym/Exercise/Play Sports - A trip made for exercise or to participate in a sport.

52. Rest or Relaxation/Vacation.

53. Visit Friends/Relatives - The social/recreational trip whose purpose is to visit with family and friends.

54. Go out/Hang out, Entertainment/Theater/Sports Event/Go to Bar The purpose of the trip is entertainment or hanging out with friends.

55. Visit Public Place, Historical Site/Museum/Park/Library.

60. Family Personal Business/Obligations - A trip for personal business not covered by categories 61 through 65 below.

61. Use Professional Services, Attorney/Accountant - A trip made for professional services other than for medical/dental purposes.

62. Attend Funeral/Wedding - A personal trip to attend a funeral or a wedding.

63. Use Personal Services, Grooming/Haircut/Nails - A trip for personal services such as to a hairdresser.

64. Pet Care, Walk the dog/Vet visits.

65. Attend Meeting, PTA/Home Owners Association/Local Government - The purpose of the trip is to attend a non-work related meeting, such as a community meeting.

70. Transport Someone - Trips with a passenger that are related to picking up or dropping off someone but not covered by categories 71 through 73 below.

71. Pickup Someone. 
72. Take and Wait - A trip made to take someone to a destination and then wait with them at the destination and return together.

73. Drop Someone Off.

80. Meals - A trip whose purpose is to eat or get a meal but not covered by categories 81 through 83 below.

81. Social Event - A trip whose purpose is to eat a meal at a social event.

82. Get/Eat Meal - A trip whose purpose is to get and eat a meal but not at a social event.

83. Coffee/Ice Cream/Snacks - A trip whose purpose is to get/eat a snack or drink, something less than a meal.

91. Other - A trip purpose not covered by categories above.

Travel Period Trip Purpose

Urbanized Area
A trip purpose is the main reason that motivates a trip. There were 18 travel period trip purposes in the 2001 NHTS. The main reason and all other reasons for the trip were collected.

An urbanized area consists of the built up area surrounding a central core (or central city), with a population density of at least 1,000 persons per square mile. Urbanized areas do not follow jurisdictional boundaries thus it is common for the urbanized area boundary to divide a county.

For the 2001 NHTS, Urban Areas were calculated two ways.

1. Variable URBAN uses the 2000 Urbanized Areas: Cartographic Boundary Files. File ua00_d00.shp from http://www.census.gov/geo/www/cob/ua2000.html. Two codes are used: $0=$ Not in Urban Area, $1=$ in Urban Area.

2. Variable URBAN1 uses the 2000 Urbanized Areas: Cartographic Boundary Files. File ua00_d00.shp from http://www.census.gov/geo/www/cob/ua2000.html. Three codes are used: $0=$ Not in Urban Area, $1=$ in Urban Cluster, $2=$ in Urban Area, $3=$ in area surrounded by urban areas. 
Vehicle

Vehicle Miles of Travel (VMT)

Vehicle

Occupancy

Vehicle Trip
The 2001 NHTS, the term vehicle includes autos, passenger vans, sport utility vehicles, pickups and other light trucks, RV's, motorcycles and mopeds owned or available to the household.

VMT is a unit to measure vehicle travel made by a private vehicle, such as an automobile, van, pickup truck, or motorcycle. Each mile traveled is counted as one vehicle mile regardless of the number of persons in the vehicle.

Vehicle occupancy is the number of persons, including driver and passenger(s) in a vehicle; also includes persons who did not complete a whole trip. NHTS occupancy rates are generally calculated as person miles divided by vehicle miles.

A trip by a single privately-operated vehicle (POV) regardless of the number of persons in the vehicle. 
Vehicle Type For purposes of the 2001 NHTS, one of the following:

1. Automobile (including station wagon)

2. Van

3. Sport Utility Vehicle

4. Pickup Truck (including pickup with camper)

5. Other Truck

6. RV or Motor Home

7. Motorcycle

8. Other 


\section{APPENDIX 1}

\section{SELECTED TABLES INCLUDING TRAVEL OF INDIVIDUALS 0 to 4 YEAR-OLDS}


This page intentionally left blank.

A1-2 
Table 5

Average Annual PMT, Person Trips and Trip Length by Trip Purpose

1983, 1990, 1995 NPTS, and 2001 NHTS

(2001 NHTS contains 0 to 4 year-olds)

\begin{tabular}{|c|c|c|c|c|c|}
\hline Trip Purpose & 1983 & 1990 & $\begin{array}{c}1990 \\
\text { Adjusted }\end{array}$ & 1995 & 2001 \\
\hline \multicolumn{6}{|c|}{ Average Annual PMT per Household } \\
\hline All Purposes & 22,802 & 24,803 & 30,316 & 34,459 & 37,002 \\
\hline To/From Work & 4,586 & 5,637 & 5,637 & 7,740 & 6,706 \\
\hline Work Related Business & 1,354 & 1,043 & 1,043 & 1,987 & 2,987 \\
\hline Shopping & 2,567 & 2,674 & 3,343 & 4,659 & 5,188 \\
\hline All Other Fam/Per Business & 3,311 & 5,083 & 7,167 & 7,381 & 7,245 \\
\hline School/Church & 1,522 & 1,599 & 1,599 & 1,973 & 2,198 \\
\hline Social and Recreational & 8,964 & 8,567 & 11,308 & 10,571 & 11,281 \\
\hline Other & 500 & 195 & 214 & 131 & 1,262 \\
\hline \multicolumn{6}{|c|}{ Average Annual Person Trips per Household } \\
\hline All Purposes & 2,628 & 2,673 & 3,262 & 3,828 & 3,793 \\
\hline To/From Work & 537 & 539 & 539 & 676 & 565 \\
\hline Work Related Business & 62 & 38 & 38 & 100 & 109 \\
\hline Shopping & 474 & 504 & 630 & 775 & 749 \\
\hline All Other Fam/Per Business & 456 & 606 & 854 & 981 & 938 \\
\hline School/Church & 310 & 304 & 304 & 337 & 373 \\
\hline Social and Recreational & 728 & 662 & 874 & 953 & 1,022 \\
\hline Other & 61 & 20 & 22 & 6 & 32 \\
\hline \multicolumn{6}{|c|}{ Average Person Trip Length (miles) } \\
\hline All Purposes & 8.68 & 9.45 & 9.47 & 9.13 & 9.94 \\
\hline To/From Work & 8.54 & 10.65 & 10.65 & 11.63 & 12.11 \\
\hline Work Related Business & 21.77 & 28.20 & 28.20 & 20.28 & 28.26 \\
\hline Shopping & 5.41 & 5.38 & 5.38 & 6.08 & 7.03 \\
\hline All Other Fam/Per Business & 7.27 & 8.55 & 8.55 & 7.63 & 7.85 \\
\hline School/Church & 4.90 & 5.39 & 5.39 & 5.98 & 6.02 \\
\hline Social and Recreational & 12.31 & 13.19 & 13.19 & 11.27 & 11.27 \\
\hline Other & 8.22 & 10.30 & 10.30 & 22.83 & 41.52 \\
\hline
\end{tabular}

Note:

- Average person trip length for 199, 1995, and 2001 is calculated using only those records with trip mileage information present.

- All tables reporting totals could include some unreported characteristics.

- Note that only the 1990 data have been adjusted to make them more comparable with the 1995 and 2001 data. Thus, there are limits on the conclusions that can be drawn in comparing travel with earlier survey years. The adjustments to 1990 data affect only person trips, vehicle trips, person miles of travel (PMT) and vehicle miles of travel (VMT). 
Table 7

Average Annual Person Trips per Household

by Mode of Transportation and MSA Size

1977, 1983, 1990, 1995 NPTS, and 2001 NHTS

(2001 NHTS contains 0 to 4 year-olds)

\begin{tabular}{|c|c|c|c|c|c|c|}
\hline \multicolumn{7}{|c|}{ Mode of Transportation } \\
\hline SMSA or MSA Size & 1977 & 1983 & 1990 & 1990 Adjusted & 1995 & 2001 \\
\hline \multicolumn{7}{|c|}{ Private } \\
\hline ALL & 2,351 & 2,152 & 2,329 & 2,861 & 3,307 & 3,276 \\
\hline Not in (S)MSA & 2,436 & 2,322 & 2,306 & 2,837 & 3,492 & 3,251 \\
\hline Less than 250,000 & 2,517 & 2,375 & 2,508 & 3,090 & 3,503 & 3,481 \\
\hline 250,000 - 499,999 & 2,574 & 2,443 & 2,461 & 3,014 & 3,472 & 3,425 \\
\hline $500,000-999,999$ & 2,628 & 2,140 & 2,413 & 2,957 & 3,509 & 3,519 \\
\hline $1,000,000-2,999,999$ & 2,366 & 2,031 & 2,430 & 2,986 & 3,354 & 3,362 \\
\hline $3,000,000$ and above & 1,785 & 1,691 & 2,160 & 2,649 & 3,075 & 3,108 \\
\hline \multicolumn{7}{|c|}{ PublicTransit } \\
\hline ALL & 73 & 60 & 52 & 58 & 67 & 60 \\
\hline Not in (S)MSA & 22 & 11 & 13 & 14 & 9 & 6 \\
\hline Less than 250,000 & 47 & 17 & 27 & 30 & 23 & 12 \\
\hline 250,000 - 499,999 & 44 & 23 & 19 & 22 & 18 & 22 \\
\hline $500,000-999,999$ & 58 & 48 & 28 & 33 & 33 & 12 \\
\hline $1,000,000-2,999,999$ & 86 & 67 & 46 & 52 & 37 & 38 \\
\hline $3,000,000$ and above & 189 & 181 & 112 & 124 & 137 & 134 \\
\hline \multicolumn{7}{|c|}{ Walk } \\
\hline ALL & 261 & 226 & 193 & 234 & 205 & 329 \\
\hline Not in (S)MSA & 199 & 211 & 146 & 175 & 134 & 232 \\
\hline Less than 250,000 & 241 & 280 & 172 & 212 & 138 & 262 \\
\hline 250,000 - 499,999 & 206 & 199 & 165 & 203 & 152 & 267 \\
\hline 500,000 - 999,999 & 256 & 184 & 132 & 161 & 138 & 238 \\
\hline $1,000,000-2,999,999$ & 295 & 179 & 170 & 207 & 162 & 292 \\
\hline $3,000,000$ and above & 396 & 330 & 278 & 337 & 301 & 455 \\
\hline \multicolumn{7}{|c|}{ ALL MODES } \\
\hline ALL & 2,808 & 2,628 & 2,673 & 3,262 & 3,828 & 3,793 \\
\hline Not in (S)MSA & 2,800 & 2,766 & 2,580 & 3,151 & 3,878 & 3,624 \\
\hline Less than 250,000 & 2,944 & 2,889 & 2,816 & 3,450 & 3,926 & 3,872 \\
\hline 250,000 - 499,999 & 2,945 & 2,891 & 2,741 & 3,340 & 3,894 & 3,842 \\
\hline 500,000 - 999,999 & 3,049 & 2,542 & 2,667 & 3,252 & 3,916 & 3,881 \\
\hline $1,000,000-2,999,999$ & 2,861 & 2,463 & 2,737 & 3,344 & 3,795 & 3,814 \\
\hline $3,000,000$ and above & 2,459 & 2,326 & 2,641 & 3,213 & 3,765 & 3,830 \\
\hline
\end{tabular}

Note:

- The population size groups for 1977 - 1983 NPTS are SMSA Size Groups and 1990 - 2001 are MSA Size Groups.

- In 2001, the mode "Bus" was divided into "Local Public Transit Bus," "Commuter Bus," "Charter/tour bus," and "City to city bus." Only "Local Public Transit Bus" and "Commuter Bus" are included in public transit calculations.

- All modes includes other modes not specified such as bike, school bus, taxi and other.

- All tables reporting totals could include some unreported characteristics.

- Note that only the 1990 data have been adjusted to make them more comparable with the 1995 and 2001 data. Thus, there are limits on the conclusions that can be drawn in comparing travel with earlier survey years. The adjustments to 1990 data affect only person trips, vehicle trips, person miles of travel (PMT) and vehicle miles of travel (VMT). 
Table 8

Person Trips per Household by Household Income

1983, 1990, and 1995 NPTS and 2001 NHTS

\begin{tabular}{||l|cc||ccc|c||}
\hline Income & 1983 & 1990 & $\begin{array}{c}1990 \\
\text { Adjusted }\end{array}$ & 1995 & 2001 & $\begin{array}{c}\text { Annual } \\
\text { Compounded } \\
\text { Rate, } \\
1990-2001\end{array}$ \\
ALL & 2,628 & 2,673 & 3,262 & 3,828 & 3,793 & $1.4 \%$ \\
$<\$ 10,000$ & 1,407 & 1,710 & 2,098 & 2,137 & 2,196 & $0.4 \%$ \\
$\$ 10$ to $\$ 20,000$ & 1,927 & 1,968 & 2,412 & 2,790 & 2,689 & $1.0 \%$ \\
$\$ 20$ to $\$ 30,000$ & 2,376 & 2,455 & 3,008 & 3,522 & 3,248 & $0.7 \%$ \\
$\$ 30$ to $\$ 40,000$ & 2,739 & 2,802 & 3,431 & 3,980 & 3,730 & $0.8 \%$ \\
$\$ 40$ to $\$ 50,000$ & 3,037 & 3,101 & 3,791 & 4,298 & 4,134 & $0.8 \%$ \\
$\$ 50$ to $\$ 60,000$ & 3,284 & 3,391 & 4,138 & 4,539 & 4,618 & $1.0 \%$ \\
$\$ 60$ to $\$ 70,000$ & 3,485 & 3,660 & 4,458 & 4,726 & 4,828 & $0.7 \%$ \\
$\$ 70$ to $\$ 80,000$ & 3,635 & 3,832 & 4,659 & 4,855 & 5,161 & $0.9 \%$ \\
$\$ 80,000+$ & 3,602 & 3,747 & 4,570 & 4,829 & 5,251 & $1.3 \%$ \\
Unreported & & 2,090 & 2,536 & 3,424 & 2,499 & $-0.1 \%$ \\
\hline
\end{tabular}

Note:

- Incomes for 1983, 1990, adjusted 1990, and 1995 have been adjusted to 2001 dollars.

- All tables reporting totals could include some unreported characteristics.

- Note that only the 1990 person trip data have been adjusted to make them more comparable with the 1995 and 2001 data. Thus, there are limits on the conclusions that can be drawn in comparing travel with earlier survey years. The adjustments to 1990 data affect only person trips, vehicle trips, person miles of travel (PMT) and vehicle miles of travel (VMT). 
Table 9

Total Person Trips by Mode of Transportation and Trip Purpose Adjusted 1990 and 1995 NPTS, and 2001 NHTS (millions)

(2001 NHTS contains 0 to 4 year-olds)

\begin{tabular}{|c|c|c|c|c|c|c|c|}
\hline & Total & $\begin{array}{l}\text { To or } \\
\text { From } \\
\text { Work }\end{array}$ & $\begin{array}{c}\text { Work } \\
\text { Related } \\
\text { Business }\end{array}$ & $\begin{array}{c}\text { Family and } \\
\text { Personal } \\
\text { Business }\end{array}$ & $\begin{array}{c}\text { School } \\
\text { or } \\
\text { Church }\end{array}$ & $\begin{array}{c}\text { Social and } \\
\text { Recreational }\end{array}$ & Other \\
\hline \multicolumn{8}{|c|}{ Private } \\
\hline $1990 \mathrm{Adj}$ & $\begin{array}{l}267,029 \\
(87.7 \%)\end{array}$ & $\begin{array}{c}45,856 \\
(91.1 \%)\end{array}$ & $\begin{array}{c}3,178 \\
(90.1 \%)\end{array}$ & $\begin{array}{l}128,368 \\
(92.6 \%)\end{array}$ & $\begin{array}{c}17,545 \\
(61.8 \%)\end{array}$ & $\begin{array}{c}70,382 \\
(86.3 \%)\end{array}$ & $\begin{array}{c}1,629 \\
(80.9 \%)\end{array}$ \\
\hline 1995 & $\begin{array}{l}327,400 \\
(86.4 \%)\end{array}$ & $\begin{array}{c}60,740 \\
(90.8 \%)\end{array}$ & $\begin{array}{c}8,835 \\
(89.6 \%)\end{array}$ & $\begin{array}{l}156,065 \\
(89.8 \%)\end{array}$ & $\begin{array}{c}22,436 \\
(67.3 \%)\end{array}$ & $\begin{array}{c}78,809 \\
(83.5 \%)\end{array}$ & $\begin{array}{c}470 \\
(75.4 \%)\end{array}$ \\
\hline 2001 & $\begin{array}{l}351,692 \\
(86.4 \%)\end{array}$ & $\begin{array}{c}56,054 \\
(92.4 \%)\end{array}$ & $\begin{array}{c}10,648 \\
(91.2 \%)\end{array}$ & $\begin{array}{l}164,766 \\
(91.0 \%)\end{array}$ & $\begin{array}{c}28,970 \\
(72.4 \%)\end{array}$ & $\begin{array}{c}88,475 \\
(80.6 \%)\end{array}$ & $\begin{array}{c}2,350 \\
(68.4 \%)\end{array}$ \\
\hline \multicolumn{8}{|c|}{ Public Transit } \\
\hline $1990 \mathrm{Adj}$ & $\begin{array}{c}5,460 \\
(1.8 \%)\end{array}$ & $\begin{array}{c}1,992 \\
(4.0 \%)\end{array}$ & $\begin{array}{c}92 \\
(2.6 \%)\end{array}$ & $\begin{array}{c}1,318 \\
(1.0 \%)\end{array}$ & $\begin{array}{c}1,076 \\
(3.8 \%)\end{array}$ & $\begin{array}{c}946 \\
(1.2 \%)\end{array}$ & $\begin{array}{c}35 \\
(1.7 \%)\end{array}$ \\
\hline 1995 & $\begin{array}{c}6,638 \\
(1.8 \%)\end{array}$ & $\begin{array}{c}2,328 \\
(3.5 \%)\end{array}$ & $\begin{array}{c}123 \\
(1.2 \%)\end{array}$ & $\begin{array}{c}2,000 \\
(1.2 \%)\end{array}$ & $\begin{array}{c}826 \\
(2.5 \%)\end{array}$ & $\begin{array}{c}1,350 \\
(1.4 \%)\end{array}$ & $\begin{array}{c}11 \\
(1.8 \%)\end{array}$ \\
\hline 2001 & $\begin{array}{c}6,475 \\
(1.6 \%)\end{array}$ & $\begin{array}{c}2,271 \\
(3.7 \%)\end{array}$ & $\begin{array}{c}213 \\
(1.8 \%)\end{array}$ & $\begin{array}{c}1,954 \\
(1.1 \%)\end{array}$ & $\begin{array}{c}825 \\
(2.1 \%)\end{array}$ & $\begin{array}{c}1,057 \\
(1.0 \%)\end{array}$ & $\begin{array}{c}134 \\
(3.9 \%)\end{array}$ \\
\hline \multicolumn{8}{|c|}{ Walk } \\
\hline $1990 \mathrm{Adj}$ & $\begin{array}{l}21,879 \\
(7.2 \%)\end{array}$ & $\begin{array}{c}1,999 \\
(4.0 \%)\end{array}$ & $\begin{array}{c}154 \\
(4.4 \%)\end{array}$ & $\begin{array}{c}7,722 \\
(5.6 \%)\end{array}$ & $\begin{array}{c}3,649 \\
(12.8 \%)\end{array}$ & $\begin{array}{c}8,090 \\
(9.9 \%)\end{array}$ & $\begin{array}{c}265 \\
(13.2 \%)\end{array}$ \\
\hline 1995 & $\begin{array}{l}20,325 \\
(5.4 \%)\end{array}$ & $\begin{array}{c}1,510 \\
(2.3 \%)\end{array}$ & $\begin{array}{c}240 \\
(2.4 \%)\end{array}$ & $\begin{array}{c}8,756 \\
(5.0 \%)\end{array}$ & $\begin{array}{c}2,925 \\
(8.8 \%)\end{array}$ & $\begin{array}{c}6,845 \\
(7.3 \%)\end{array}$ & $\begin{array}{c}47 \\
(7.6 \%)\end{array}$ \\
\hline 2001 & $\begin{array}{l}35,366 \\
(8.7 \%)\end{array}$ & $\begin{array}{c}1,715 \\
(2.8 \%)\end{array}$ & $\begin{array}{c}487 \\
(4.2 \%)\end{array}$ & $\begin{array}{l}12,744 \\
(7.0 \%)\end{array}$ & $\begin{array}{c}3,737 \\
(9.3 \%)\end{array}$ & $\begin{array}{c}16,108 \\
(14.7 \%)\end{array}$ & $\begin{array}{c}527 \\
(15.3 \%)\end{array}$ \\
\hline \multicolumn{8}{|c|}{ Other } \\
\hline $1990 \mathrm{Adj}$ & $\begin{array}{c}9,867 \\
(3.2 \%)\end{array}$ & $\begin{array}{c}428 \\
(0.8 \%)\end{array}$ & $\begin{array}{c}95 \\
(2.7 \%)\end{array}$ & $\begin{array}{c}1,087 \\
(0.8 \%)\end{array}$ & $\begin{array}{c}6,086 \\
(21.4 \%)\end{array}$ & $\begin{array}{c}2,098 \\
(2.6 \%)\end{array}$ & $\begin{array}{c}73 \\
(3.6 \%)\end{array}$ \\
\hline 1995 & $\begin{array}{l}12,099 \\
(3.2 \%)\end{array}$ & $\begin{array}{c}887 \\
(1.3 \%)\end{array}$ & $\begin{array}{c}417 \\
(4.2 \%)\end{array}$ & $\begin{array}{c}1,768 \\
(1.0 \%)\end{array}$ & $\begin{array}{c}6,035 \\
(18.1 \%)\end{array}$ & $\begin{array}{c}2,954 \\
(3.1 \%)\end{array}$ & $\begin{array}{c}37 \\
(6.0 \%)\end{array}$ \\
\hline 2001 & $\begin{array}{l}13,345 \\
(3.3 \%)\end{array}$ & $\begin{array}{c}584 \\
(1.0 \%)\end{array}$ & $\begin{array}{c}317 \\
(2.7 \%)\end{array}$ & $\begin{array}{c}1,540 \\
(0.9 \%)\end{array}$ & $\begin{array}{c}6,463 \\
(16.1 \%)\end{array}$ & $\begin{array}{c}4,000 \\
(3.6 \%)\end{array}$ & $\begin{array}{c}408 \\
(11.9 \%)\end{array}$ \\
\hline \multicolumn{8}{|c|}{ TOTAL } \\
\hline $1990 \mathrm{Adj}$ & $\begin{array}{c}304,471 \\
(100 \%)\end{array}$ & $\begin{array}{l}50,314 \\
(100 \%)\end{array}$ & $\begin{array}{c}3,529 \\
(100 \%)\end{array}$ & $\begin{array}{c}138,559 \\
(100 \%)\end{array}$ & $\begin{array}{l}28,397 \\
(100 \%)\end{array}$ & $\begin{array}{l}81,575 \\
(100 \%)\end{array}$ & $\begin{array}{c}2,014 \\
(100 \%)\end{array}$ \\
\hline 1995 & $\begin{array}{c}378,930 \\
(100 \%)\end{array}$ & $\begin{array}{c}66,901 \\
(100 \%)\end{array}$ & $\begin{array}{c}9,860 \\
(100 \%)\end{array}$ & $\begin{array}{c}173,764 \\
(100 \%)\end{array}$ & $\begin{array}{l}33,355 \\
(100 \%)\end{array}$ & $\begin{array}{l}94,362 \\
(100 \%)\end{array}$ & $\begin{array}{c}623 \\
(100 \%)\end{array}$ \\
\hline 2001 & $\begin{array}{c}407,262 \\
(100 \%) \\
\end{array}$ & $\begin{array}{l}60,690 \\
(100 \%) \\
\end{array}$ & $\begin{array}{c}11,676 \\
(100 \%)\end{array}$ & $\begin{array}{l}181,119 \\
(100 \%)\end{array}$ & $\begin{array}{l}40,026 \\
(100 \%)\end{array}$ & $\begin{array}{c}109,732 \\
(100 \%)\end{array}$ & $\begin{array}{c}3,434 \\
(100 \%) \\
\end{array}$ \\
\hline
\end{tabular}

Note:

- All tables reporting totals could include some unreported characteristics. 
- In 2001, the mode "Bus" was divided into "Local Public Transit Bus," "Commuter Bus," "Charter/tour bus," and "City to city bus." Only "Local Public Transit Bus" and "Commuter Bus" are included in public transit calculations.

- Note that only the 1990 data have been adjusted to make them more comparable with the 1995 and 2001 data. Thus, there are limits on the conclusions that can be drawn in comparing travel with earlier survey years. The adjustments to 1990 data affect only person trips, vehicle trips, person miles of travel (PMT) and vehicle miles of travel (VMT). 
Table 28

Distribution of Person Trips by Start Time of Trip

1983, 1990, 1995 NPTS, and 2001 NHTS

(2001 NHTS contains 0 to 4 year-olds)

\begin{tabular}{||l|cc||ccc||}
\hline \multicolumn{1}{|c|}{ Time of Day } & 1983 & 1990 & 1990 & 1995 & 2001 \\
$10 \mathrm{pm}-1 \mathrm{am}$ & 4.0 & 4.0 & 4.1 & 3.5 & 2.8 \\
$1-6 \mathrm{am}$ & 3.3 & 1.9 & 1.8 & 1.7 & 1.8 \\
$6-9 \mathrm{am}$ & 14.4 & 13.9 & 12.5 & 13.8 & 14.2 \\
$9 \mathrm{am} \mathrm{-} \mathrm{1} \mathrm{pm}$ & 23.4 & 20.1 & 20.6 & 24.2 & 24.8 \\
$1-4 \mathrm{pm}$ & 20.8 & 20.4 & 20.7 & 22.1 & 22.2 \\
$4-7 \mathrm{pm}$ & 21.2 & 22.8 & 22.9 & 23.0 & 22.4 \\
$7-10 \mathrm{pm}$ & 12.3 & 12.8 & 13.2 & 11.8 & 11.7 \\
ALL & $\mathbf{1 0 0 . 0}$ & $\mathbf{1 0 0 . 0}$ & $\mathbf{1 0 0 . 0}$ & $\mathbf{1 0 0 . 0}$ & $\mathbf{1 0 0 . 0}$ \\
\hline
\end{tabular}

- Note:

- All tables reporting totals could include some unreported characteristics.

- Note that only the 1990 data have been adjusted to make them more comparable with the 1995 and 2001 data. Thus, there are limits on the conclusions that can be drawn in comparing travel with earlier survey years. The adjustments to 1990 data affect only person trips, vehicle trips, person miles of travel (PMT) and vehicle miles of travel (VMT). 


\section{APPENDIX 2}

\section{KEY CHANGES IN THE 2001 NHTS SURVEY METHODOLOGY AND CONTENT}


This page intentionally left blank. 
APPENDIX 2

KEY CHANGES IN THE 2001 NHTS SURVEY METHODOLOGY AND CONTENT

(Source: Exhibit 3-1, 2001 NHTS User's Guide)

\begin{tabular}{|l|l|l|l|}
\hline \multicolumn{1}{|c|}{ TOPIC } & \multicolumn{1}{|c|}{ FROM } & \multicolumn{1}{c|}{ TO } & \multicolumn{1}{c|}{ PROBABLE IMPACTS } \\
\hline $\begin{array}{l}\text { What is } \\
\text { collected? }\end{array}$ & $\begin{array}{l}\text { Two separate } \\
\text { surveys - the NPTS } \\
\text { and the ATS }\end{array}$ & $\begin{array}{l}\text { Combined survey } \\
\text { that collects both } \\
\text { travel day and travel } \\
\text { period information }\end{array}$ & $\begin{array}{l}\text { Enables analysis of } \\
\text { relationship between daily } \\
\text { and long-distance travel } \\
\text { characteristics of each person }\end{array}$ \\
\hline $\begin{array}{l}\text { Which } \\
\text { household } \\
\text { members are } \\
\text { eligible? }\end{array}$ & $\begin{array}{l}\text { Household members } \\
\text { and older }\end{array}$ & $\begin{array}{l}\text { All household } \\
\text { members }\end{array}$ & More complete trip reporting \\
\hline $\begin{array}{l}\text { When proxy } \\
\text { needed? }\end{array}$ & $\begin{array}{l}\text { Proxy for household } \\
\text { members 5 to 13 } \\
\text { years }\end{array}$ & $\begin{array}{l}\text { Proxy for household } \\
\text { members under 16 } \\
\text { years }\end{array}$ & $\begin{array}{l}\text { - Increase in number of } \\
\text { interviews by proxy } \\
\text { Obtain parental approval } \\
\text { when speaking with } 14 \text { and } \\
15 \text { year olds }\end{array}$ \\
\hline $\begin{array}{l}\text { Respondent } \\
\text { Contact }\end{array}$ & Advance letter & $\begin{array}{l}\text { Advance letter with a } \\
\text { \$5 cash incentive and } \\
\text { a brochure }\end{array}$ & $\begin{array}{l}\text { Improved response } \\
\text { Legitimizes the survey } \\
\text { with respondents }\end{array}$ \\
\hline $\begin{array}{l}\text { Use of a } \\
\text { diary for }\end{array}$ & $\begin{array}{l}\text { The ATS used a } \\
\text { diary to record long- } \\
\text { distance trips }\end{array}$ & $\begin{array}{l}\text { No travel period } \\
\text { diary included }\end{array}$ & $\begin{array}{l}\text { Lower respondent burden and } \\
\text { reduce the possibility of } \\
\text { confusion due to the mailing } \\
\text { of both a travel day and } \\
\text { travel period diary }\end{array}$ \\
\hline
\end{tabular}




\begin{tabular}{|c|c|c|c|}
\hline TOPIC & FROM & TO & PROBABLE IMPACTS \\
\hline $\begin{array}{l}\text { Travel day } \\
\text { trip } \\
\text { definition }\end{array}$ & $\begin{array}{l}\text { Any stop from one } \\
\text { address to the next is } \\
\text { a separate trip }\end{array}$ & $\begin{array}{l}\text { Basically the same - } \\
\text { stops only to change } \\
\text { a mode of } \\
\text { transportation } \\
\text { excluded }\end{array}$ & $\begin{array}{l}\text { May improve reporting of } \\
\text { trips by public } \\
\text { transportation as subjects } \\
\text { were specifically reminded } \\
\text { about these trips } \\
\text { No change mode trips } \\
\text { were recorded except } \\
\text { where public } \\
\text { transportation was } \\
\text { involved }\end{array}$ \\
\hline $\begin{array}{l}\text { Walk and } \\
\text { bike trips on } \\
\text { travel day }\end{array}$ & $\begin{array}{l}\text { No specific mention } \\
\text { of walk and bike } \\
\text { trips }\end{array}$ & $\begin{array}{l}\text { Specific reminder to } \\
\text { include walk, bike } \\
\text { rides and trips that } \\
\text { started and ended in } \\
\text { the same place }\end{array}$ & $\begin{array}{l}\text { Will increase the reporting of } \\
\text { walk and bike trips }\end{array}$ \\
\hline $\begin{array}{l}\text { Travel day } \\
\text { trip purpose }\end{array}$ & $\begin{array}{l}\text { There were } 17 \text { trip } \\
\text { purpose categories }\end{array}$ & $\begin{array}{l}\text { There are } 36 \text { trip } \\
\text { purpose categories }\end{array}$ & $\begin{array}{l}\text { The new categories more } \\
\text { accurately capture responses }\end{array}$ \\
\hline $\begin{array}{l}\text { Most recent } \\
\text { long distance } \\
\text { trip }\end{array}$ & Not collected & Collected & $\begin{array}{l}\text { Facilitate the imputation of } \\
\text { trips for persons with no } \\
\text { reported long distance trips in } \\
\text { travel period }\end{array}$ \\
\hline $\begin{array}{l}\text { Odometer } \\
\text { readings }\end{array}$ & $\begin{array}{l}\text { Readings collected } \\
\text { by contacting the } \\
\text { respondent by phone } \\
\text { or by mail }\end{array}$ & $\begin{array}{l}\text { Data collection } \\
\text { modes also included } \\
\text { the Internet, fax, and } \\
\text { a toll-free } 800 \\
\text { number }\end{array}$ & Improved response \\
\hline Geo-coding & $\begin{array}{l}\text { Limited use of } \\
\text { manual geo-coding }\end{array}$ & $\begin{array}{l}\text { Extensive use of } \\
\text { manual geo-coding }\end{array}$ & $\begin{array}{l}\text { Higher geo-coding success } \\
\text { rates and more accurate geo- } \\
\text { coding }\end{array}$ \\
\hline
\end{tabular}




\begin{tabular}{|c|c|c|c|}
\hline TOPIC & FROM & TO & PROBABLE IMPACTS \\
\hline $\begin{array}{l}\text { Travel } \\
\text { period } \\
\text { length and } \\
\text { travel period } \\
\text { trip } \\
\text { definition }\end{array}$ & $\begin{array}{l}\text { The NPTS included } \\
\text { trips of } 75 \text { miles or } \\
\text { more and used a 2- } \\
\text { week recall period. } \\
\text { The ATS included } \\
\text { trips of } 100 \text { miles or } \\
\text { more taken over a } \\
\text { full year (4 } \\
\text { interviews). }\end{array}$ & $\begin{array}{l}\text { The travel period was } \\
\text { a four-week period. } \\
\text { Trips of } 50 \text { miles or } \\
\text { more from home } \\
\text { were defined as long } \\
\text { distance. }\end{array}$ & $\begin{array}{l}\text { Four-week travel period and } \\
\text { shorter criterion distance } \\
\text { provides information on a } \\
\text { larger sample of long- } \\
\text { distance trips than NPTS and } \\
\text { better recall of trips than } \\
\text { ATS (if not recorded in ATS } \\
\text { diary), but a smaller sample } \\
\text { of trips and greater difficulty } \\
\text { estimating annual long- } \\
\text { distance trip rates than ATS. } \\
\text { The 4-week travel period } \\
\text { may have increased the } \\
\text { potential for telescoping (i.e., } \\
\text { bringing trips into the travel } \\
\text { period). }\end{array}$ \\
\hline $\begin{array}{l}\text { Splitting } \\
\text { walk and } \\
\text { bike trips at } \\
\text { the end of } \\
\text { travel day }\end{array}$ & Not conducted & Conducted & $\begin{array}{l}\text { Walk and bike trip rates may } \\
\text { be higher than on past NPTSs }\end{array}$ \\
\hline $\begin{array}{l}\text { Adding trips } \\
\text { not reported } \\
\text { by household } \\
\text { members } \\
\text { interviewed } \\
\text { earlier }\end{array}$ & Not conducted & Conducted & More complete trip reporting \\
\hline
\end{tabular}




\begin{tabular}{|c|l|l|l|}
\hline TOPIC & \multicolumn{1}{|c|}{ FROM } & \multicolumn{1}{c|}{ TO } & \multicolumn{1}{c|}{ PROBABLE IMPACTS } \\
\hline Weighting & $\begin{array}{l}\text { Raking to control }_{\text {totals }^{1}} \\
\end{array}$ & $\begin{array}{l}\text { Several stages of } \\
\text { separate nonresponse } \\
\text { adjustment and } \\
\text { trimming as well as } \\
\text { raking. }\end{array}$ & Presently unknown. \\
& $\begin{array}{l}\text { An evaluation is to be } \\
\text { conducted. } \\
\text { Changes to cells used } \\
\text { for raking. }\end{array}$ & \\
\hline
\end{tabular}

1 In raking, one adjusts estimates to agree to one set of controls (e. g., ethnicity), then adjusts estimates to a second set of controls (e. g., region), etc. This process is then repeated until all estimates are simultaneously close to the full set of controls. 


\section{APPENDIX 3}

\section{ADJUSTMENT OF 1990 TRAVEL DATA}

A3-1 
This page intentionally left blank.

A3-2 


\section{APPENDIX 3}

\section{ADJUSTMENT OF 1990 TRAVEL DATA}

The 1995 Nationwide Personal Transportation Survey (NPTS) was a significant improvement over previous surveys in the NPTS series. Different methods were used to ensure that more complete trip reporting was obtained. Specifically,

- a travel diary was used by respondents in the 1995 survey, in lieu of memory recalling; and

- "household rostering" was used to capture some trips that may otherwise have been overlooked.

Although these improvements enhance the completeness and accuracy of trip reporting, they prevent any direct comparisons between the 1990 and 1995 travel data. Any travel changes observed between the 1990 and 1995 surveys now reflect not only actual changes in travel during the period but also artifacts of differences in survey methodology. That is, any changes observed between the 1990 and 1995 travel data are presumably attributable to: (1) actual changes in travel behavior, (2) use of travel diaries, (3) use of household rostering, and (4) other improvements in the 1995 survey method such as a better coding scheme to decipher trip purposes. The latter is expected to have a smaller effect than the first three factors. Since no data are available to quantify the impact of these "other" improvements, their impacts are not evaluated in this exercise.

However, the improved coding scheme in 1995 had an effect on trip recording. In 1990, 1.9 billion trips were coded as "other" trip purpose. In 1995, this number was 700 million, a decline of 64\%. These "other" trips are those that can not be classified into any of the existing trip purpose categories. Two reasons contribute to this substantial decrease in "other" trips. First, the information was collected in the 1995 survey on "from" where the trip was originated and "to" 
where the trip was destined. This type of "to" and "from" information enabled the trip purposes to be determined more accurately. As a result, the number of trips with unspecified trip purposes decreased. Second, better schemes to code trip purposes were used both during and after the data collection phase, significantly reducing the ambiguity in trip purposes.

The reduction in trips with unspecified trip purposes presumably increases the number of trips categorized into the proper trip purpose categories. Ideally, one should remove all artifacts that result from an improved method. However, data to address the effects of each of the individual improvements are extremely limited. Our approach was developed to remove as many artifacts that the data allow. Specifically, our approach quantified and removed the effect of the travel diary and household trip rostering on the amount and type of trips in the 1995 NPTS.

\section{Adjustment Approach}

To more accurately reflect travel trends, the 1990 travel data were adjusted to account for two major changes in survey methodology: (1) travel diary, and (2) household rostering. In essence, the 1990 travel data were adjusted in such a way as if a travel diary and household rostering were used in the 1990 survey. The theory is that more trips would have been recorded in the 1990 survey if travel diaries were used. This theory is supported by data collected in the 1995 NPTS pre-test. Data from the 1995 NPTS pre-test showed that travel diaries led to more complete reporting, particularly for incidental trips, such as stopping at a convenience store, which are often forgotten and, therefore, difficult to capture in a household travel survey. Household rostering is also expected to capture more complete trip reporting by helping remind respondents of forgotten trips. Since data from the 1995 NPTS pre-test suggest that the impact of travel diary varies for different trip purposes, separate adjustment factors were developed for different purposes.

Although more detailed trip purpose information was collected in the 1995 survey, for this analysis trip purposes were grouped into four broad categories: (1) work and school, (2) shopping, 
(3) family and personal business other than shopping, and (4) social and recreational. Separating shopping trips from trips taken for other family and personal businesses is based on the belief that travel diaries and household rostering influence reporting on these trips differently. This appendix describes the approach used to quantify impacts of travel diary and household rostering on the number of person trips recorded by these purposes.

Rather than adjust travel data in all previous surveys (e.g., 1969, 1983 NPTS), only 1990 travel data were adjusted. Both original and adjusted 1990 statistics are presented in this report. The user is warned not to compare 1995 results to those from previous NPTS. For trend analysis, the 1995 results should only be compared to the adjusted 1990 statistics.

\section{Impact of Travel Diary on Trip Reporting}

A methodological experiment was designed as part of the 1995 NPTS pre-test to test three different survey methods: memory recall $(n=875)$, memory jogger $(n=729)$, and travel diary $(\mathrm{n}=708)$. Although the pre-test sample sizes are not particularly large, these pretest data provide the only platform to quantify the impact of travel diaries on trip reporting. On an individual basis, using a travel diary indeed captures more trips than recalling the day's trips from the memory (Table A3.1). It was found that the diary method averaged 0.5 trips more per person per day than the recall, or retrospective method [1]. In addition, travel diary use has greater impact on reporting non-work or non-school related trips than on work or school trips. Its impact is the greatest for non-shopping types of family and personal travel, such as visiting a doctor's office, dropping off or picking up someone: $37 \%$ more such trips were reported by using travel diaries than by recalling from memory. 
Table A3.1. Annual Person Trips per Person by Survey Methods

Based on 1995 NPTS Pre-test Data

\begin{tabular}{|l|c|c|c|}
\hline & $\begin{array}{c}\text { Travel Diary } \\
(1)\end{array}$ & $\begin{array}{c}\text { Recall } \\
(2)\end{array}$ & $\%$ Different =[(1)-(2)]/(2) \\
\hline Work and school & 312.50 & 341.64 & $-8.5 \%$ \\
\hline Shopping & 273.09 & 226.20 & $20.7 \%$ \\
\hline Other family and personal & 317.47 & 231.36 & $37.2 \%$ \\
\hline Social and recreational & 293.82 & 244.39 & $20.2 \%$ \\
\hline Other & 8.29 & 7.58 & $9.4 \%$ \\
\hline ALL & $1,205.17$ & $1,051.17$ & $14.7 \%$ \\
\hline
\end{tabular}

The ratio of travel rates between those collected by travel diaries and those by recall approximates the additional trips that would have been reported if travel diaries were used in the 1990 survey. Contrary to our assumption that travel diaries will not increase the number of work and school trips reported, there were fewer work and school trips reported in the 1995 NPTS pretest when travel diaries were used rather than recall. For trip purposes other than work and school, travel diaries capture more trips than recall (Table A3.1). Since travel diaries are not believed to improve the reporting of non-incidental trips such as commute or school trips and since there is no other evidence supporting a decrease in commute or school trips from 1990 to 1995, the impact of travel diaries on reporting these trips is considered null, and no adjustment was made to the 1990 data.

\section{Impact of Household Rostering on Trip Reports}

In "household rostering," the interviewer has the benefit of trip data from all household members who had already been interviewed. For example, suppose person \#1 took a trip and reported that persons \#2 and \#3 were on the trip with him. When persons \#2 and \#3 were interviewed, they were asked to confirm that they were on the trip with person \#1. If they were, 
the trip characteristics were "copied" from person \#1's record to those of person \#2 and person \#3. If person \#2 or person \#3 indicated that they were not on the trip with person \#1, this response was accepted. One benefit of household rostering is that it aids the memory of the respondent and improves trip reporting.

If household rostering had been used in the 1990 NPTS, how many more trips would have been reported? Unfortunately, this question can not be answered directly due to the lack of data. Instead, an indirect approach was developed. The basic idea behind this approach is simple: It is assumed that household rostering does not increase trip reporting from 1990 to 1995 for trips where only one household member is on the trip. Therefore, the travel trends observed between 1990 and 1995 in the "non-accompany" trips are basically due to (1) changes in travel behavior, (2) use of travel diaries, and (3) other improvements in the 1995 survey method (these effects being relatively inconsequential). It should be emphasized that the "non-accompany" trips are not necessarily all single-occupant trips. Rather, they are trips where only one household member is on the trip, with or without being accompanied by non-household members. These trips are referred hereafter as "non-accompany trips."

After adjusting these "non-accompany" trips in 1990 for the impact of travel diaries, the remaining difference between the 1990 and 1995 "non-accompany" trip rates is presumably attributable to the change in travel during the period. Now, adjusting all of the 1990 trips to reflect the impact of trip diary and the change in travel during the five year period, the remaining difference between the 1995 survey data and the adjusted 1990 data presumably reflects the impact of household rostering.

Table A3.2 illustrates the steps taken to estimate the real changes in trip rates observed in the "non-accompany" trips from 1990 to 1995 . The total numbers of "non-accompany" trips reported in the 1990 NPTS are in Column 1. The impact of using travel diaries on reporting trips 
are listed in Column 2. Adjusting 1990 data for diary impact, Column 3 reports the estimated number of trips by purpose that would have been collected in 1990 had travel diaries been used. Comparing the adjusted 1990 figures (Column 3) to comparable 1995 data (Column 4), one can calculate the percentage change in travel from 1990 to 1995 by trip purpose. The overall increase is nearly $30 \%$, approximately $4.5 \%$ per year for the five year period.

Table A3.2. Estimated Travel Changes from 1990 to 1995

Based on trips without other household members "accompanied"

\begin{tabular}{||l|c|c|c|c|c||}
\hline \multirow{1}{*}{ Purpose } & $(1)$ & $(2)$ & $(3)=(1) \times[(=1+(2)]$ & $(4)$ & $\begin{array}{c}(5)= \\
{[(4)-(3)] /(3)}\end{array}$ \\
\cline { 2 - 6 } & $\begin{array}{c}19901-\mathrm{hhm}^{1} \text { trips } \\
(000)\end{array}$ & $\begin{array}{c}\text { Diary } \\
\text { Impact }^{2} \\
(\%)\end{array}$ & $\begin{array}{c}19901-\mathrm{hhm} \text { trips } \\
\text { adjusted for } \\
\text { diary impact }\end{array}$ & $\begin{array}{c}19951-\mathrm{hhm} \text { trips } \\
(000)\end{array}$ & $\begin{array}{c}\text { change } \\
\text { in travel } \\
(\%)\end{array}$ \\
\hline Work, School & $62,973,929$ & 0 & $62,973,929$ & $84,974,961$ & 34.9 \\
\hline Shopping & $27,983,544$ & 20.7 & $33,860,088$ & $45,996,625$ & 35.8 \\
\hline Other Fam/Per & $33,237,593$ & 37.2 & $45,535,502$ & $58,602,172$ & 28.7 \\
\hline Soc/Rec & $33,166,604$ & 20.2 & $39,799,925$ & $46,509,286$ & 16.9 \\
\hline Other & $1,233,007$ & 9.4 & $1,343,978$ & 356,444 & -73.5 \\
\hline TOTAL & $158,594,677$ & \multicolumn{5}{|l|}{} \\
\hline
\end{tabular}

${ }^{1} 1$-household-member $(1-\mathrm{hhm})$ trips $=$ Trips where no other household members "accompanied."

${ }^{2}$ From Table 1.

This approach suggests that Americans as a whole took approximately 35 percent more commute and school trips from 1990 to 1995. A number of factors could contribute to this increase in the total number of work and school trips. For example, the number of workers increased by $11 \%$ during this period. Note that the number of "other" trips decreased by $74 \%$ due to a better trip purpose coding scheme. The lack of appropriate and sufficient data prohibits an evaluation of the impact of this improved coding scheme. Thus, no adjustments are made to 1990 trips categorized as "other" trip purpose. These trips are a very small proportion of all trips. 
With these calculations, the revised estimates of 1990 trips now reflect adjustments for (1) trip diary and (2) change in travel. Presumably, the remaining difference between the 1995 survey data and the adjusted 1990 data reflects the impact of household rostering. Table A3.3 demonstrates the steps to estimate this effect. First, the number of trips collected in the 1990 survey was adjusted for the diary impact (e.g., 21\% for shopping trips) and for the change in travel between 1990 and 1995 (e.g., 36\% for shopping trips). It can be reasonably assumed that after this adjustment the 1990 data are almost comparable to the 1995 data except for the impact of household rostering. The percentage difference between this adjusted 1990 data and the observed 1995 data is used to estimate the impact of household rostering (Table A3.3). Based on this somewhat convoluted approach, we estimated that approximately $4 \%$ more shopping trips would have been reported in the 1990 survey if household rostering had been used. Again, the number of "other" trips decreased by $74 \%$ due to a better trip purpose coding scheme. The lack of appropriate and sufficient data prohibits an evaluation of the impact of this improved coding scheme. Thus, no adjustment is done to 1990 trips categorized with the "other" trip purpose.

Table A3.3. Estimated Impacts of Household Rostering by Trip Purpose

\begin{tabular}{||l|c|c|c|c|c|c||}
\hline \multirow{3}{*}{ Purpose } & $(1)$ & $(2)$ & $(3)$ & $\begin{array}{c}(4)= \\
(1) \times[(2)+(3)] / 100\end{array}$ & $\begin{array}{c}(6)= \\
{[(5)-(4)] /(4)}\end{array}$ \\
\cline { 2 - 7 } & $\begin{array}{c}1990 \\
(000)\end{array}$ & $\begin{array}{c}\text { Diary } \\
\text { Impact } \\
(\%)\end{array}$ & $\begin{array}{c}\text { change } \\
\text { in travel } \\
(\%)\end{array}$ & $\begin{array}{c}1990 \text { trips adjusted } \\
\text { for diary impact } \\
\text { and \% change in } \\
\text { travel }\end{array}$ & $\begin{array}{c}1995 \\
\text { Total Trips } \\
(000)\end{array}$ & $\begin{array}{c}\text { impact of } \\
\text { trip rostering } \\
(\%)\end{array}$ \\
\hline Work, School & $82,240,011$ & 0 & 34.9 & $110,941,885$ & $110,115,282$ & -0.7 \\
\hline Shopping & $47,056,740$ & 20.7 & 35.8 & $73,643,798$ & $76,688,225$ & 4.1 \\
\hline Other Fam/Per & $56,551,552$ & 37.2 & 28.7 & $93,819,025$ & $97,075,588$ & 3.5 \\
\hline Soc/Rec & $61,799,215$ & 20.2 & 16.9 & $84,726,724$ & $94,361,999$ & 11.4 \\
\hline Other & $1,914,779$ & 9.4 & -73.5 & 687,406 & 689,270 & 0.3 \\
\hline \hline
\end{tabular}

Adjustment Factors for 1990 Travel Data

By combining the impact of travel diary (Column 2 of Table A3.3) and the impact of 
household rostering (Column 6 of Table A3.3), the factors used to adjust 1990 travel data range from no adjustment for work and school trips to a $41 \%$ increase for trips taken for other family and personal business (i.e., non-shopping trips) (Table A3.4). These adjustment factors suggest that between 1990 and 1995 the total number of person trips increased about 4.5\% per year, compared to a rate of $2.6 \%$ between 1969 and 1990. However, after taken into account the population increases over the years, these adjustment factors suggest that a typical American increased his/her trips by $2.7 \%$ per year (Table A3.5). This rate is comparable to the $2 \%$ increase observed between the 1969 and 1990 surveys.

The fundamental assumption in this approach is that the changes observed in the "nonaccompany" trips reflect the changes observed in all trips. The validity of this assumption is checked by first examining how representative the "non-accompany" trips are in both 1990 and 1995. "Non-accompany" trips in both 1990 and 1995 account for no less than 50 percent of the total person trips (Table A3.6), suggesting that using "non-accompany" trips to estimate the magnitude of travel changes in all trips appears to be reasonable. The validity of this assumption is further verified by checking whether the "non-accompany" rate has changed from 1990 to 1995. More than three quarters of work trips and school trips are not accompanied by other household members. This percentage remains relatively stable from 1990 to 1995 (Table A3.6). Note that dropping off and picking up children from schools are not considered "school trips" they are categorized under "Other family and personal business." Almost all trips remain somewhat stable for the non-accompany rate between 1990 and 1995 except social and recreational trips. There is a smaller percentage of social and recreational trips in 1995 that went "unaccompanied by other households" than in 1990: $49 \%$ vs. 54\%. That data seem to support the idea that using only "nonaccompany" trips to estimate travel changes between 1990 and 1995 is reasonable. 
Table A3.4. 1990 Travel Data Adjustment (Person trips in thousands)

\begin{tabular}{||l|c|c|c|c|c||}
\hline Purpose & $\begin{array}{c}1990 \text { Trips } \\
(1)\end{array}$ & $\begin{array}{c}\text { Adjustment } \\
\text { Factor } \\
(2)\end{array}$ & $\begin{array}{c}\text { Adjusted } \\
1990 \text { Trips } \\
(1) \times(2)\end{array}$ & 1995 Trips & $\begin{array}{c}\text { Average } \\
\text { Annual \% } \\
\text { Change }\end{array}$ \\
\hline Work, School & $82,240,011$ & 1.00 & $82,240,011$ & $110,115,282$ & 6.01 \\
\hline Shopping & $47,056,740$ & 1.25 & $58,820,925$ & $76,688,225$ & 5.45 \\
\hline Other Fam/Per Bus & $56,551,552$ & 1.41 & $79,737,688$ & $97,075,588$ & 4.01 \\
\hline $\begin{array}{l}\text { Social/Recreationa } \\
1\end{array}$ & $61,799,215$ & 1.32 & $81,574,964$ & $94,361,999$ & 2.96 \\
\hline Other & $1,914,779$ & 1.00 & $1,914,779$ & 689,270 & - \\
\hline TOTAL & $249,562,297$ & & $304,288,367$ & $378,930,363$ & 4.49 \\
\hline
\end{tabular}

Table A3.5. Daily Person Trips per Person Adjusted 1990 and 1995 NPTS

\begin{tabular}{||l|c|c|c|c|c||}
\hline & $\begin{array}{c}1990 \text { Trip } \\
\text { Rate }\end{array}$ & $\begin{array}{c}\text { Adjustment Factor } \\
\text { Diary+Rostering }\end{array}$ & $\begin{array}{c}\text { Adjusted } \\
1990 \\
\text { Trip Rate }\end{array}$ & $\begin{array}{c}\text { 1995 Trip } \\
\text { Rate }\end{array}$ & $\begin{array}{c}\text { Average Annual } \\
\text { Change Rate } \\
(\%)\end{array}$ \\
\hline Work, School & 1.015 & 1.00 & 1.015 & 1.248 & 4.22 \\
\hline Shopping & 0.580 & 1.25 & 0.725 & 0.869 & 3.70 \\
\hline Other Fam/Per Bus & 0.698 & 1.41 & 0.984 & 1.100 & 2.26 \\
\hline Social/Recreational & 0.762 & 1.32 & 1.006 & 1.070 & 1.24 \\
\hline Other & 0.024 & 1.00 & 0.024 & 0.008 & -- \\
\hline TOTAL & $\mathbf{3 . 0 7 9}$ & - & $\mathbf{3 . 7 5 4}$ & $\mathbf{4 . 2 9 6}$ & $\mathbf{2 . 7 3}$ \\
\hline
\end{tabular}


Table A3.6. One-Household-Member Person Trips, Total Person Trips, and Non-Accompany Rate by Trip Purpose 1990 and 1995 NPTS

(Person Trips in thousands)

\begin{tabular}{|l|c|c|c||c|c|c|}
\hline \multirow{2}{*}{ Purpose } & \multicolumn{3}{|c||}{1990 NPTS } & \multicolumn{3}{c|}{1995 NPTS } \\
\cline { 2 - 7 } & $\begin{array}{c}\text { HH Non- } \\
\text { Accompany } \\
\text { Person Trips }\end{array}$ & $\begin{array}{c}\text { Total Person } \\
\text { Trips }\end{array}$ & $\begin{array}{c}\text { Non- } \\
\text { Accompany } \\
\text { Rate }\end{array}$ & $\begin{array}{c}\text { HH Non- } \\
\text { Accompany } \\
\text { Person Trips }\end{array}$ & $\begin{array}{c}\text { Total } \\
\text { Person } \\
\text { Trips }\end{array}$ & $\begin{array}{c}\text { Non- } \\
\text { Accompany } \\
\text { Rate }\end{array}$ \\
& & & & & & \\
Work, School & $62,973,929$ & $82,240,011$ & $76.57 \%$ & $84,974,961$ & $110,115,282$ & $77.17 \%$ \\
Shopping & $27,983,544$ & $47,056,740$ & $59.47 \%$ & $45,996,625$ & $76,688,225$ & $59.98 \%$ \\
Other Fam/Per Bus & $33,237,593$ & $56,551,552$ & $58.77 \%$ & $58,602,172$ & $97,075,588$ & $60.37 \%$ \\
Social/Recreational & $33,166,604$ & $61,799,215$ & $53.67 \%$ & $46,509,286$ & $94,361,999$ & $49.29 \%$ \\
Other & $1,233,007$ & $1,914,779$ & $64.39 \%$ & 356,444 & 689,270 & $51.71 \%$ \\
TOTAL & $158,594,677$ & $249,562,297$ & $\mathbf{6 3 . 5 5 \%}$ & $236,439,488$ & $378,930,363$ & $\mathbf{6 2 . 4 0 \%}$ \\
\hline
\end{tabular}

This analysis was conducted using simple methods with the data available. These calculations might raise as many questions as they have answered. Notwithstanding, this is the first attempt to explain the differences on travel that can be attributed to the improvements in the survey methods. Hopefully more research on the effects of different survey methods will follow. 


\section{APPENDIX 4}

\section{SELECTED STANDARD ERROR TABLES}


This page intentionally left blank.

A4-2 


\section{Appendix 4}

\section{SELECTED STANDARD ERROR TABLES}

The final adjusted weights are used in calculating parameter estimates and their sample variance. The standard error estimates shown in the following tables were obtained using the replicate weight variance formula. Further information on calculating standard errors using this method can be found in Chapter 7 of the January 2004 edition of the NHTS User's Guide (Version $3)$.

The standard errors that are shown in the following tables reflect the sampling error but not the variation in estimates due to some nonsampling errors. Sampling error is due to variability between estimates from all other possible samples of the same size that could have been selected using the same sample design (e.g. variation that occurred by chance because a sample was surveyed rather than the entire household population). Estimates that were derived from any of these different samples would differ from one another. Nonsampling error, which can sometimes be much larger than sampling error, is not measured by the standard error.

The standard error of these estimates can be used to construct an interval around specific estimates. This interval will include, with a given amount of confidence, the true population value. About 68 percent of the intervals, created by subtracting one standard error and adding one standard error to the specific estimate, will include the true population value. About 95 percent of the intervals, created by subtracting two standard errors and adding two standard errors, will include the true population value, and about 99.75 percent of the intervals, created by subtracting and adding three standard errors, will include the true population value. Thus, one can state, with a given percent of confidence (as stated above) that the computed interval will contain the true population value.

An example of how these standard errors could be used is as follows. One may want to 
know the annual person miles traveled per household for social and recreational purposes. The estimate of the total number of annual person miles of travel per household for social and recreational purposes in 2001 is 10,586. The standard error for this estimate, as found in Standard Errors for Table 5, is 282.64. To construct an interval that would include the true population value about 68 percent of the time, one would calculate: 10,586 \pm (1)282.64. Therefore, a 68 percent confidence interval for the true person miles traveled per household, as shown by this data, would be included in the interval 10,303 to 10,869 person miles of travel per person. An interval that would include the true person miles per household about 95 percent of the time would be constructed by solving: $10,586 \pm$ (2)282.64. Hence, a 95 percent confidence interval for the true number of person miles of travel per household for social and recreational purposes is in the interval from 10,021 to 11,151 person miles per household. 
Standard Errors for Table 1

Summary Statistics on Demographic Characteristics and Total Travel, 2001 NHTS

\begin{tabular}{|lc||}
\hline Standard Errors for: & \\
HOUSEHOLDS (000) & \\
All & 3 \\
1 person & 0 \\
2 persons & 2 \\
3 persons & 4 \\
4+ persons & 1 \\
PERSONS (000) & \\
All Persons 5 or older & 391 \\
Under 16 & 202 \\
16-19 & 336 \\
20-34 & 229 \\
35-64 & 106 \\
65+ & 47 \\
All Males 5 or older & 228 \\
All Females 5 or older & 263 \\
LICENSED DRIVERS (000) & 357 \\
All & 237 \\
Men & 287 \\
Women & \\
WORKERS (000) & 524 \\
All & 304 \\
Men & 403 \\
Women & 672 \\
HOUSEHOLD VEHICLES (000) & 1,037 \\
HOUSEHOLD VEHICLE TRIPS (000,000) & 21,552 \\
HOUSEHOLD VMT (000,000) & 1,539 \\
PERSON TRIPS (000,000) 5+ & 60,567 \\
\hline PERSON MILES OF TRAVEL (000,000) 5+ \\
\hline
\end{tabular}


Standard Errors for Table 5

Average Annual PMT, Person Trips and Trip Length by Trip Purpose 2001 NHTS

\begin{tabular}{||lc||}
\hline \multicolumn{2}{|c||}{ Stderr for Avg Annual PMT per HH } \\
All Purposes & 564.13 \\
To/From Work & 97.89 \\
Work Related Business & 263.74 \\
Shopping & 105.47 \\
All Other Fam/Per Business & 173.83 \\
School/Church & 47.19 \\
Social and Recreational & 282.64 \\
Other $\quad$ Stderr for Avg Annual Person Trips per HH \\
& 14.33 \\
All Purposes & 4.14 \\
To/From Work & 2.41 \\
Work Related Business & 6.26 \\
Shopping & 7.08 \\
All Other Fam/Per Business & 4.46 \\
School/Church & 7.83 \\
Social and Recreational & 1.17 \\
Other & \multicolumn{1}{c||}{ Stderr for Avg Person Trip Length } \\
All Purposes & 0.16 \\
To/From Work & 0.16 \\
Work Related Business & 2.41 \\
Shopping & 0.14 \\
All Other Fam/Per Business & 0.19 \\
School/Church & 0.11 \\
Social and Recreational & 0.29 \\
Other & 8.51 \\
\hline \hline
\end{tabular}


Standard Errors for Table 6

Average Annual VMT, Vehicle Trips, and Trip Length

by Selected Trip Purposes

2001 NHTS

\begin{tabular}{||lc|}
\hline \multicolumn{2}{|c|}{ Stderr for Avg Annual VMT per HH } \\
All Purposes & 200.79 \\
To or From Work & 69.73 \\
Shopping & 50.29 \\
Other Fam \& Personal Business & 88.60 \\
Social and Recreational & 126.22 \\
$\quad$ Stderr for Avg Annual Vehicle Trips per HH \\
All Purposes & 9.66 \\
To or From Work & 3.85 \\
Shopping & 4.24 \\
Other Fam. \& Personal Business & 5.05 \\
Social and Recreational & 3.95 \\
Stderr for Avg Vehicle Trip Length & \\
All Purposes & 0.09 \\
To or From Work & 0.12 \\
Shopping & 0.10 \\
Other Fam. \& Personal Business & 0.15 \\
Social and Recreational & 0.27 \\
\hline \hline
\end{tabular}


Standard Errors for Table 9

Total Person Trips by Mode of Transportation and Trip Purpose 2001 NHTS

(millions)

\begin{tabular}{|c|c|c|c|c|c|}
\hline \multicolumn{6}{|c|}{ Standard Errors } \\
\hline & Private & Public Transit & Walk & Other & Total \\
\hline Total & 1,562 & 203 & 482 & 291 & 1,595 \\
\hline To or From Work & 439 & 99 & 90 & 45 & 444 \\
\hline $\begin{array}{l}\text { Work Related } \\
\text { Business }\end{array}$ & 252 & 34 & 53 & 48 & 259 \\
\hline $\begin{array}{l}\text { Family and } \\
\text { Personal Business }\end{array}$ & 1,128 & 104 & 277 & 97 & 1,165 \\
\hline School/Church & 434 & 60 & 140 & 170 & 474 \\
\hline $\begin{array}{l}\text { Social and } \\
\text { Recreational }\end{array}$ & 772 & 72 & 328 & 141 & 882 \\
\hline Other & 103 & 24 & 38 & 42 & 133 \\
\hline
\end{tabular}


Standard Errors for Table 16

Average Vehicle Occupancy for Selected Trip Purposes

(person miles per vehicle mile)

2001 NHTS

\begin{tabular}{|ll||}
\hline \multicolumn{2}{|c|}{ Standard Errors } \\
To or From Work & 0.006 \\
Shopping & 0.020 \\
Other Family or & 0.019 \\
Personal Business & \\
Social and Recreational & 0.029 \\
All Purposes & 0.010 \\
\hline
\end{tabular}


Standard Errors for Table 17

Households by Availability of Household Vehicle 2001 NHTS

(thousands)

\begin{tabular}{||l|c||}
\hline Standard Errors for Households with -- \\
No Vehicle & 181 \\
One Vehicle & 311 \\
Two Vehicles & 304 \\
Three or More Vehicles & 250 \\
ALL & 3 \\
\hline \hline Vehicles Per Household & 0.0063 \\
\hline
\end{tabular}


Standard Errors for Table 20

Number of Household Vehicles and Average Vehicle Age by Vehicle Type 2001 NHTS

\begin{tabular}{||lc||}
\hline \multicolumn{2}{||c||}{ Standard Errors for Vehicles (000) } \\
Total & 672 \\
Auto & 644 \\
Van & 248 \\
Sport Utility & 309 \\
Pickup & 358 \\
Other Truck & 67 \\
RV/Motor Home & 71 \\
Motorcycle & 151 \\
Other & 88 \\
Standard Errors for Avg Vehicle Age \\
Total & 0.047 \\
Auto & 0.060 \\
Van & 0.082 \\
Sport Utility & 0.078 \\
Pickup & 0.096 \\
Other Truck & 1.107 \\
RV/Motor Home & 0.457 \\
\hline \hline
\end{tabular}

Note:

- Standard errors are generated for number of household vehicles and average vehicle age, not on percentage of household vehicles and vehicle age. 
Standard Errors for Table 22

Average Annual Miles per Vehicle by Vehicle Age

(Vehicle Owner's Estimate)

2001 NHTS

\begin{tabular}{||ll||}
\hline Standard Errors for Vehicles \\
0 to 2 years & 173.46 \\
3 to 5 years & 127.39 \\
6 to 9 years & 153.40 \\
10 or more years & 107.24 \\
ALL & 420.99 \\
\hline
\end{tabular}


Standard Errors for Table 23

Average Annual Miles per Licensed Driver by Driver Age and Gender (Self Estimate)

2001 NHTS

\begin{tabular}{|c|c|}
\hline \multicolumn{2}{|c|}{ Driver Age } \\
\hline \multicolumn{2}{|c|}{ Stderr for ALL } \\
\hline 16 to 19 & 380 \\
\hline 20 to 34 & 237 \\
\hline 35 to 54 & 125 \\
\hline 55 to 64 & 211 \\
\hline $65+$ & 119 \\
\hline ALL & 93 \\
\hline \multicolumn{2}{|c|}{ Stderr for Men } \\
\hline 16 to 19 & 631 \\
\hline 20 to 34 & 345 \\
\hline 35 to 54 & 227 \\
\hline 55 to 64 & 362 \\
\hline $65+$ & 174 \\
\hline ALL & 147 \\
\hline \multicolumn{2}{|c|}{ Stderr for Women } \\
\hline 16 to 19 & 340 \\
\hline 20 to 34 & 222 \\
\hline 35 to 54 & 115 \\
\hline 55 to 64 & 198 \\
\hline $65+$ & 110 \\
\hline ALL & 91 \\
\hline
\end{tabular}


Standard Errors for Table 25

Number of Workers by Usual Mode 2001 NHTS

(thousands)

\begin{tabular}{|lc||}
\hline Mode of Transportation & Stderr \\
All Modes & 626 \\
Auto, Truck, Van, or Utility Vehicle & 622 \\
Public Transit & 197 \\
Walk & 159 \\
Other & 103 \\
\hline
\end{tabular}

Note:

- Standard errors are generated for number of workers by usual mode, not on percentage of workers by usual mode. 
Standard Errors for Table 29

Daily Travel Statistics by Weekday vs Weekend 2001 NHTS

\begin{tabular}{||l|cc||}
\hline Standard Errors for Daily Travel Statistics & Weekday & Weekend \\
Vehicle Trips per Driver & 0.014 & 0.031 \\
$\quad$ Daily Work Trips & 0.009 & 0.008 \\
$\quad$ Daily Non-Work Trips & 0.015 & 0.028 \\
VMT per Driver & 0.381 & 0.492 \\
Average Vehicle Trip Length & 0.106 & 0.185 \\
Average Time Spent Driving (in minutes) & 0.394 & 0.649 \\
\hline Person Trips per Person & 0.016 & 0.036 \\
PMT per Person & 0.660 & 1.406 \\
Average Person Trip Length (5+) & 0.158 & 0.340 \\
\hline
\end{tabular}


This page intentionally left blank. 


\section{APPENDIX 5}

\section{DIFFERENCES IN METROPOLITAN AREA DEFINITIONS BETWEEN 1983 AND 1990 NPTS}


This page intentionally left blank.

A5-2 


\section{Appendix 5 \\ DIFFERENCES IN METROPOLITAN AREA DEFINITIONS BETWEEN 1983 AND 1990 NPTS}

Between 1983 and 1990, the United States Office of Management and Budget changed the definition of a Metropolitan Statistical Area (MSA). This change complicates any comparisons of metropolitan area data from the 1983 and 1990 NPTS. In 1983 all areas were divided into combinations of counties called Standard Metropolitan Statistical Areas (SMSAs), with the exception that SMSAs in New England consisted of cities and towns. Typically, metropolitan areas are redefined following each census, resulting in additions or subtractions of counties, New England towns, and central cities. Substantial changes were made following the 1980 Census because of considerable revisions in the standards used by the Office of Management and Budget to define the areas.

By 1990 the term "metropolitan statistical area" (MSA) replaced "standard metropolitan statistical area" (SMSA). An optional two-tiered metropolitan structure was introduced for MSAs of a million people or more. These MSAs could be subdivided into Primary MSAs (PMSAs) if certain decentralization conditions were met and if the locality desired such subdivisions. If PMSA's were defined within an MSA, then the MSA became a Consolidated MSA (CMSA).

Of the 318 preexisting SMSAs, 53 became PMSAs within 15 CMSAs, and 8 new PMSAs were established within these CMSAs. In addition, 5 preexisting SMSAs became CMSAs which were further subdivided into 10 PMSAs. As the result of these redefinitions, there were 20 CMSAs with 71 component PMSAs when the 1990 NPTS was conducted. Among these 20 CMSAs, there were ten with a population of more than 3 million. These ten CMSAs were made up of 48 PMSAs, most of which did not by themselves have a population more than 3 million. Moreover, there was one MSA in 1990 with a population of more than 3 million.

In the 1990 and 1995 NPTS, the variable MSASIZE was given a population size value based 
on its MSA or CMSA size. Therefore, if a household was located in an area within a PMSA of less than 3 million, but its CMSA had a population of more than 3 million, then the household was categorized as being located in an MSA of 3+ million. In 1983 and all previous NPTS surveys, however, only the SMSAs which by themselves had a population of more than 3 million were categorized as being "3+ million." The implication of this definitional change on the NPTS data is that many more households were estimated by the 1990 and 1995 data as being located within metropolitan areas with a population of more than 3 million than that estimated by the previous NPTS surveys. 